IRFL-R6

\title{
EXPERIMENTAL STUDIES OF
} IONOSPHERIC PROPAGATION AS APPLIED TO

THE LORAN SYSTEM

II APRIL, 1944 National Bureau of Standards

Washington, D. C. 

Organized under Jolnt U.S. Communication Board

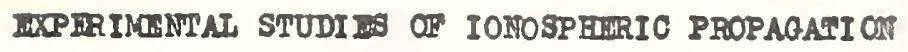

AS APPLIED TO THE LORAN STETIM.

\section{Dontente}

I. Introtuction.

The use of ground wares in the Ioren agtom

Showave t1me-difference measurements.

The sky-were delay.

Corrections for shmme time-difference messnrements. Purpose of those stadiea.

II. Program of observations. Scopo of invertigation.

Lom f requenoy oblique Incidence.

Regulas Loran-frequency oblique incidence.

Refalar Loran-f requenej vortical incidence.

III. Discuselon of results.

A. Low Prequenc obliqu Lncldence.

Skginave pulse pattorne.

Tariaticn in aky-wave timo-d1fierenco mearrements.

Istlmatod accuracy of meawromont.

B. Regular Loran-fronuency obl1que inoldence.

Ground-neve timo-difforenes mamuroment.

If thated sccuracy of mearurement.

\$ky-w8re pulse patteras.

Continuous sh-พaro delag moaurenents.

Randow gky-mate deIay mearureñento.

Skywrave correctlon' measurenent.

Daytlme sky-kave dolay ourvo.

Night time ekghrove deley curve.

Obe of the ky-rave delay curves.

Parlation in sky-woro delay.

Tarlation in skinavo correction.

Alernato meawrement of okj-wave delay from two Loran ntat1 ors.

Equivalont rollection kelghts for deg and night cosdit1ons.

O. Rogular Loran-frequency vortical incidenco.

Relat1on botweon vertical and obliquemincldence skg-rave

transmission.

II. Conclus10zs.

Rellablitty of akyamare receptlow.

Lajer lestght dera.

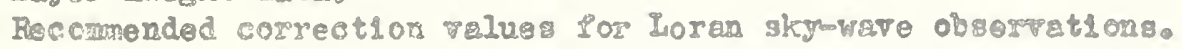

Farlations in sky-bere delay realting from conditlons in the

Ionornhase.

Advantage to be obtalned by ue of lovor rado Irogronclea.

V. Further work noaded. 


\section{Introduct10n}

The Ioran system, as an to narlgation, depende upon the determination of the difference in the great-circlo distances botwoen the point of observation and two polnts of lanown latitude and longitude. By expreseing these distances in units of time (microsecands) required for the ground wave to travel from each of two synchronized radiom requency pulse transalterg to the polnt of observation, the difference in the distances may be deterisined by moavuring the difference in the time of arrival of the two sets of ground-ware pulses. The Loran system is thus fundamentally a groundurare syekem. The difference in the time of arrival of the ground-wave prarses. from the two Loran tranemitting stations, is lenown ac the "ground-wave tine difference".

The direct dotormination of ground-vare t1me differences $1 \mathrm{~s}$ 11mited to the area in which the ground wave from both Ioran tranenitters can be recolvod sufficientis well to permit time-difference mosurements. Pulces roflected frow the lonosphere, or "skg-wave" pulses, may be rem colved at distances conelderably in excese of the ground-wate range. This condition provides a mothod by which the usefulness of tho syotem can be extended, under lavorablo conditions, to distances of approxleately 1,400 natical alles from the farthont transmitting otation.

Two typos of okj-rete timo-d1fferance meacurements are prectical: (a) the difference in the time of arrivel of the firet aicy wave from one station and the ground vare from the other, and (b) the difference In the time of arrival of the firet skg vere from each statjon.

The time required for a kg wave to travel from the transmittine atation up to the lonosphore and back down to the recelving point is greater then that required for a ground wave to travel between tho sane pointi. The difference in the time of errleal of the eky-wave paise and the ground-wave pulse from a alnglo Loran trangmitting station 10 know as the "akghware delay." The magnitade of the skymvare delay is anction of the distance botwen the transmitting and recolving polnts and conditions exiating in the 1onosphere.

In order to represent the difference in the greatacircle distafic botween the Loran tranemitting tations and tho receiving point, all timo-difference mosuremente involving sky waves wust be canverted into equivalent ground-ware time differences. The correction nocessary for a time-difference meesurement between a ground wave and a sky wave is 1uply the sky-wave deley. The correction for time-difference measurgment between two sky waves is the difference between the two sky-ware delajs. These corrections are more fulls explained in connection with the uee of tho skg-wave delay curves. 
The purpose of these tudies was to determines

(a) The rellablilty with whlch oky wares, eultable for Loran eseraremente, can be recolvod at varlove distances.

(b) The effoctivo laver holghte.

(e) Beasonable correction velues to bo aplied to timedifference measuremente Involving igy wave in order to convert them into oquivalent groundwere tim differences.

(d) Tho rexiation in shpware correct1ons that may reasonably be oxpected a resalt of changlng fonopphere conditions.

(o) The effoct of frequency upon ely-ware Loren propegat1on.

\section{Prograx of Observations}

Tho progran consisted of time-differsnce measurenents, from palse trengulasions, 1nvolving ground and ky waves at both rertical and obl1que 1nc1dence. Most of the aeasurements were ade at the I rocolving tation at Sterl1nG, Pa. nohr Wablngton, D.C. llang were made at a temporary observing location at longport. HoJ. A total of 13.774 obeervat1ons vero made durlag the nonthe of October, Forembor. and Docomber, 1943, and January. 1944. \& tandard Ioren rocolver and

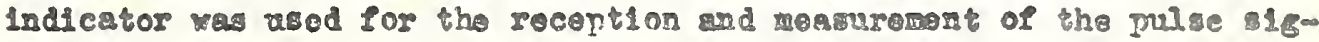
nels.

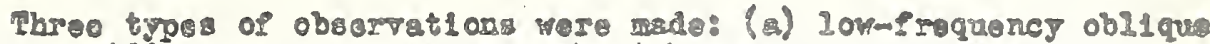

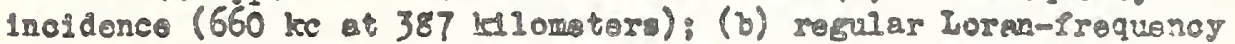
oblique incldence at parloue distances up to 1500 Hlometers. (c) regular Ioran-1roqueney vartlcal Lxeldonoo.

Low-frequency $(660 \mathrm{kc})$ observations were made on palse trans-

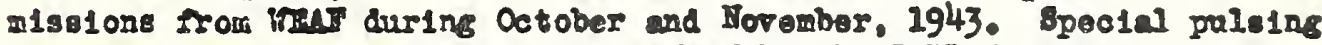
equlpaent was furnished to atation Whe by the IRPL for this puxpose. The transmiselone wore made during the flrst ton minutes of each half hour. beginning at 0030 and ending at 0410 local time. This phase of the progrem involved messuremonts of the dilforonce in the tine of arrivel of the flret le ware and the gand wave. The distance botwoen the trengitting and recelving polnts was 387 kilowoters.

Pulse transmissions wero also obeerved Prom VIV (700 ke, $591 \mathrm{~km})$

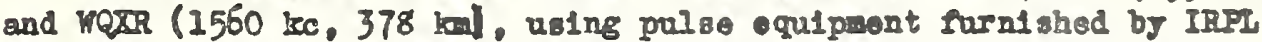
for the purpose. Howerer, entlafactory receptlon of transmiselon from VIV was found to be 1 mpractleal beonuse of interference on adjecent

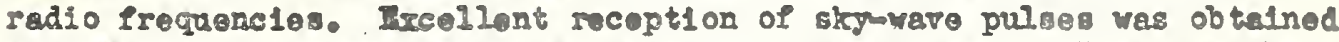

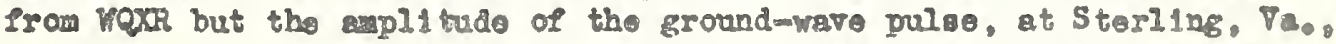
was too gill to porrit direct mossurement of gky-wave dolay valuom. 


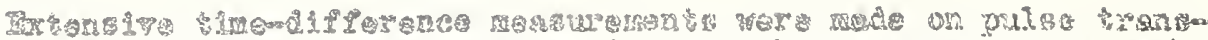

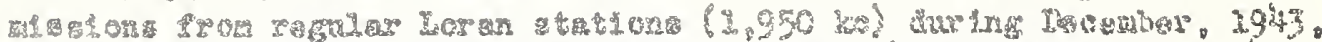

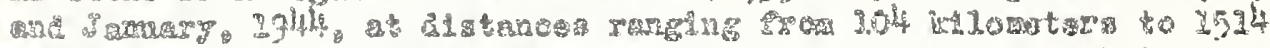

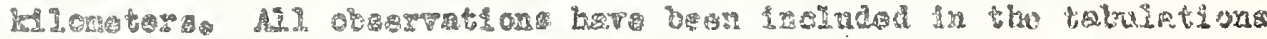

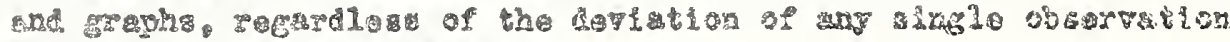
fy

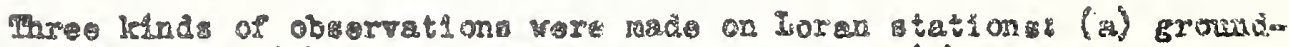

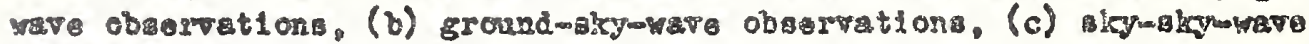
observat1 ons.

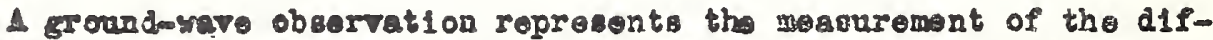
ferenco in time of arrival of the ground waro srom each of two Ioren station. Mose masurement are usorul for comparison with the calm

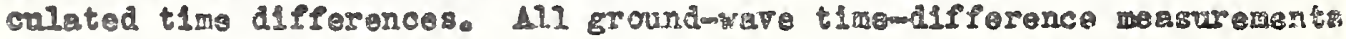
were made from the leading odge of cne ground-weve pulse to the lerdias adge of the othor.

A ground-eky-wave observation represents the mosurement of the difference in the time of arrival of the ground ravo from one Loran station and the flret gky wave from the othor. Tha skywavo dolay is the difforence botween this measurement and the froundmave time difforence. 111 ground-oky-yave time-difference measurements vere iade from the leading edge of the ground-wave pulse of one station to the learling adge of the first skJware pulse of the othor stetlon.

$\Delta$ elomskgnaro observation repreants tho difforence in the tire of arrival of the firat oky wave from oach of two loran transmitting atet1ans. The diference botween this mesouremont and the groundwave timo difference is bown es the "oky-orave correction" and 18 the difforence between the lcy-wave delays of the two algnals. All sky-sky vere tiai-difference measurements vere made from the leading odgo of the flrst shomare pulso of one station to the lending odge of the first sky-rave pulse of the other station.

Tandom mearurements, of the types rectlonod above, were made on thres palrs of Loren atationis. as follows

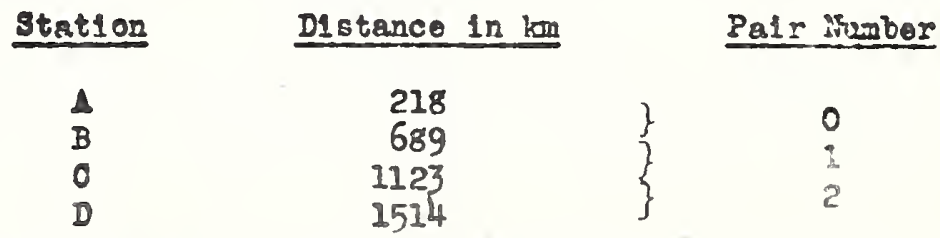

Thas observations were mado at the IRPL recolving station, Steriling. Pa, be troes 0830 and 1530 local time.

Two sets of continuous ground-8:y-wero observations we ne nalintalned, at the rato of one reasurement war minut, over a 24 horre parlod. for sach of thres disteisces as follows: 


\begin{tabular}{|c|c|c|}
\hline $\begin{array}{l}\text { Roceiving } \\
\text { Iocation }\end{array}$ & $\begin{array}{l}\text { Distance to Tranamitting } \\
\text { 8tation in lon } \\
\end{array}$ & Date \\
\hline 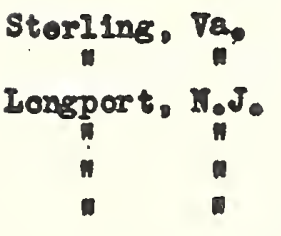 & $\begin{array}{l}689 \\
689 \\
442 \\
442 \\
885 \\
885\end{array}$ & $\begin{array}{l}28-29 \text { Dec., } 1943 \\
29-30 \text { Doc. } 1943 \\
18-19 \text { Jan. } 1944 \\
20-21 \text { Jan. } 1944 \\
19-20 \text { Jan. } 1944 \\
21-22 \text { Jan. } 1944\end{array}$ \\
\hline
\end{tabular}

Random ground-wave obervat1ons were medo at Irongport, H.J.o for conparison wth ealculated tino difforences.

Heasuroments of ky-mare dolay $(1,950 \mathrm{ko})$. at rertloal inoldonoc wore inde at the Rational Buroau of Standards radio recelving tation. Sterling, Va, durlue Docomber, 1943.

\section{Dlecuselon of Romelts}

\section{Iow-Irequenor Obl1queme1dence}

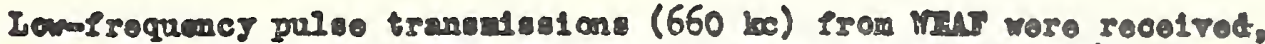

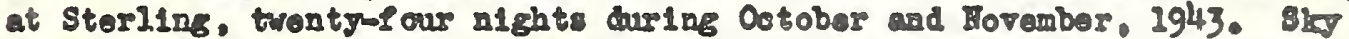
vares were presont at all tlaes during the observational per10d, 0030 to 0410 looal tino.

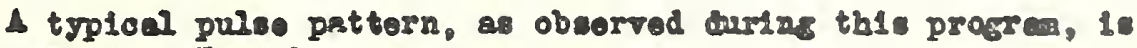
illustreted in Fis. I.

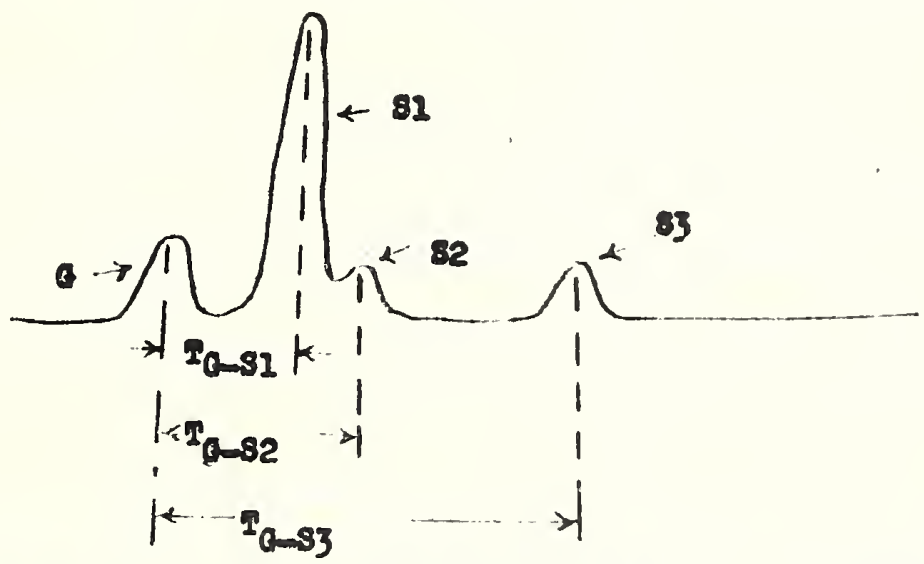

P1g. 1. Typical pulse pattoms rocelred from MN. 
B. Begular Ioran-Iroquency Obl1que Incidance

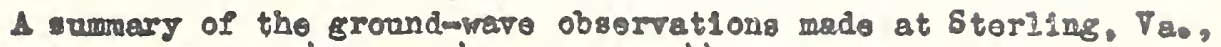
botoon 8 Docember 1943 and $14 \mathrm{January} 19441 \mathrm{~s}$ hom in Tablo 1.

Tho firet number in the Ioran roading ldantilies tho Loran a tar

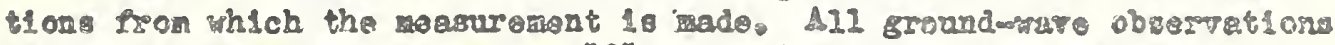

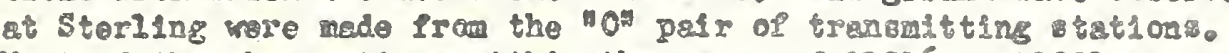
Host of the observetion winin the ranco of 01216 to $01221 \mathrm{ser}$ ob

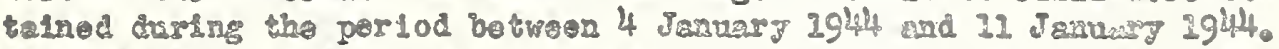

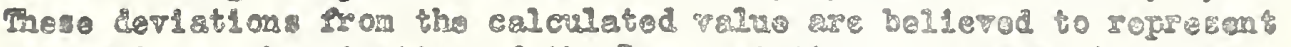

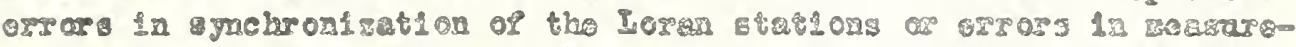

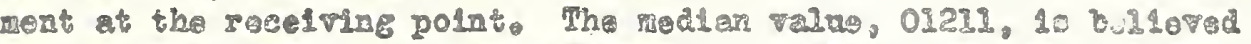

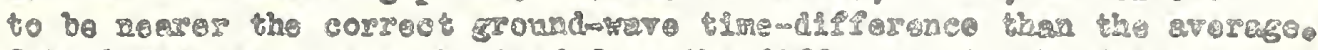

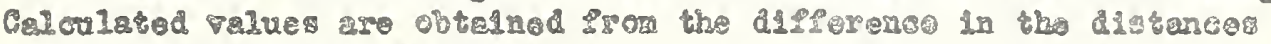
to the trasalting ctation:。

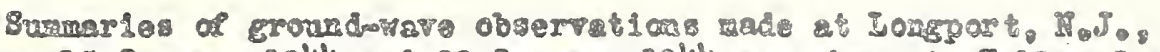

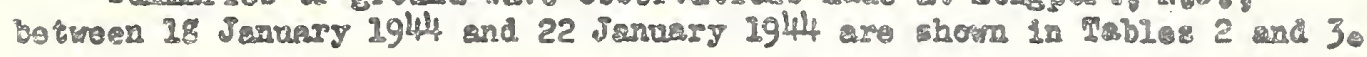

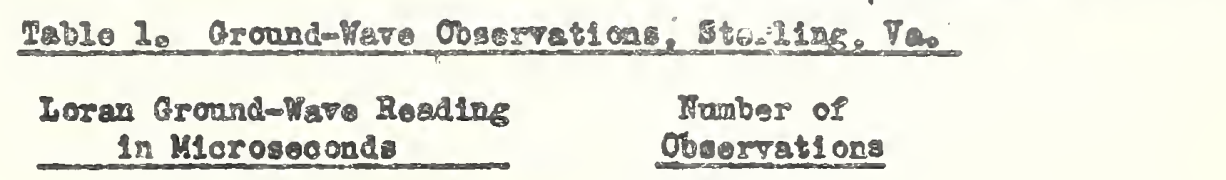

01202

01203

01206

01207

01208

01209

01210

01211

01212

01213

02214

01215

01216

01217

01218

01219

01220

01221

01222
2

2

4

4

13

52

138

178

24

51

38

20

21

22

23

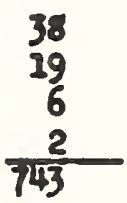

Average ground-were time difforence, 01212.3. Median groundwavo tire alferenco, 01211. Q lenlatod sroundfrave tive differcence, $01210,6$. 
Fab10 2. Ground-Have Observat1 ons, Longport, Noto

Loran Around-Kave Resding in Mler oseconds

01642

01645

01646

01647

01648

02649

01650

01651

01652

01653

01654
Rruber of Obaervations

2

13

25

127

281

205

15
2

1

Average groundware tim dfference, 01649.2

Median ground-wave timo difference, 01649

Oelculated fround-wave time difference, 01647.8

Table 3. Ground-have Observations, Langport, N.Jo

Ioran Grownd-Fievo Rosding

is Meroseconds

13901

13902

13904

13905

13507

Thuber of

Observatioas

13908

1

23909

13910

13911

13912

3

1

2

2

13913

13924

13915

13916

13917

10

23

54

29

13918

13919

13920

14

6

4

1

3

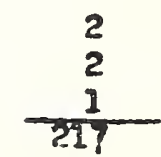

Arsprąs grond-ravo time difforence, 13910.8

Median ground-wave time difforenca, 13911

calculated ground-we time difference. 13911.0 
The swall anount of scatter in the grcundwkave mecarrements as shom in rable 2. relative to the other two eroups, 1e bellevod to be duo to more favorable ground-wave fleld intenglties obtalnod. for those observations.

On the besis of the distribution of ground-wave observations, It is belserad that \pm 2 microsecond is a reasoneble prohable arror for 4

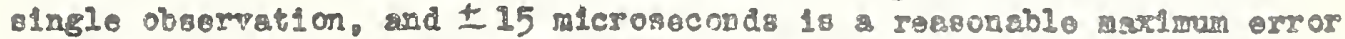
to be expectod Irom a inglo obnervation as a rooult of orroro in ayn-

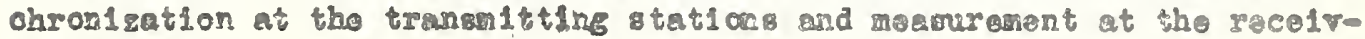
lac point.

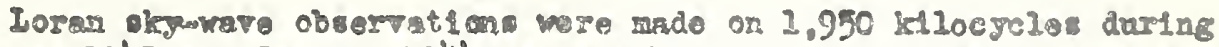
Docmber 1943 and January 1944, at ald houra of the day end night and at distaness of 104, 218, 442, 689, 385, 1123, and 1514 kiloweter from tho transulting tation.

The aplitude of the sy mer wa meh greater at night. ragarclese of distance. than during the MN. Tho woalest thy was wore usually

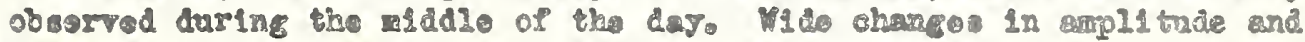

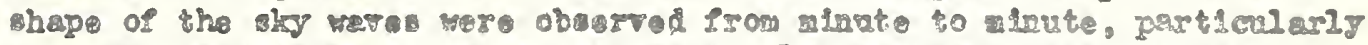

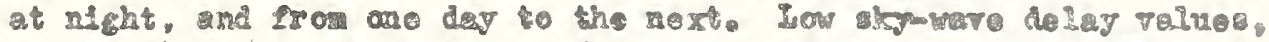

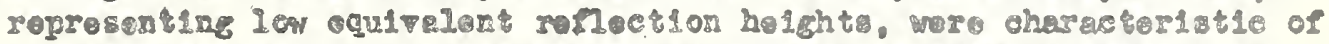

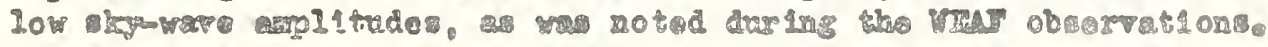

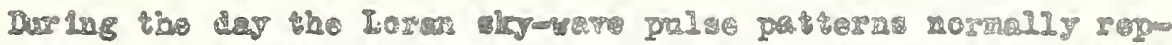

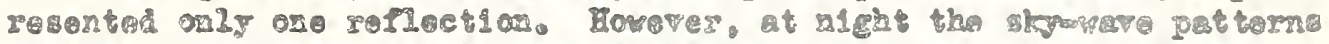

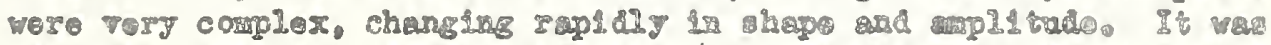

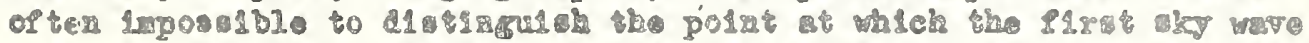

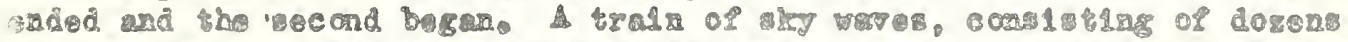

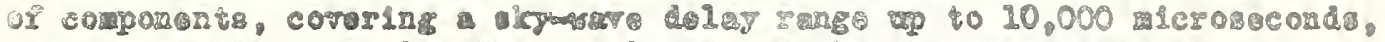

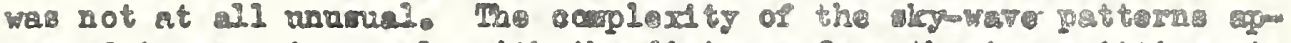

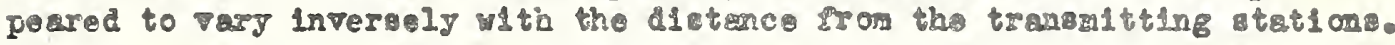

Sug wares fram the Ioren etation located 689 kilanotars from tho polnt of obsorvation were alway present, regardlose of the t1mo of daye Sky waves Ircan the station located 218, 442,885 , and 1123 lellometers Prom tho point of observation rere normally protent at all hours of the dag. Skg waves from the tatton located 151 li bllometors from the point of observation wero always prosent at nlebt and about fifty percent of the time at all hours of the dayo

Three etr of continuou kg-kave delay observations were rade, at the rate of one time-difforance mearement per rinute. Crer two 24-hour porlods asch, at ditances of 442.689 , and 885 k110moters, for the purpose of obsirving any diumal chage in sky-mave delay. The arerage and extreme values, for each 20 minute perlod, obtalned. rou thls program are shom in Figs. 4 to 9. The skywave delay for

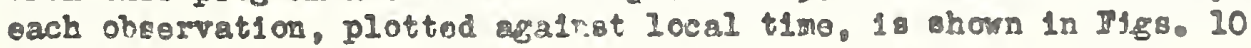
to 33. 
It 111 bo obsorted that the $3 k y$ war delay was nornally loss during the day then at nleht. However, on 29 December 1943. from 0440 to 0620 (F18. 4). and on 21 Jemuary 10,44. frow 0040 to 0140 (F1g. 8). skyurave delay values rere obtalned comparable to those normally measured dtaring the dagtime. An abrupt increase in aky-kave dolay ot or near sunrise was observed on four of the six days of continuone observation.

The ralues obtained frow the continuous observat onal program have been divided into four soups, besed unon the time of observation, as followes

(a) Deytime observations, covering the period 0900 to 1500 locel time.

(b) Sunset observations, covering the perlod 1500 to 2100 local tim.

(c) Nighttwe observat1ons, exvring the per1ed 2100 to 0300 local time.

(2) Sunrise observations, covering tho perlod 0300 to 0900 1ocel t1me.

The distribution of sky-wave delay observations (number of observations v8 sky-wave delag) for each of the above time periods is shown in Figs. 34 to 36.

The distribution of aky-wave delay meesurements, made at rendom during the day, between 8 December 1943 and 14 January 1944 are shown in F1gs. 37 and 36. These measurements wore made at distances of 218. 689. and 1123 k1lomoters from the trenemitting stations.

The distribution of sky-wave correction sbservations, mado at randow during the dar. Irom 5 December 1943 to 14 January 1944, 18 shown In Fig. 40. These observations represent time-difference measurenents involving only sky waves. The sky-wave correction 18 the difference betwoen the skyware delay of each signal and therefore involves the distance from each transmitting etation.

The sky-were deley curve represents the slyyware delay as a function of distance from the trensmitting station. Polnts, oy which this curve may bo determined graphically, are obtalned from skymave delay measurements wich represent the hel int of the delay curve at each chservational distance, The daytime delay curve, 1llustrated in Fig. 39. was derivod in this sanner from the average and median values of all daytime skywave delay asesurements.

So is

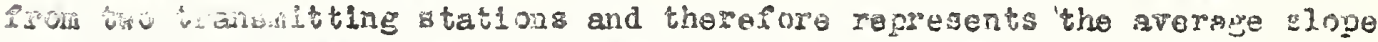

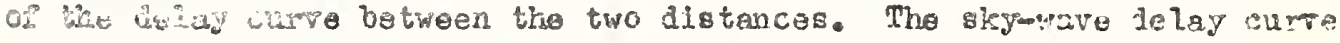
may thus be extended, beyond dietences at which the sley-weve delay 
can be directly mesoured, by use of sk-wave correctlon observations.

Fig. 41 contains the dajtime skpwave delay curve; proviousig described, wh polnts representing the moan and medien of all skmwave correotions observed at distances of 218-589, 689-1123, and $1123-1514 \mathrm{k110}$ moters from transmitting stations.

M16. 42 contains the skymare delay curve, der1red by the Burean of Ships, Navy Dept., for determinati on of Loran skywave corrections. Tho moan, nodian, and oxtreme values of nighttlmo skymare delay obtalned from the continuous observat1onel program are also sham in this Iig. The ranges of observed vaines are sheim by the three rertical 11208. As shown, the nean and modlan observed nighttime values agreo voll wth this curvo. (For daytime values $800 \mathrm{Flg} .39$ ). F18. 42 18 bolleved to sepresent values of sky-nave deley that may reasonably bo erpected under nlght time $10 n 0$ phore condition.

The parpose of the oky-wave delar curve is to enable the observer to convert a Ioran time-ilfforenco moasurement, Involving by waros, into an oquivalent grcundwave time differenco. The nethod by which this mag bo accomplishod v131 bo brlol2y explainod.

Consider a ground-wave measurement as 111ustratod in F18. 43.

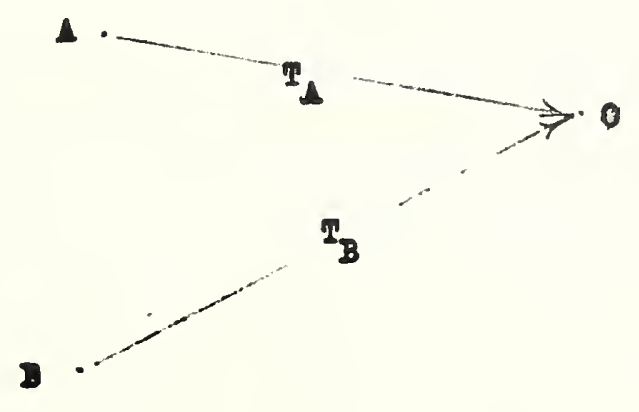

$$
\text { 18.6. 43. }
$$

" $A$ " and "B" reprosent two Loran tranenitting statione and "O" tho point of bbcorvation. T/ represents the time, in microseconds required for a rounderave pulse to travel srom $A$ to $O$ and Th the $t$ ime, in miorom ceconde, for the rounduravo pulso to travol from B to O. If the transaltting stations aro so szachronlzod that the pulses 5 rom B aro transmittod oractly $\beta$ microesconde lator than those from station $\Lambda$, the measured ouna-were timo difforenco $\left(T_{A Q-B Q}\right)$ w11l bo as follows

$$
T_{A G B C}=\beta+P_{B}-T_{A}
$$


This rolation, for ground-war the differencer holds regardles of the postition of $O$ w th reepect to $A$ and $B$ and therefore regardloss of the relative magnitudis of $\mathrm{F}_{\mathrm{A}}$ and $\mathrm{P}_{\mathrm{B}}$

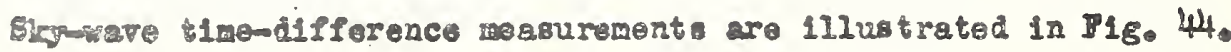

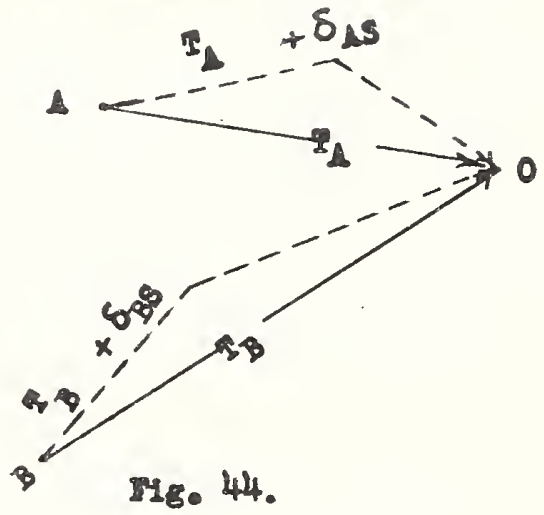

$\mathrm{T}_{\Lambda}+\delta_{\Lambda \mathrm{S}}$ represents the tine requlred for the sirymare pulse to

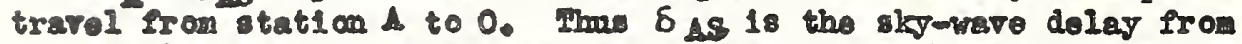
station $A$. $T_{\mathrm{B}}+\delta \mathrm{BS}$ roprosente tho time required for the kgavare pulso from tation B to travel to 0 , and $\delta$ BS 18 tho kymave delay from station $B$.

The three ghware measurements poselble wador this condtion aro:

(a) TAGBS, which representg the difference in the time of arFiral of the ground vare Irom atation A and the elo ware fron tation B. The meacured velue at 0 will bos

$$
\begin{aligned}
T_{\triangle Q-B S} & =\beta+\left(T_{B}+\delta_{B S}\right)-T_{A} \\
& =\left(\beta+T_{B}-T_{A}\right)+\delta_{B S} \\
& =T_{A Q B Q}+\delta_{B S}
\end{aligned}
$$

(b) Tremo, which ropresents tho difference in the time of arm rival of the ground-ware from station $B$ and the ware Pros etetion $A$. The nosured value at 0 will bes

$$
\begin{aligned}
T_{\triangle S-B G} & =\beta+T_{B}-\left(T_{\Lambda}+\delta_{A S}\right) \\
& =\left(\beta+T_{B}-T_{A}\right)-\delta_{\Lambda S} \\
& =T_{A G-B G}-\delta_{\Lambda S} .
\end{aligned}
$$


(o) TAS-BS. which repreaents the differenco in the sky waves from each stat1on. The measured value at 0 w11 bo :

$$
\begin{aligned}
T_{A S-B S} & =\beta+\left(T_{B}+\delta_{B S}\right)-\left(T_{\Lambda}+\delta_{A S}\right) \\
& =\left(\beta+T_{B}-T_{A}\right)+\left(\delta_{B S}-\delta_{A S}\right) \\
& =T_{A Q B G}+\left(\delta_{B S}-\delta_{A S}\right)
\end{aligned}
$$

It 111 be observod that the magnitude of the correction appilcable

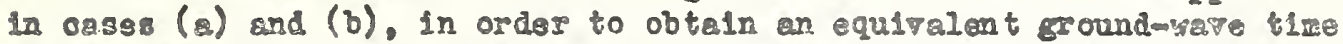

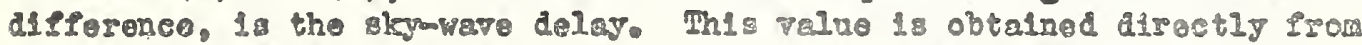
the skyawave colay curpe and is a function of distance from the trane-

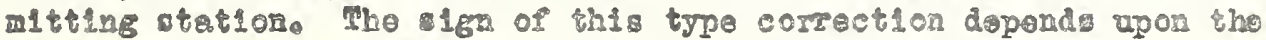
rolative distances Prow tho transultting statlons

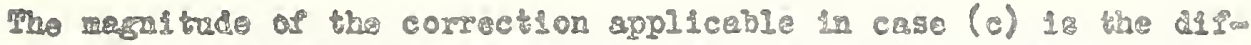
foronce botwen the okg-wave doley of atation A and $B$. Theso raluen

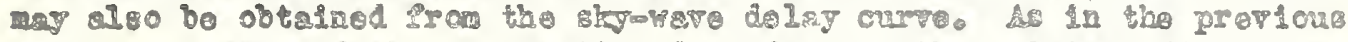

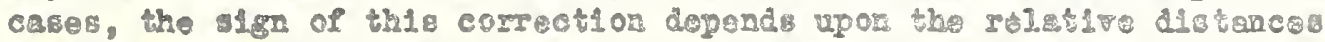

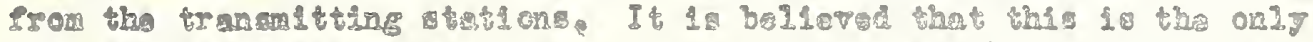

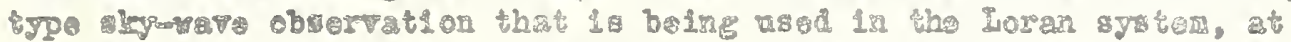

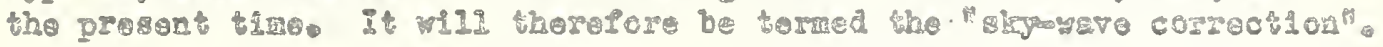

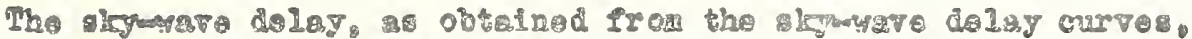

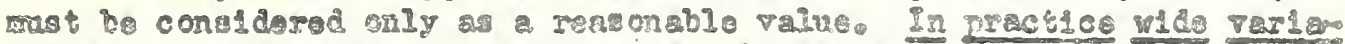

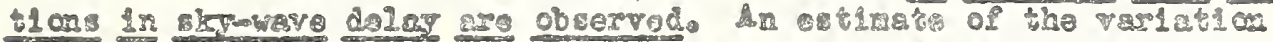

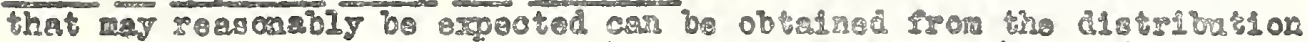

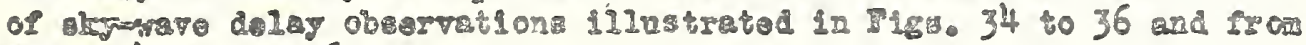
Tablos 4, 5. and 6 .

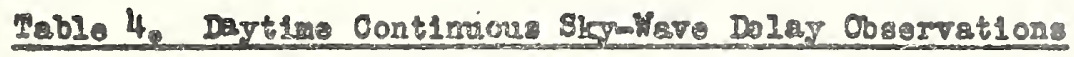

\section{Distance frow tranchitting} ctation. in lallomotor:

Shamare delay obtalned

srom delar curre. In mlerosoconds

Range of $50 \%$ of obsarsatioss II mleroseconde

Total range of observations in microsecomes
442

689

885

118

78

66

109 to 12281 to 8261 to 68

90 to $138 \quad 71$ to 9149 to 75 


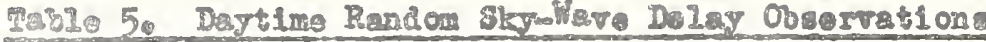

Diotance from transmiting

atotor in kilometers

$228 \quad 689 \quad 1.123$

Sisystere delay obtalnod

2ros das curvo. in

microseconds

243

78

59

Range of $50 \%$ of observatione In microsecende

226 to $256 \quad 62$ to $81 \quad 50$ to 67

Total rango of observations in microacondo

145 to $314 \quad 41$ to $99 \quad 19$ to 205

\section{Table 6. Hightt1es Continuous Skp-Nare Delay Observations}

Distarce from tranant tins

- tat10a, in k1lomotore

Signvere delay obtained

Irom delas curve, in

mlerosenonds

144

442

689

885

Range of $50 \%$ of observations,

in microseconds

141 to 15091 to 10199 to 86

Total range of observation.

In mieroseconds
109 to 18173 to $113 n$ to 98

If the sky-ware deley Ir qa one Loran atation varlea independontIy from the hymave dolay of the other. nomewhat wider variations in the akgurave correction would be expected for a Loren time-differanco meacurement between two sky weres than for olther of the skymave delay separately. However, tho obsorvod skgware correction ralues, mado during the dartime, have approxtmately the same range of ralues as the corresponding skgure dolay moavrements mado during the eamo portod.

The diatribution of akymave correction ralues obtalned from

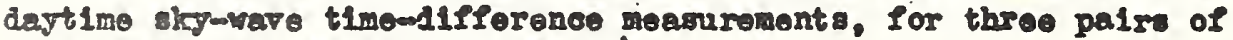
Loran stations, is show in Fig. 40.

Aternate usasurements of akpuraro delay were mado, for short perlods. on stet1ons at distances of 104 and 442 stlometers and at lit2 and 855 Hiomotor. Equivalont rolloction holghts woro dotorminnd tram the symaro dolay ralue and plottod agalnst time of day. Iige. 45 and 46 contaln this information. 


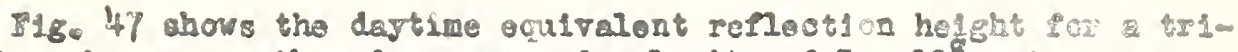

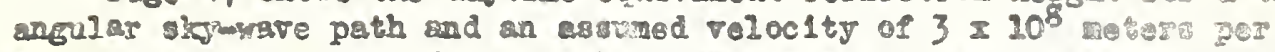

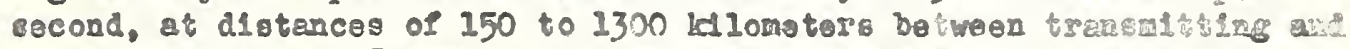
rocolving points. Those are the oquivalont rollection helghts or the daytlmo skT-Mavo delog ralue of Y18. 39.

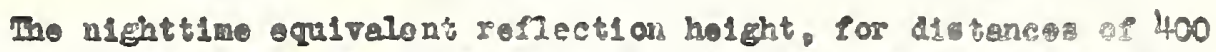
to 1300 kllomoters botwoen transulting and recolv1ng polnts whob

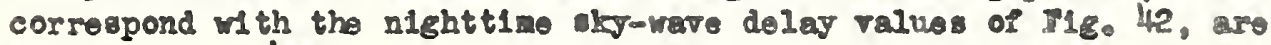
shom in Fig. 48.

\section{- Regular Loranorrequener Voatical Inol donce}

Meavurementa of vertical-1neldonce pulve tranmaleslars vere made at a Prequenoy of $1,950 \mathrm{kc}$. The virtuel bolght obtalned ranged between 98 and $130 \mathrm{kllaneters}$ and vere in vubetantlal acreament with the regular rork1cal-1ncldonce 10nosphore rocords mado furing the som perlod at Sterling.

A thorough disoussion of the relationship botwoen rertical-

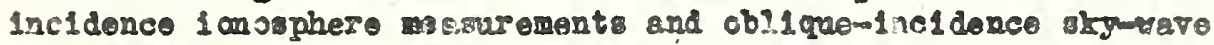
transwialion is contalized in the paper. The relation of radio skyware

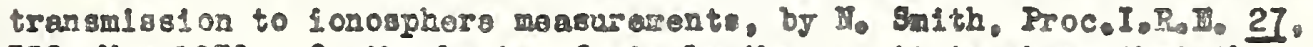
332: May 1939. On tho basis of ataple theory. It 1s uorn that tho virtual bolght of rollection, moanured at vertical incldence, for a radio frequency 1.1 equal to the holght of the oquivalont triangular

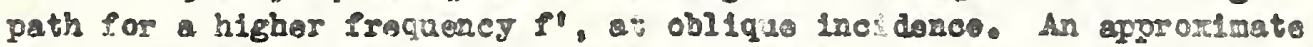
rolation hetwesn these requonclas, corrected ore tho curveture of tho earth. 13 given as follows:

$$
I=e^{\prime} \cos \phi_{0}\left[1-\frac{z_{L}-z_{0}}{R+b} \tan ^{2} \theta_{0}\right]
$$

Mere: the angle $\phi_{0}$ and distasces $A, h, z_{v}$, and $z_{0}$ are those indicated in F18. 49.

Th1s approrimation lomd to results good so 1 percent or botter

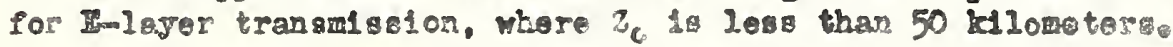

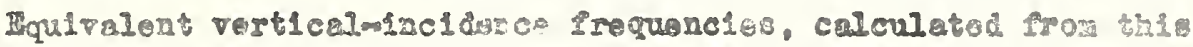

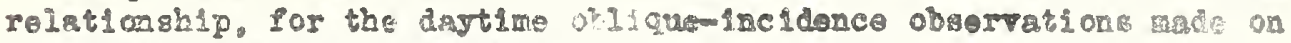
$1.950 \mathrm{ko}$ ars abnwr. 1n Table 7.

Iquivalont vertical-inclence Iroquonctes, calculatod from tho nightime obliquonciaenco deta, ro shown in Tablo 8.

The quitrient rofleotion hoighto are plotted agalnat oqulfalont

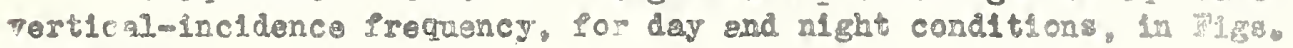
50 and 51. 


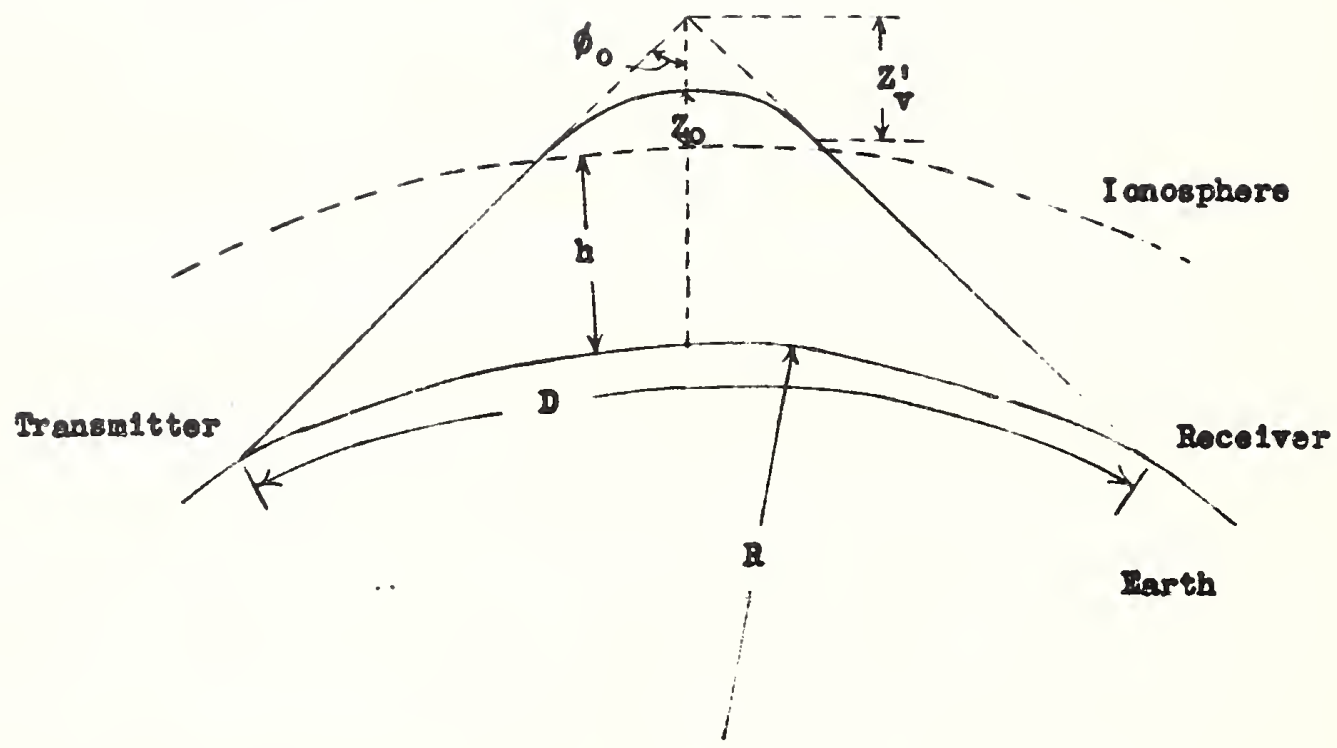

$D=$ distance of tranumiselon, $R=$ radius of the earth, 2! bolght of equivalent triangular path In the ionosphere. $z_{0}$ a true helght of reflect10n In the lnoosphere, $b$ a inlmum bolght of lonosphore above the earth. $\phi_{0}$ \& cne balf-rertex anglo of the equivalont triengalar path.

16. 49. 
Table 7. Dart1me Iqu1valent Pertical-Inclaence Frequenoy for 1950-ke Cblique-Incidence Transmissions.

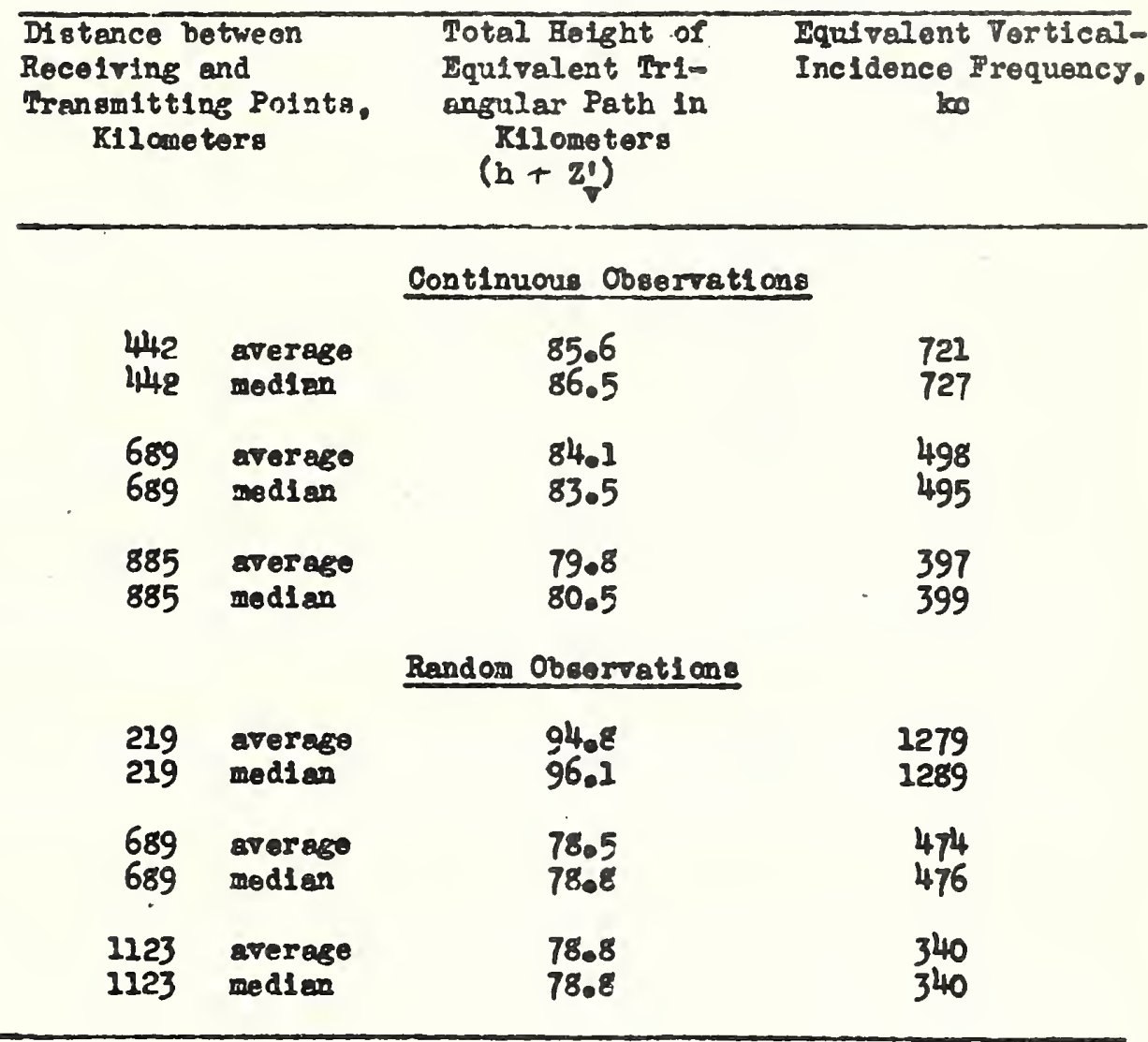


Table 8. N1ghttime Equivalert Vertical-Incidence Fraquency for 1950-ke oblique-Incidarce Transmiarions.

\begin{tabular}{|c|c|c|c|}
\hline \multicolumn{2}{|c|}{$\begin{array}{l}\text { Distance between } \\
\text { Recelving end } \\
\text { Transitting Points, } \\
\text { rilometers. }\end{array}$} & $\begin{array}{l}\text { Total Ioight of } \\
\text { nquivalont Ir } \\
\text { angular Path in } \\
\text { Kilometers } \\
\text { (h+ } 4 \text { ) }\end{array}$ & $\begin{array}{c}\text { Equiralant Porifcal } \\
\text { Incidence Frequency. } \\
\text { loc }\end{array}$ \\
\hline $\begin{array}{l}442 \\
442\end{array}$ & $\begin{array}{l}\text { everage } \\
\text { modian }\end{array}$ & $\begin{array}{l}97.6 \\
97.9\end{array}$ & $\begin{array}{l}806 \\
807\end{array}$ \\
\hline $\begin{array}{l}689 \\
689\end{array}$ & $\begin{array}{l}\text { errerage } \\
\text { modien }\end{array}$ & $\begin{array}{l}91.4 \\
91.4\end{array}$ & $\begin{array}{l}537 \\
537\end{array}$ \\
\hline $\begin{array}{l}885 \\
885\end{array}$ & $\begin{array}{l}\text { arerago } \\
\text { modian }\end{array}$ & $\begin{array}{l}91.6 \\
90.5\end{array}$ & $\begin{array}{l}445 \\
441\end{array}$ \\
\hline
\end{tabular}

The equitalent rortical-incidence frequency for the Whar observot1ons, or $660 \mathrm{kc}, 18286 \mathrm{kc}$ and the equiralent replection helght is 90.5 kiloneters. These values represent the menn of all observations on 660 ke.

Vertical-incidence 10nosphere measurements, in the range of 250 to $800 \mathrm{kc}$, are not, as yet, avallable for checking the virtual height of the oquivalent pertical-incidence frequencles.

\section{Conclusions}

Sicy-wave propegation, with equivalent reflectlos layer heights between 60 and 110 kilometers. may be expected from the present I.oran transmitting stations on $1,950 \mathrm{kc}$, at all times of the night, and approximately fifty percent of the time during the day, at distances of 400 to 1.500 kilometers. The meximum night distance is probably around 2,500 kd lometers.

Data on the 1onosphere layer heights effective in Loran propagation under various conditions and at verious times of day are given in the attached Figs.

Correction values for Ioran slymware observations, as a funetion of alstance from the transmitting stations, may be obtained from the shy-kave delay curves of Flgs. 39 and 42 , which correspond to the exultalent reflection helghts of Figs. 47 and 48.

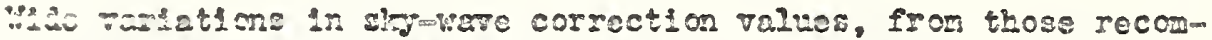

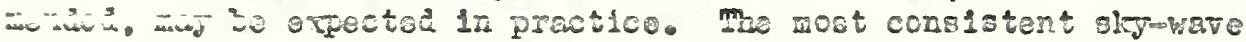

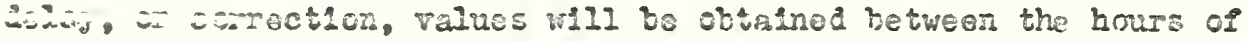

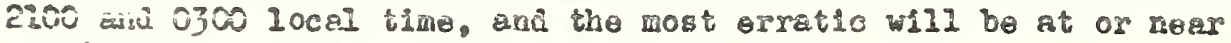
sunrise and sunset. 
Deflat1ons from the recomended sky-vave delay values up to \pm is microseconds mas be expocted at distances from the transiniting oter tions of 500 kllometerg or ETeater. but the probabllity of a single Ioran sky-wave mearurement falling within this range is dependen upon tho time of day and the perticular day on which the observation 18 made as well as the distance from the transmitting statlons. Tnder unneual 10nospheric conditions, the recommended skywave delay values may bo in orror by as mach as 50 microseconds.

It appoars that oubetantial advantages can be gained by the use of lower rad10 frequenc10s than $1.950 \mathrm{kc}$, becenes of al apler

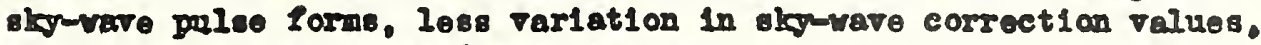
and greater ground-wave di stance range.

\section{Morther Nork Meeded}

The following subjects, In epproximate order of wrency. shenld be otodled. Thog w12I bo paraued as fully as practlcable.

(a) Diurnal rarlation in ebjure correction valnes. Fis will in rolve cont1mous measuraments, over at leant 24 hour porlode. of the time difference between lo weros from both atation in a Ioran palro

(b) Ilternate neasuremente of the elgy-vere delay from two IDran stations. Th1 Information wil how the extent to which the equiralent reflection holght of the two slymware petho vary 1ndopendeotly.

(c) Poriodic contienous measiuremonts of skgware delag. for the parpdse of dotermining ang seasonal trend in equivalent roflect1 on holght.

(d) Hessurament of virtual holcht at equivaleat vorticaluinc1donce irequenc10s. If these neswremente check the values indlcatod

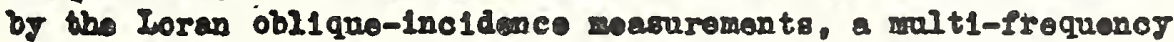
mitorat1c rocording equipment, covarlng tho range of 200 to 600 ldlocyclas oould be used in connection with saltable transalesion curves to obtain obliquo-inc1donce tranamision information at a iniman of time and expense. If the equivelent vertical-ineidence measurements do not chock the valuos Indicated of the Ioren measurements. obl1que-1nc1dence measuroments may bo wad at higher frequencles than $1.950 \mathrm{kc} 10$ order to check the accuracy of the tranamienion ourves now belng ued.

(e) Measurement of ekg-rave dolay for an east and wost path and lor a north and south path. In order to determine the effect of the

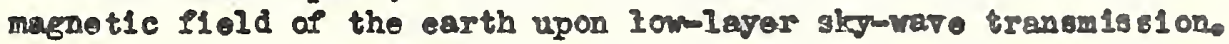

(1) Determination of sky-vare flold Intensities, for correlation with equivalent reflection holghts.

(8) Doterninet1oa of shywave delay at latitudes othar than that of Vashirgton. 



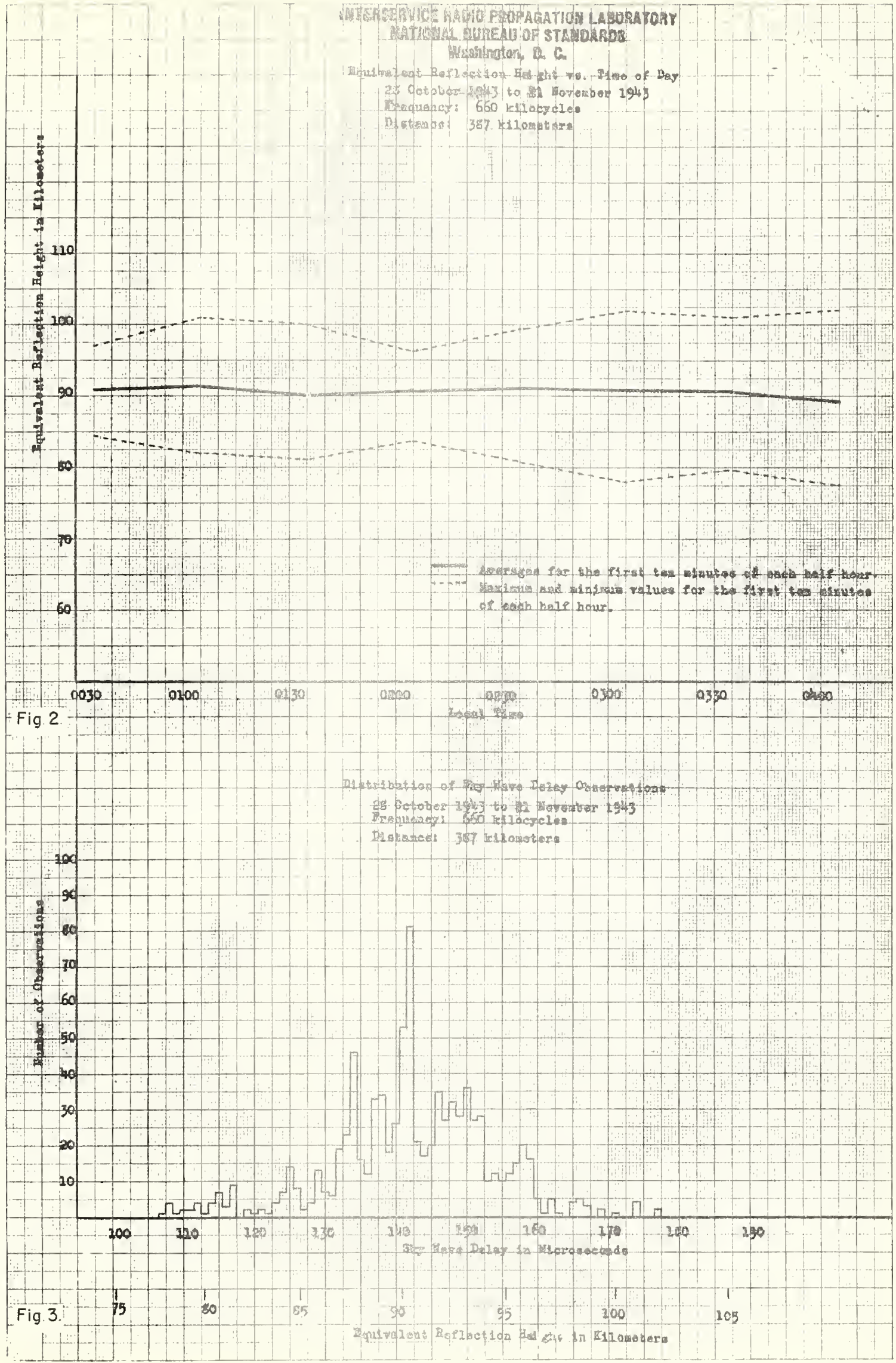




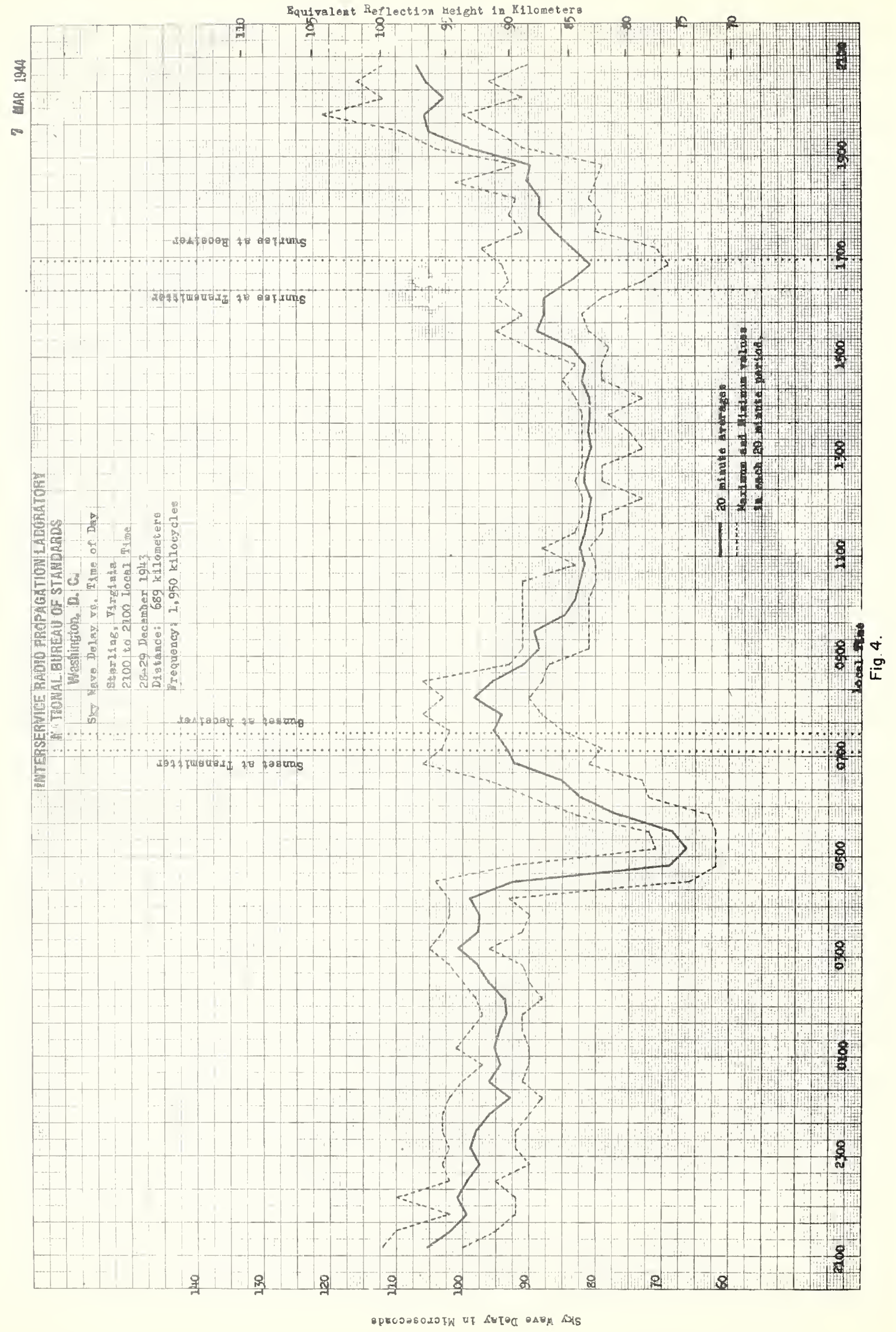




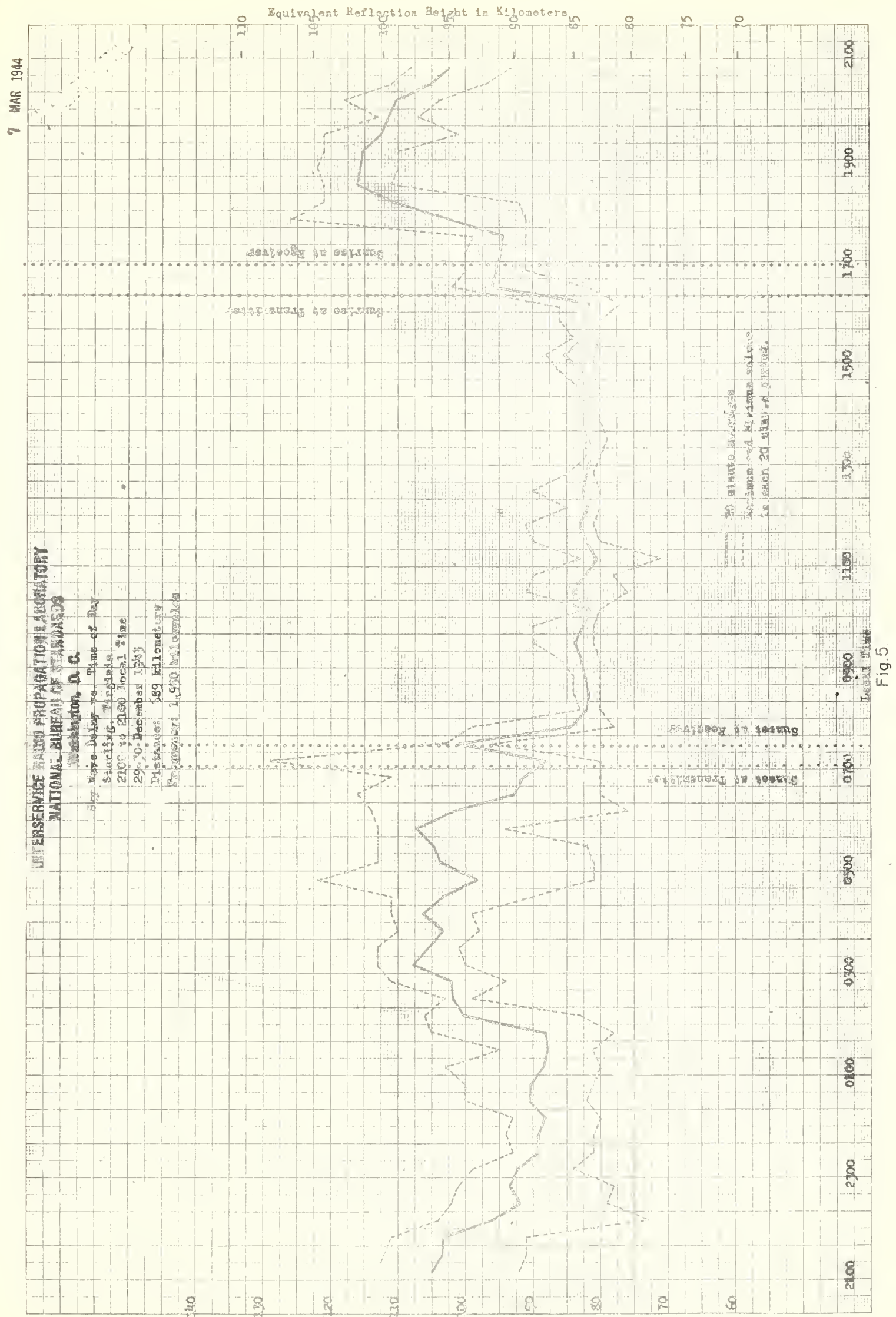




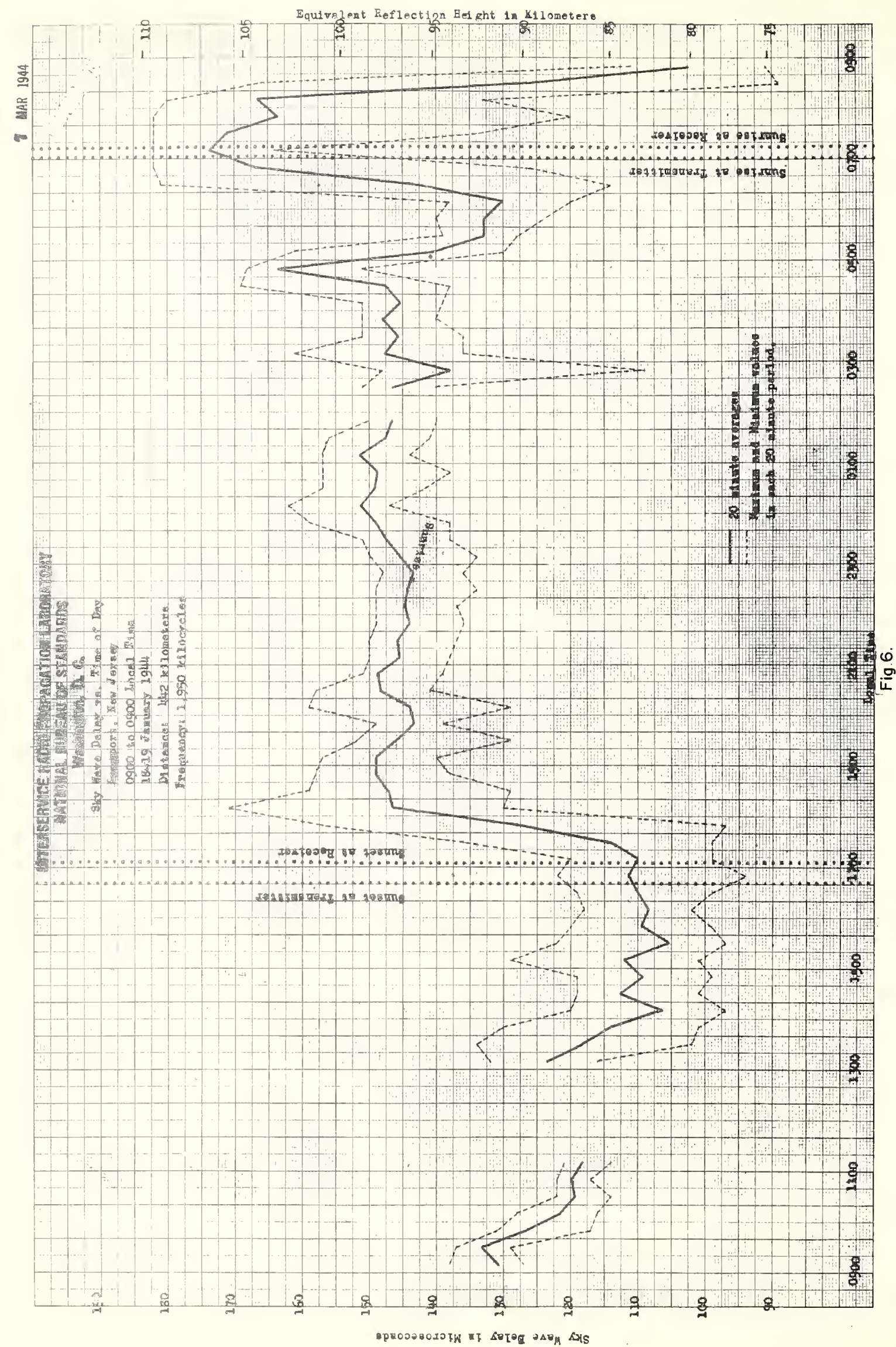




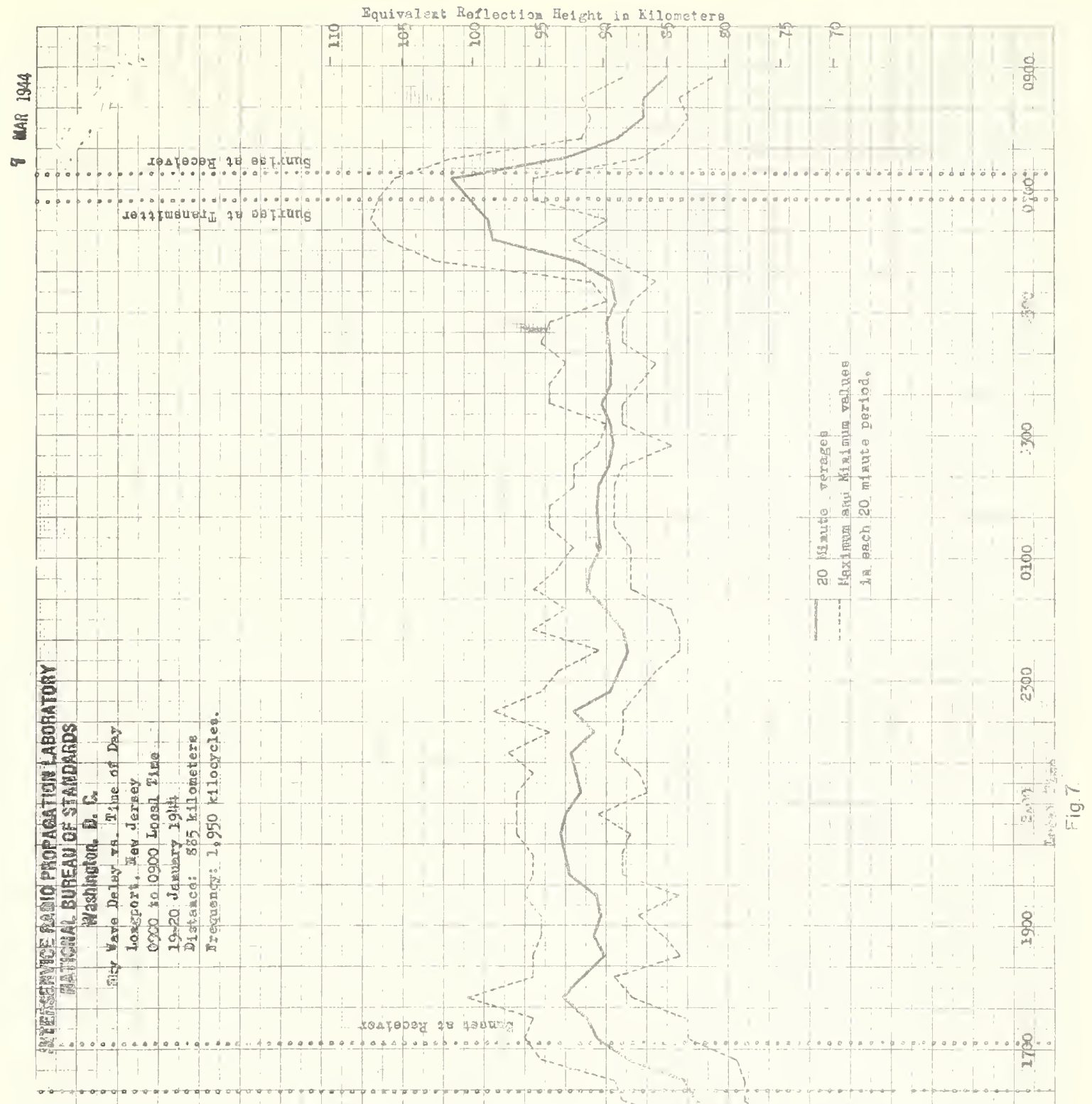

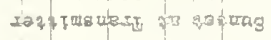

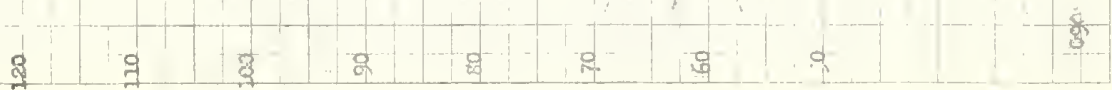




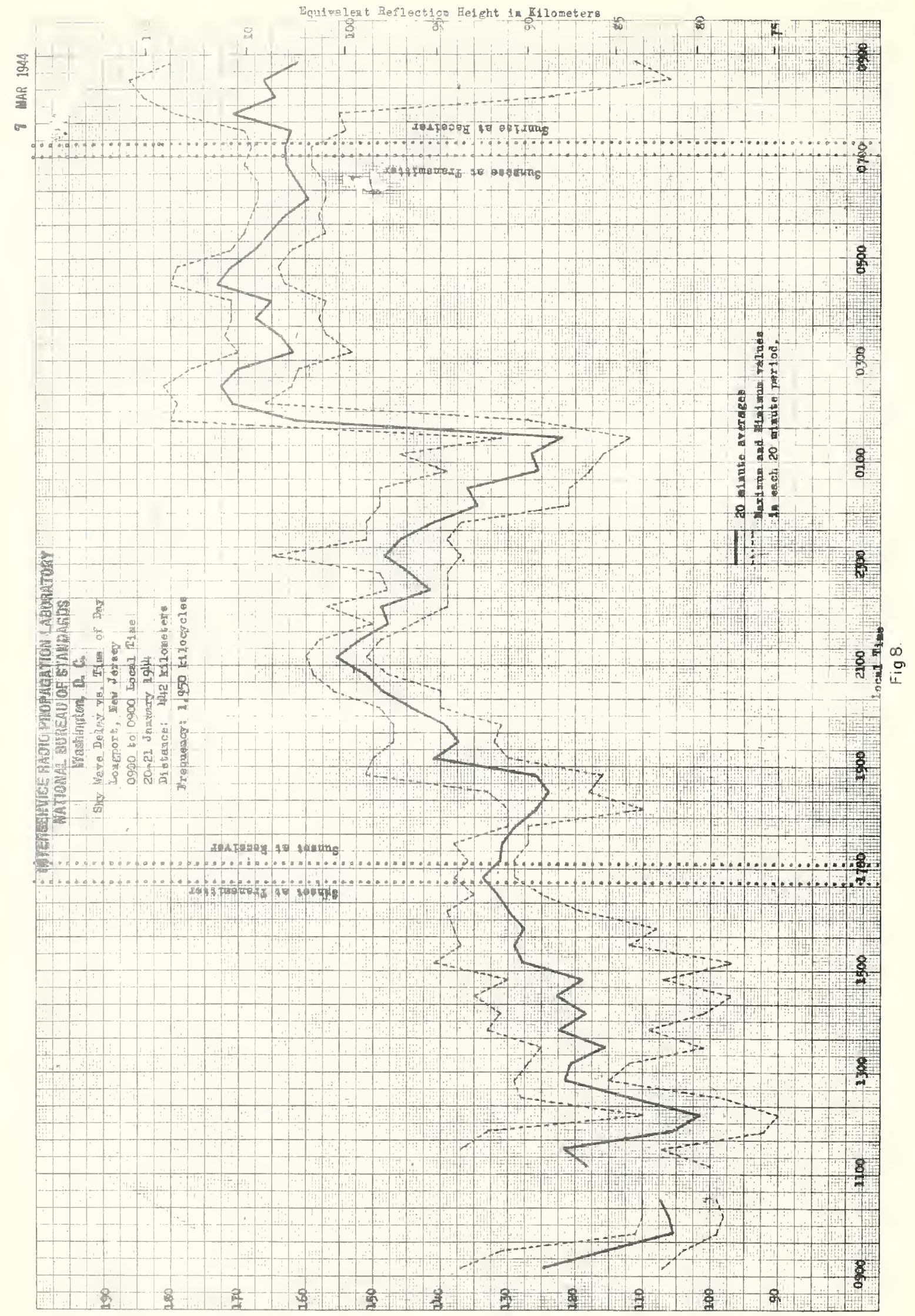




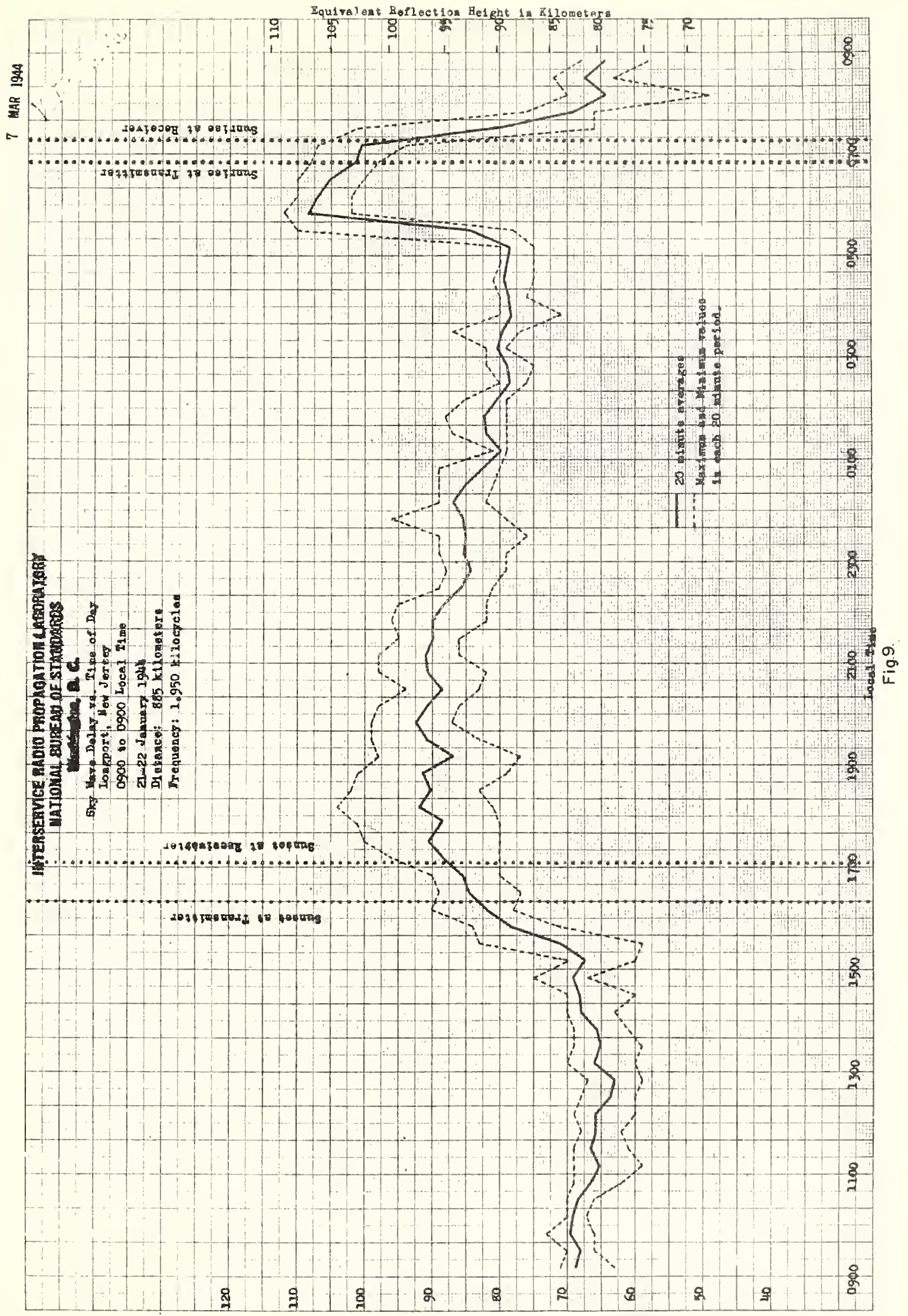




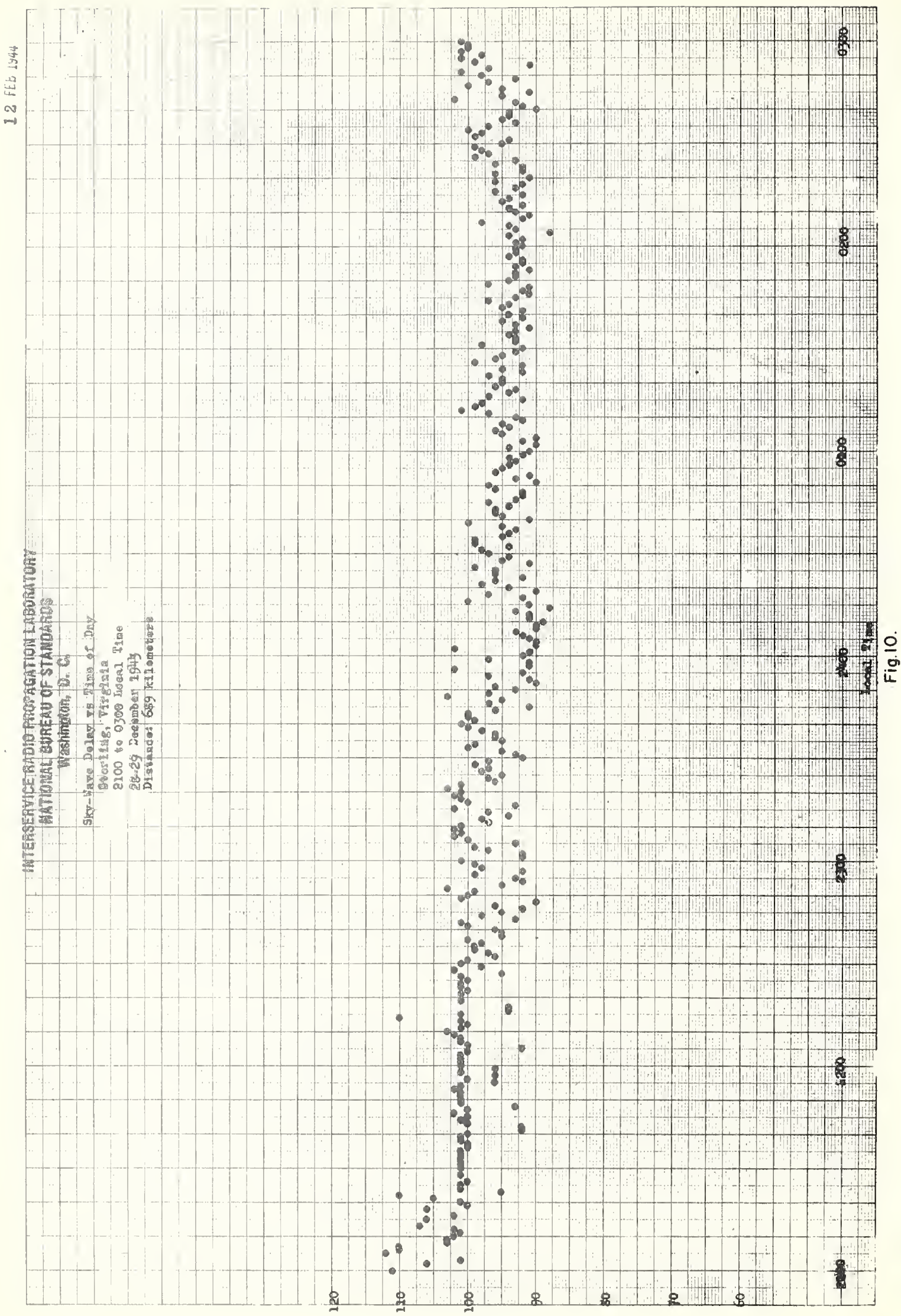




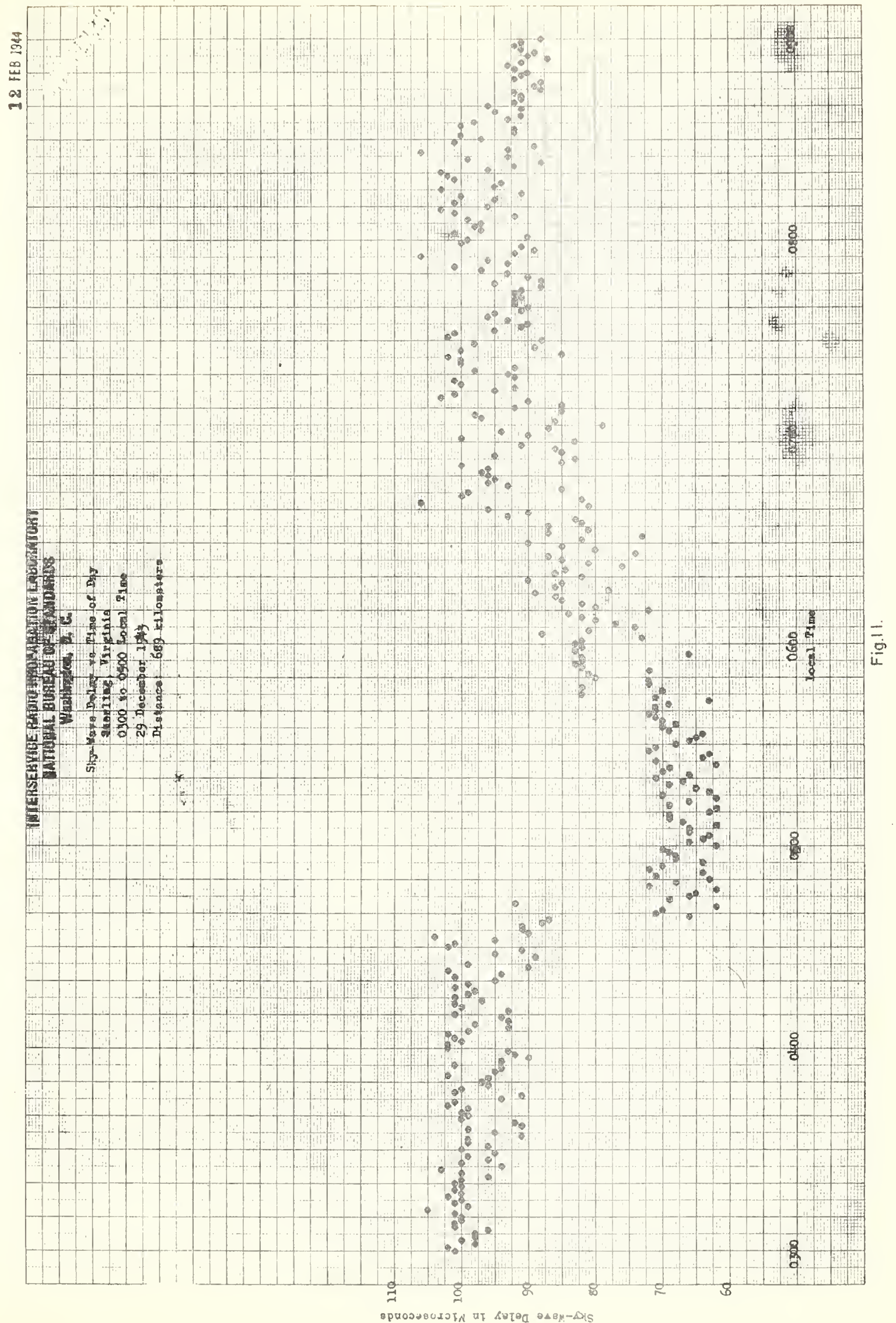




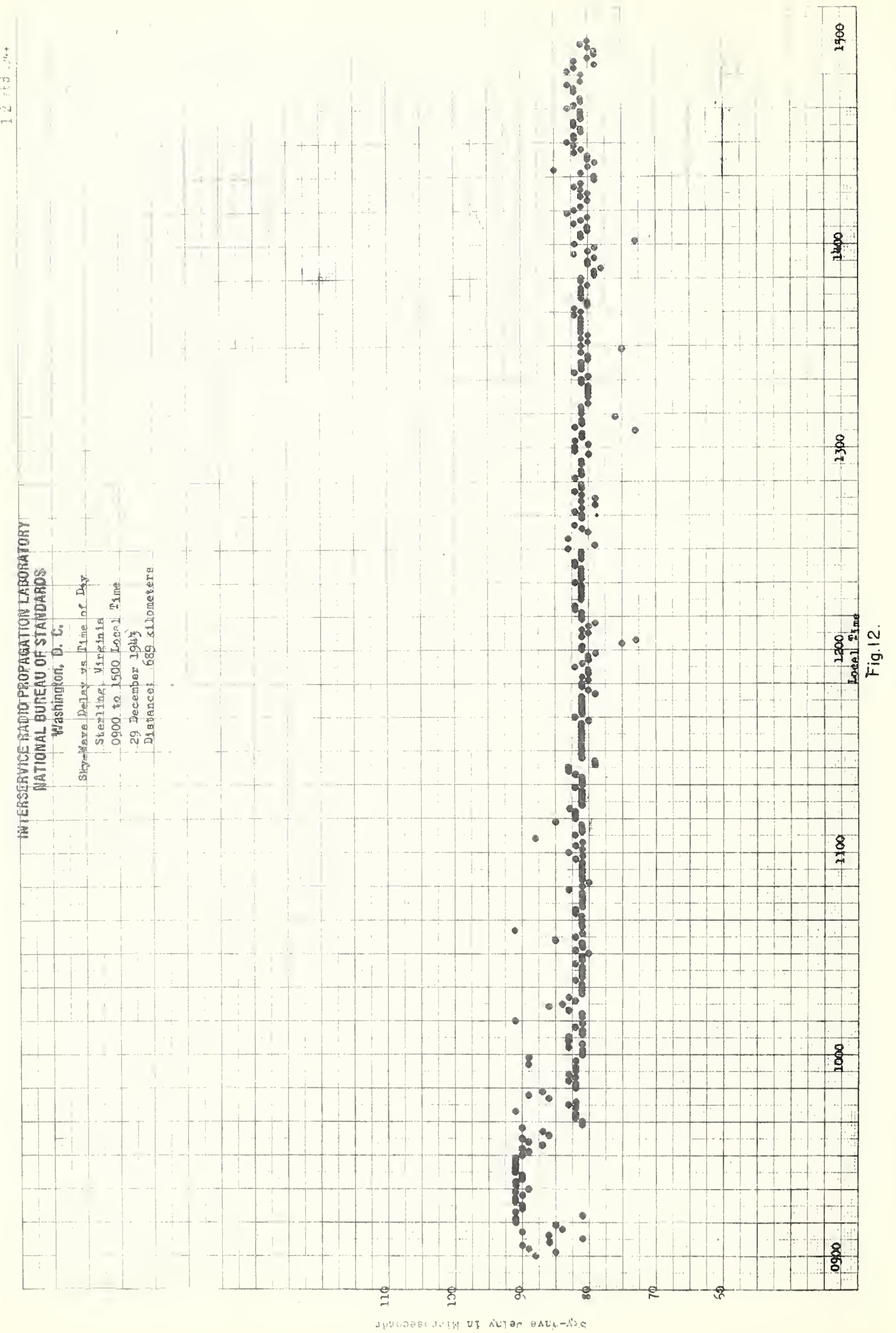




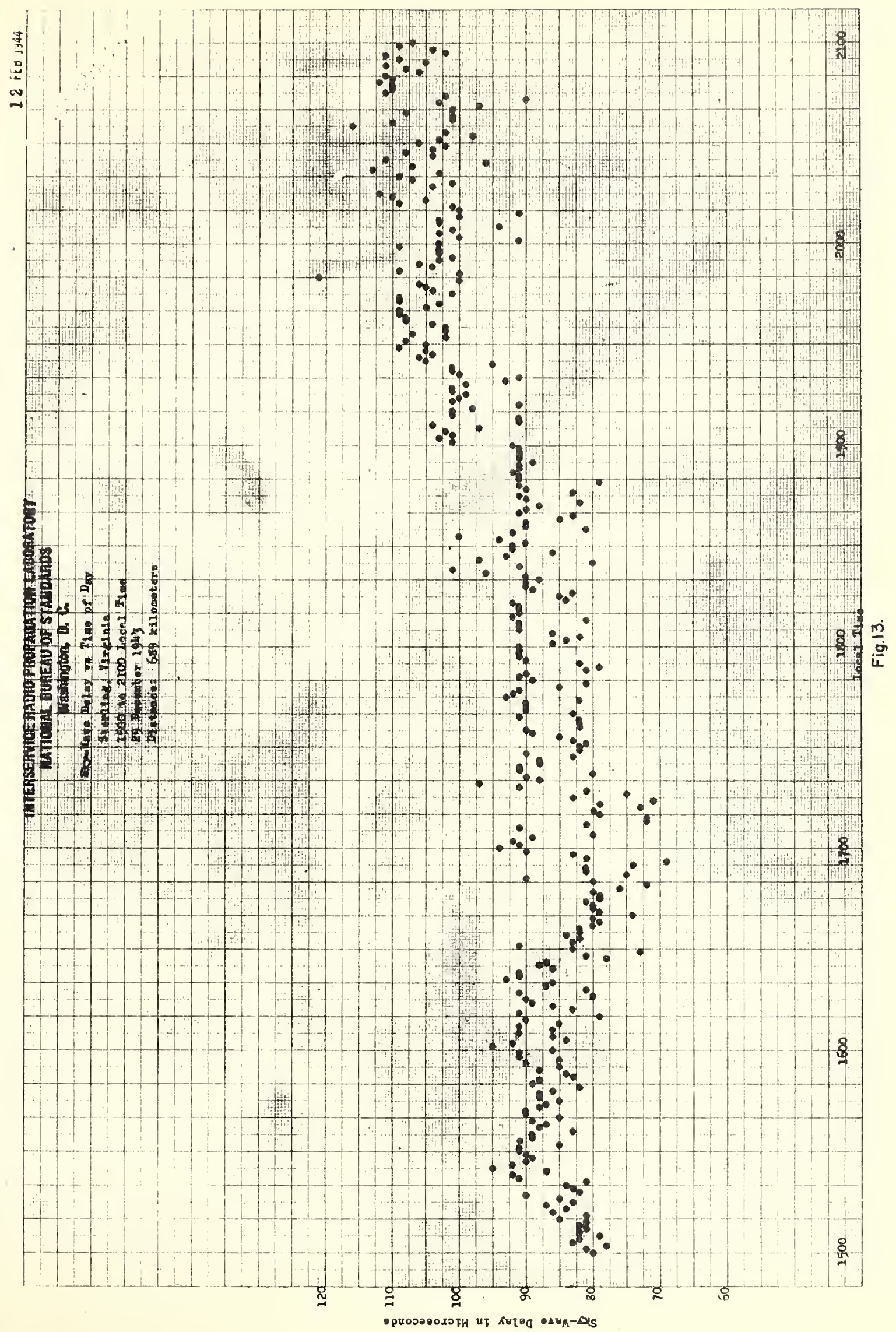



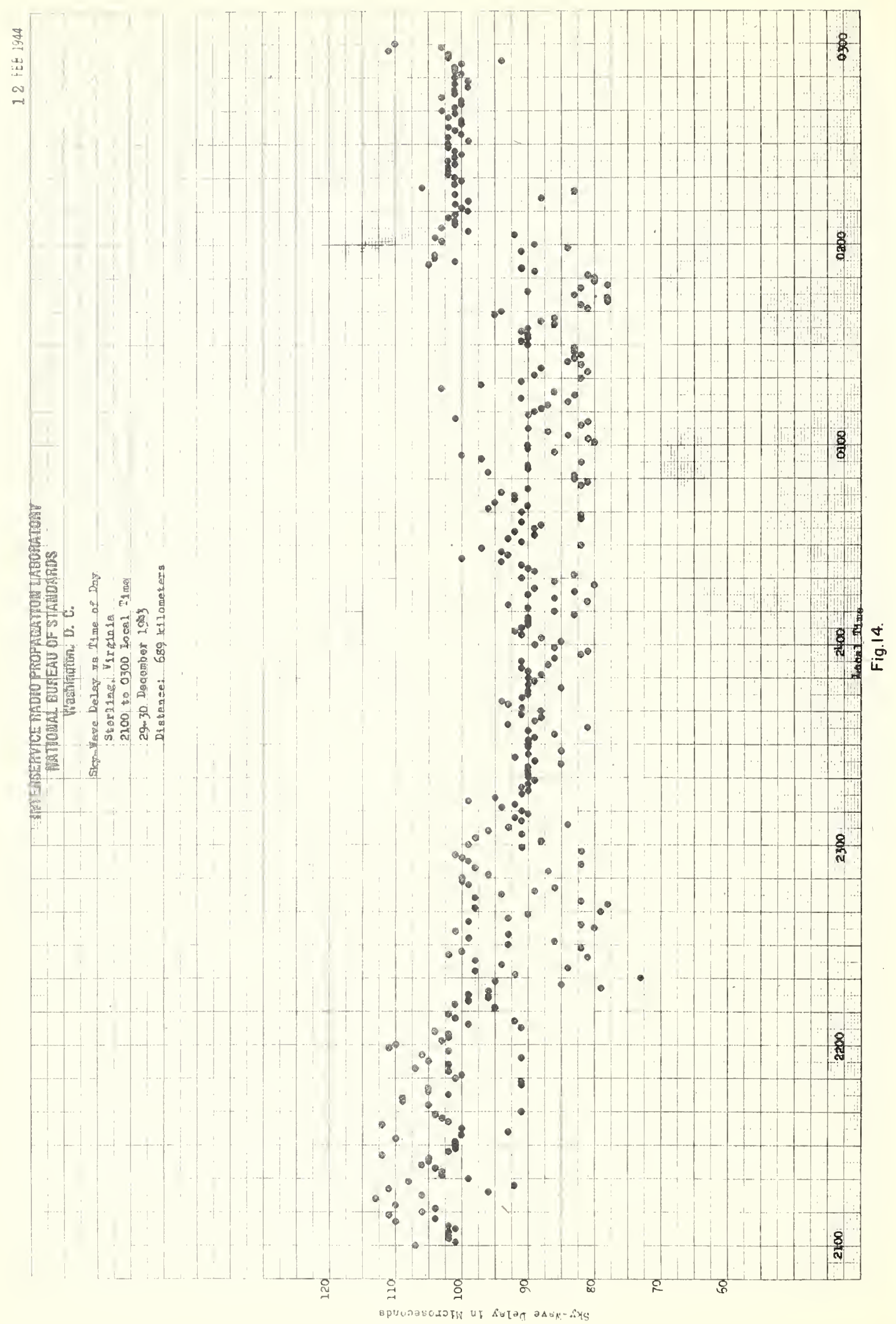


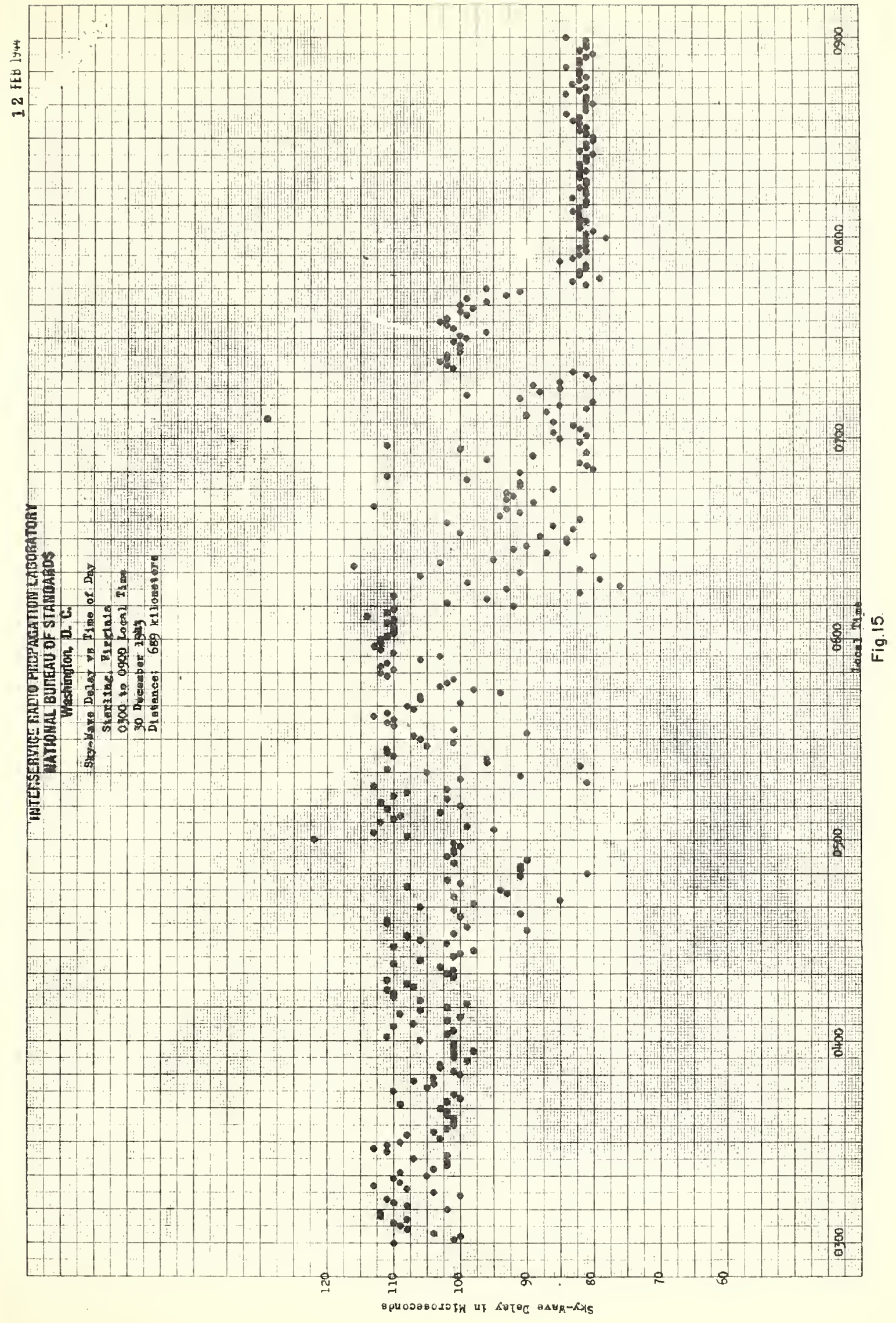




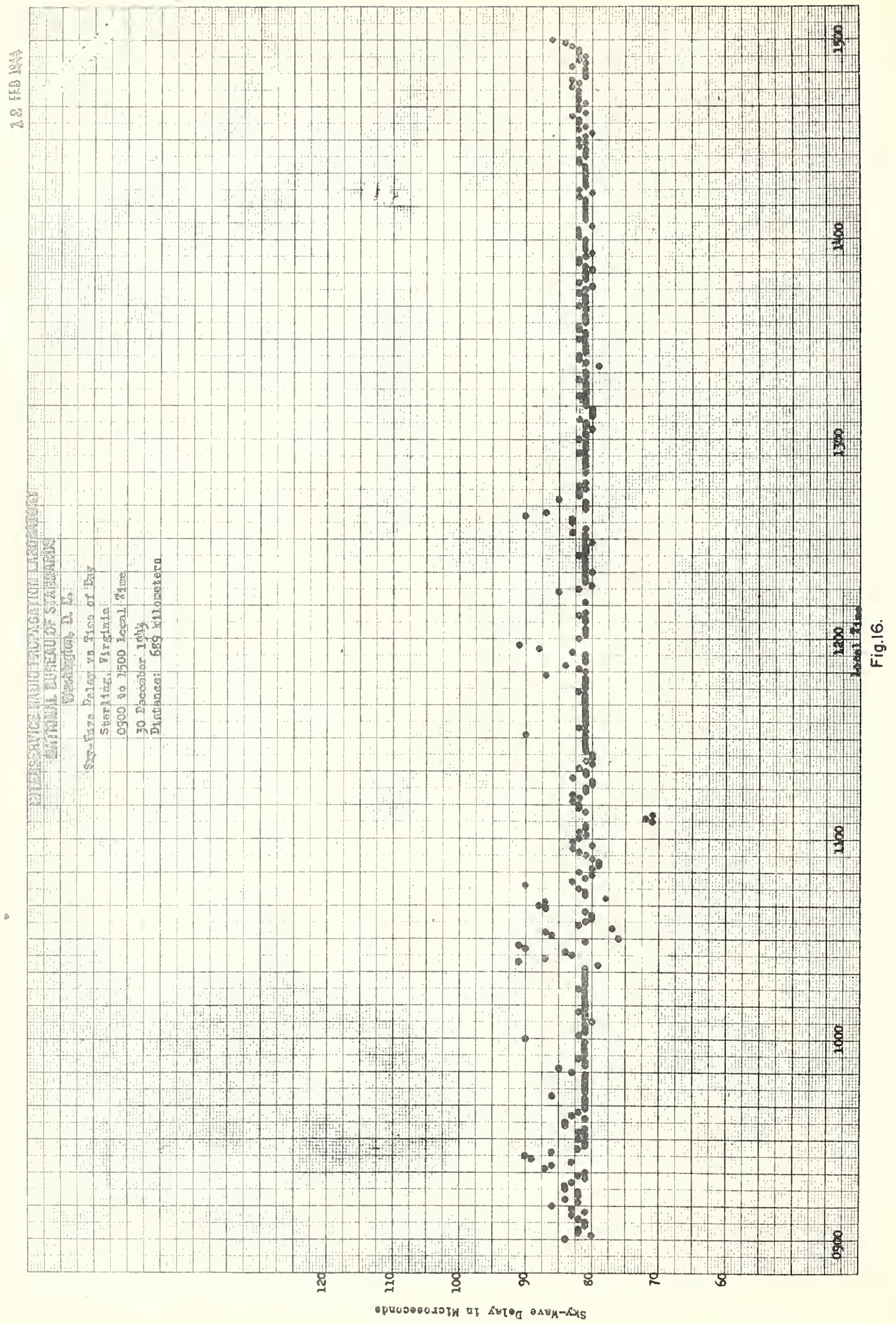



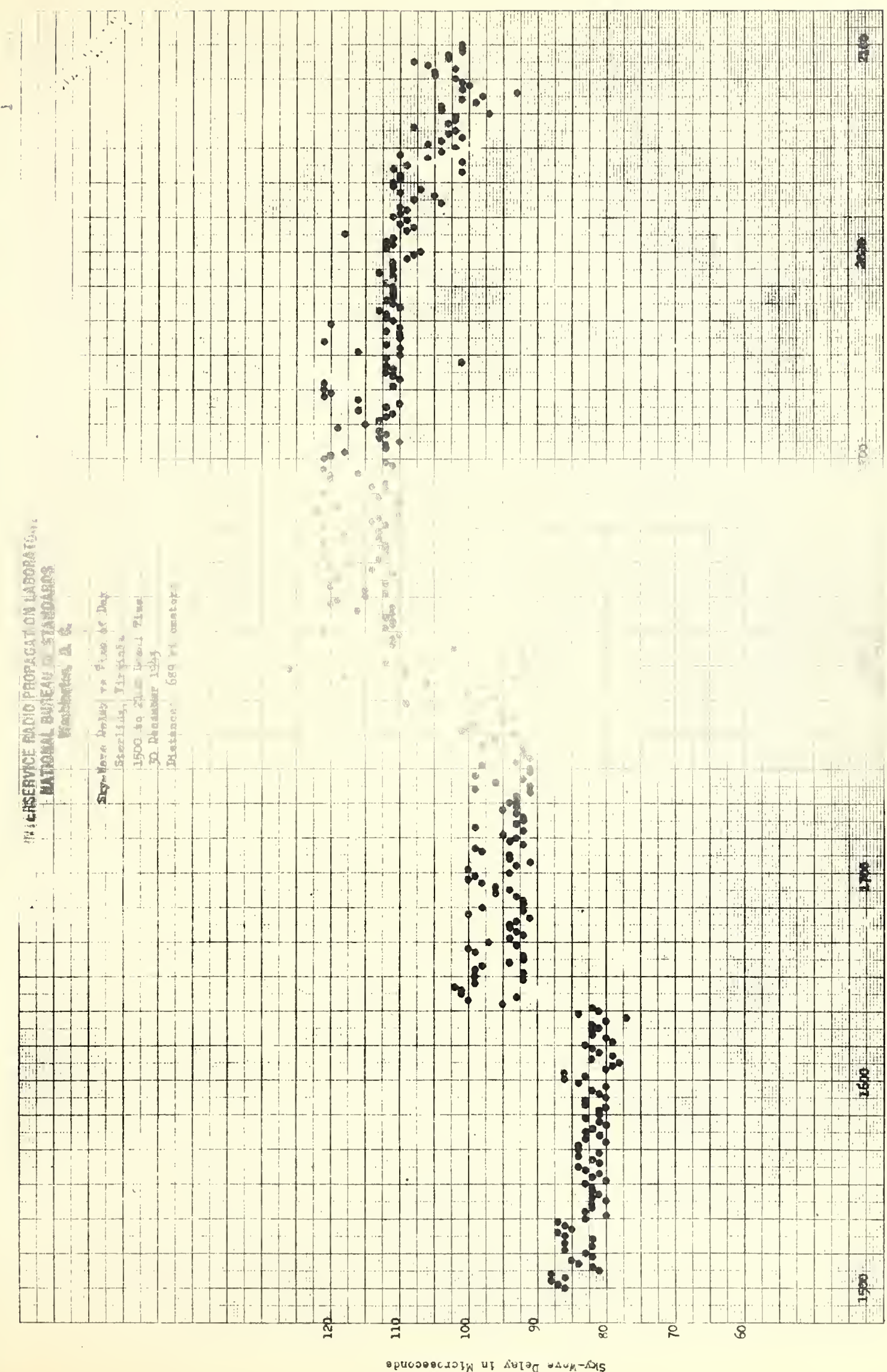

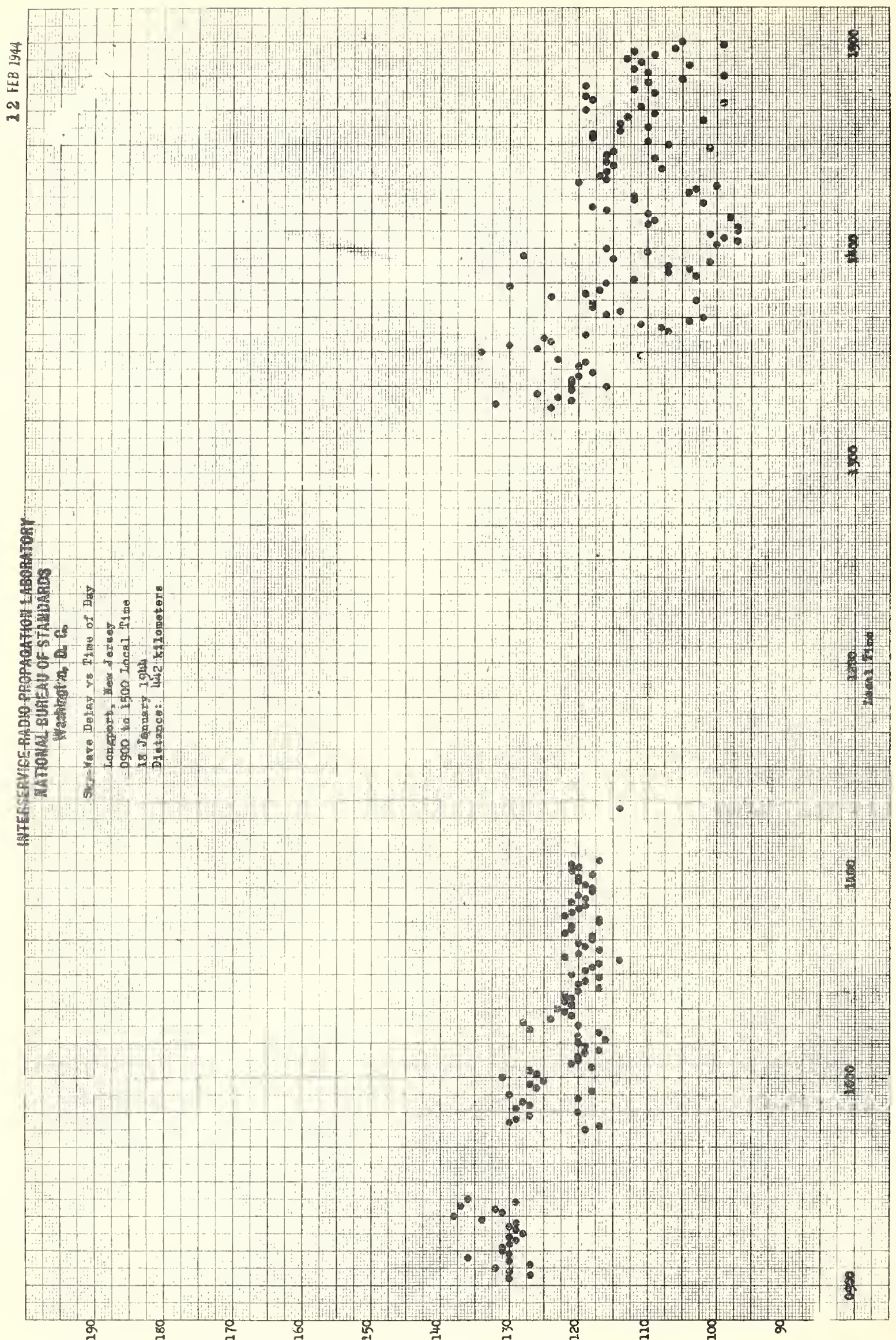


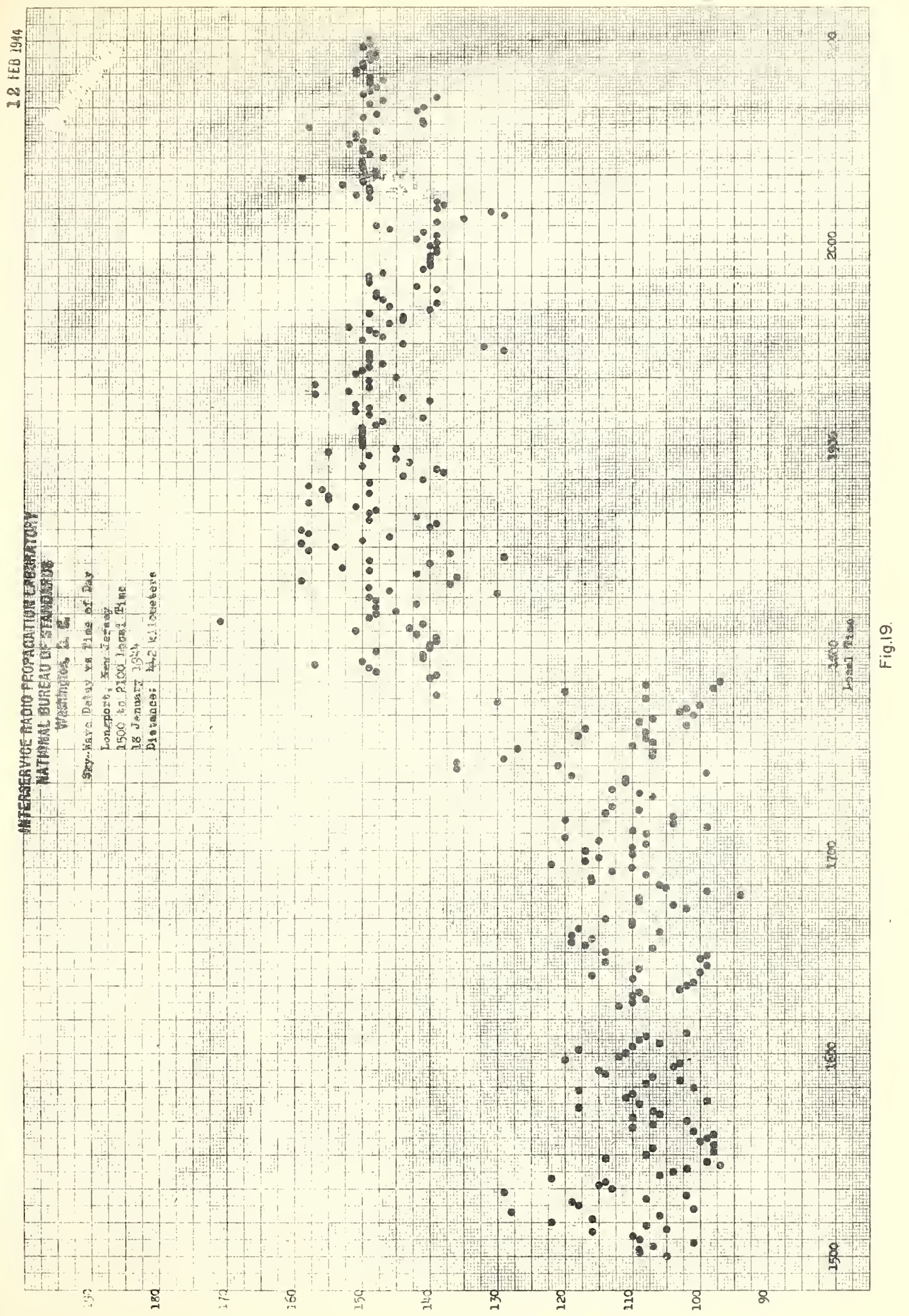



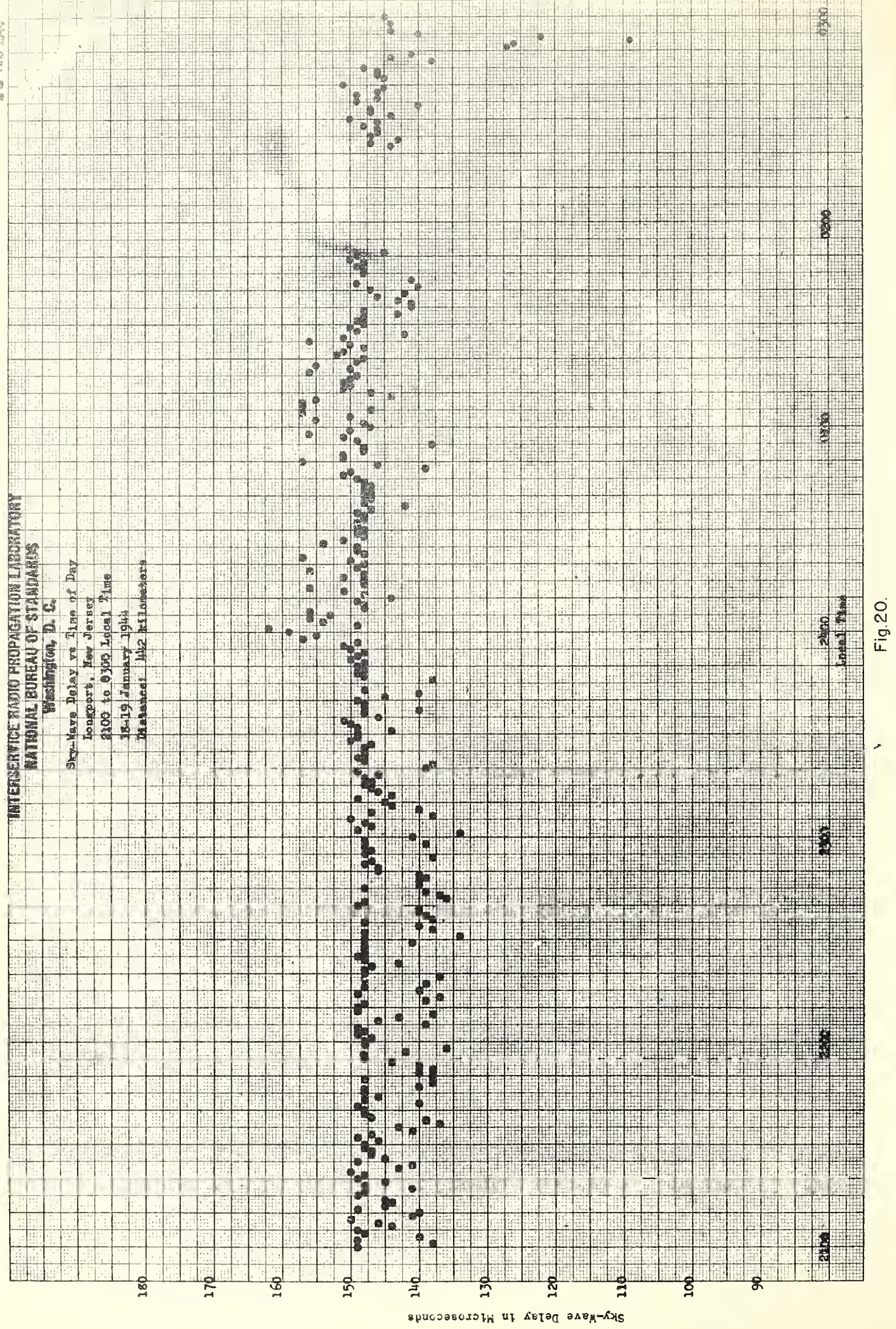






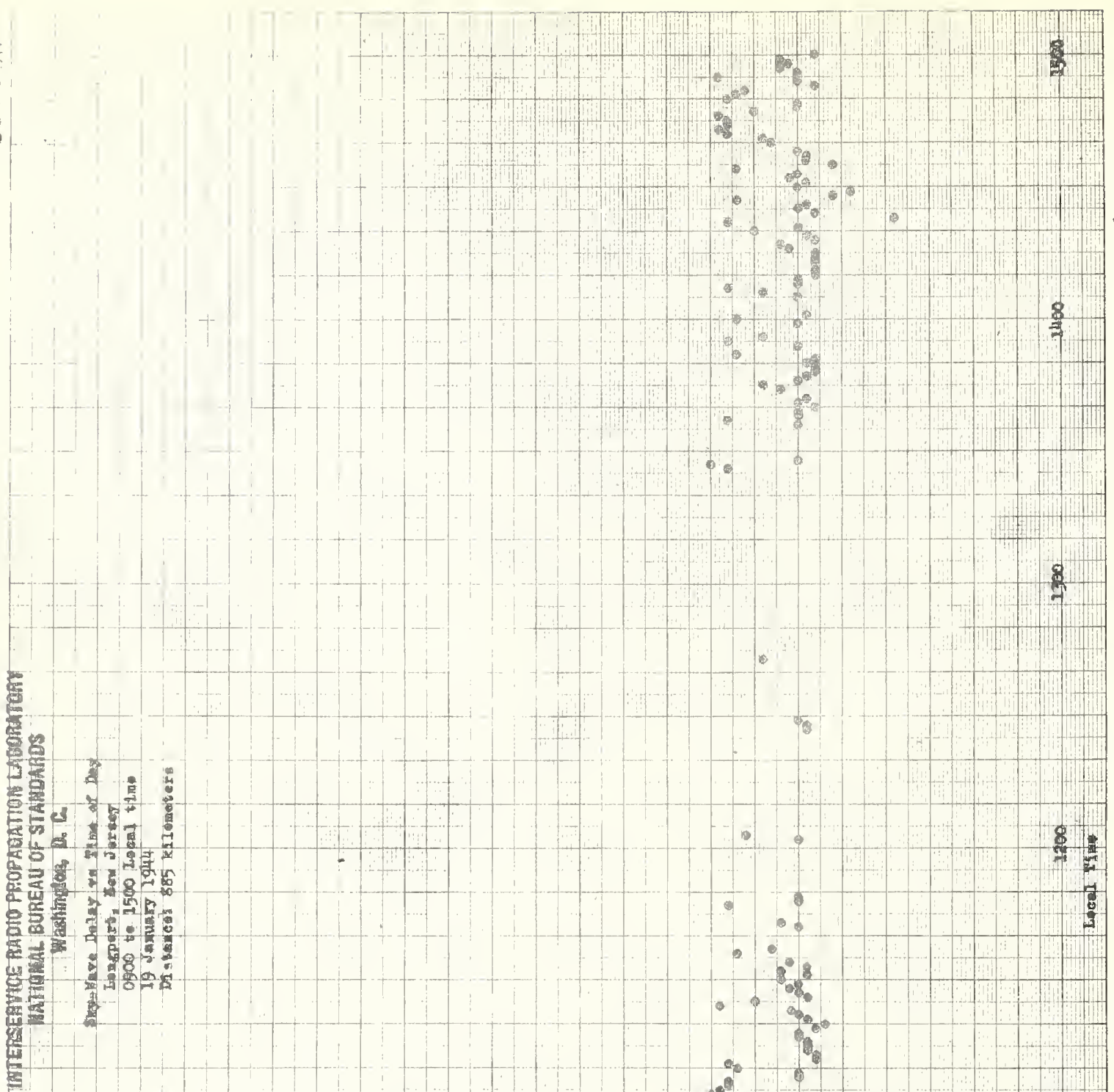


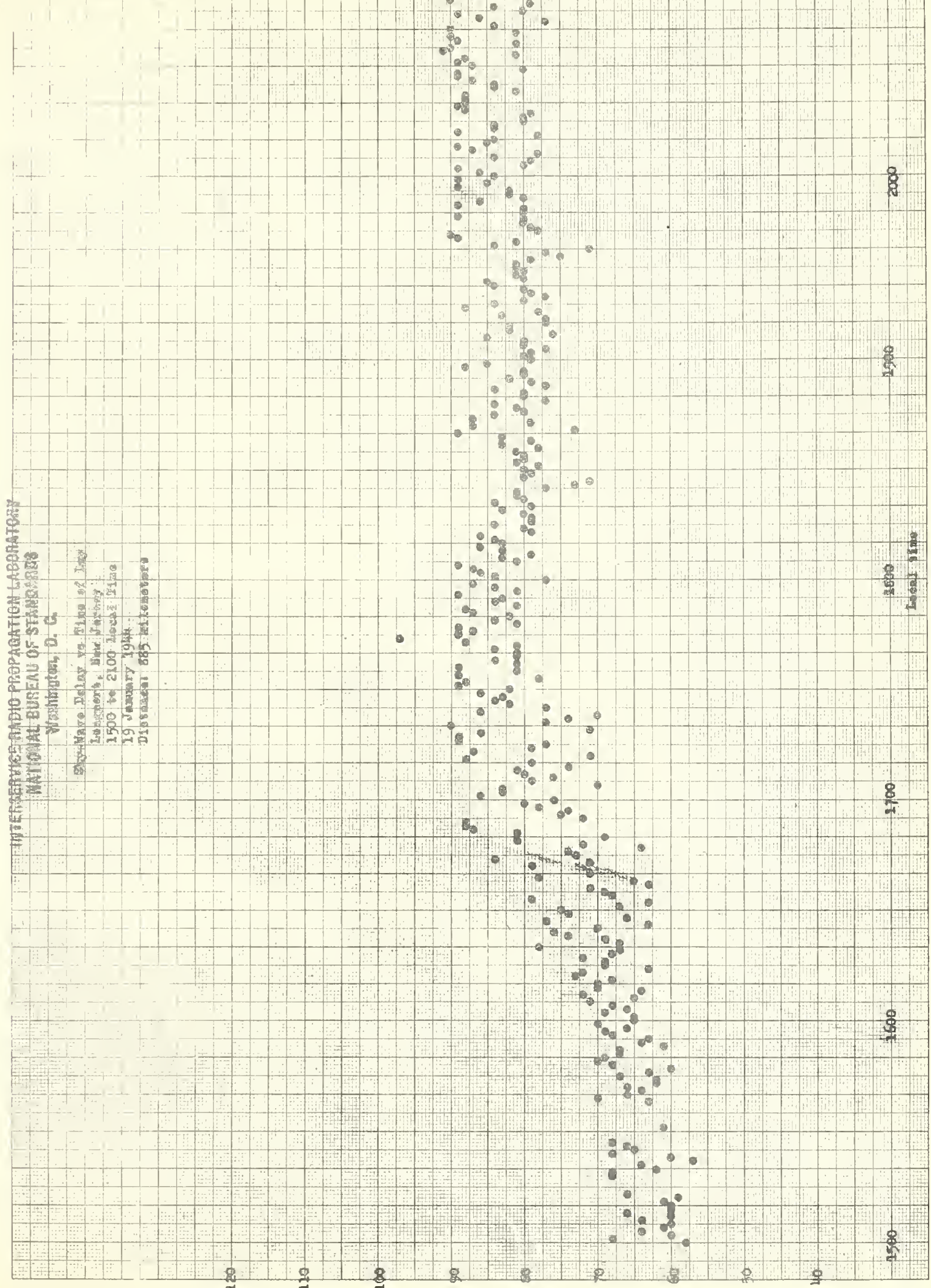




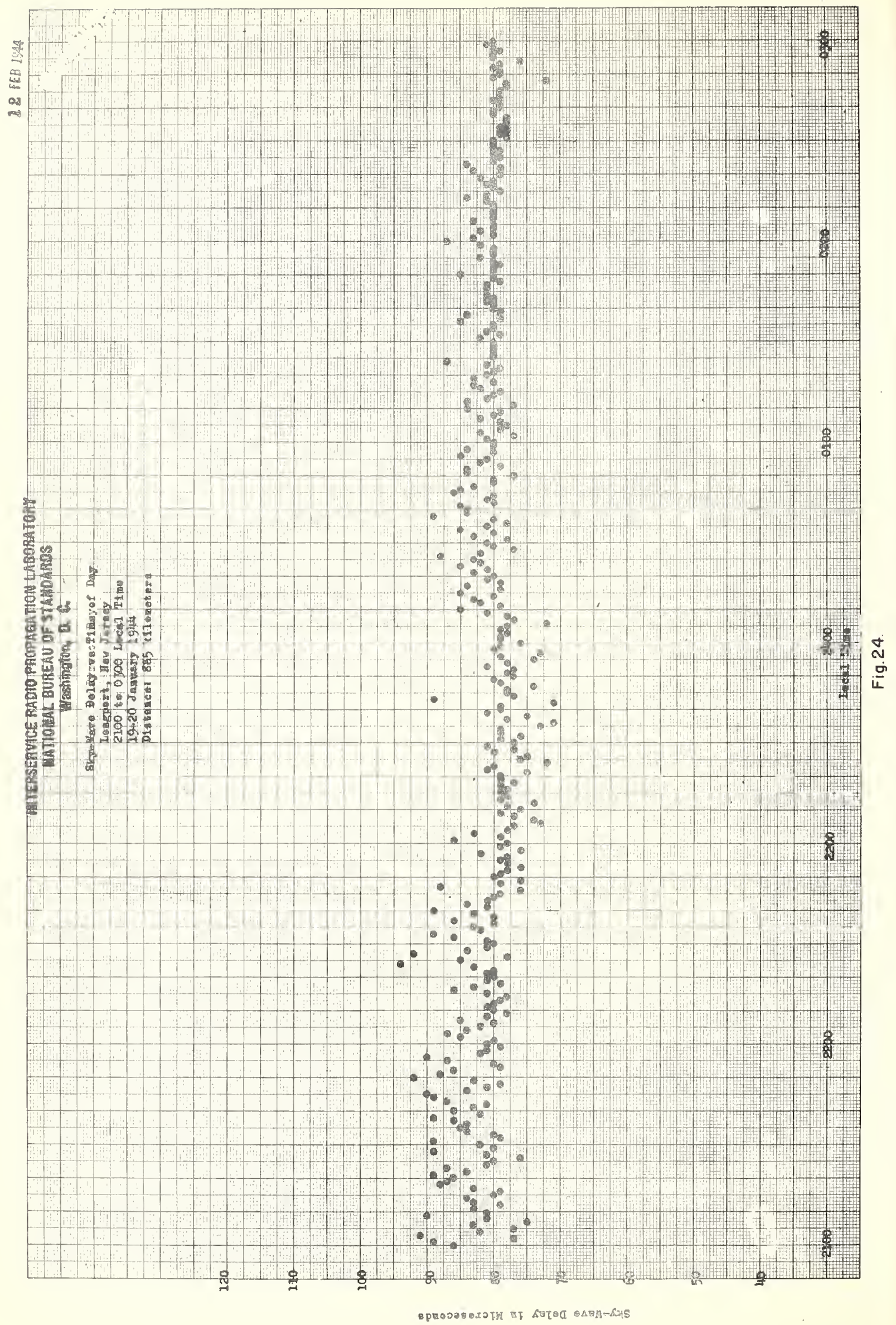


琶
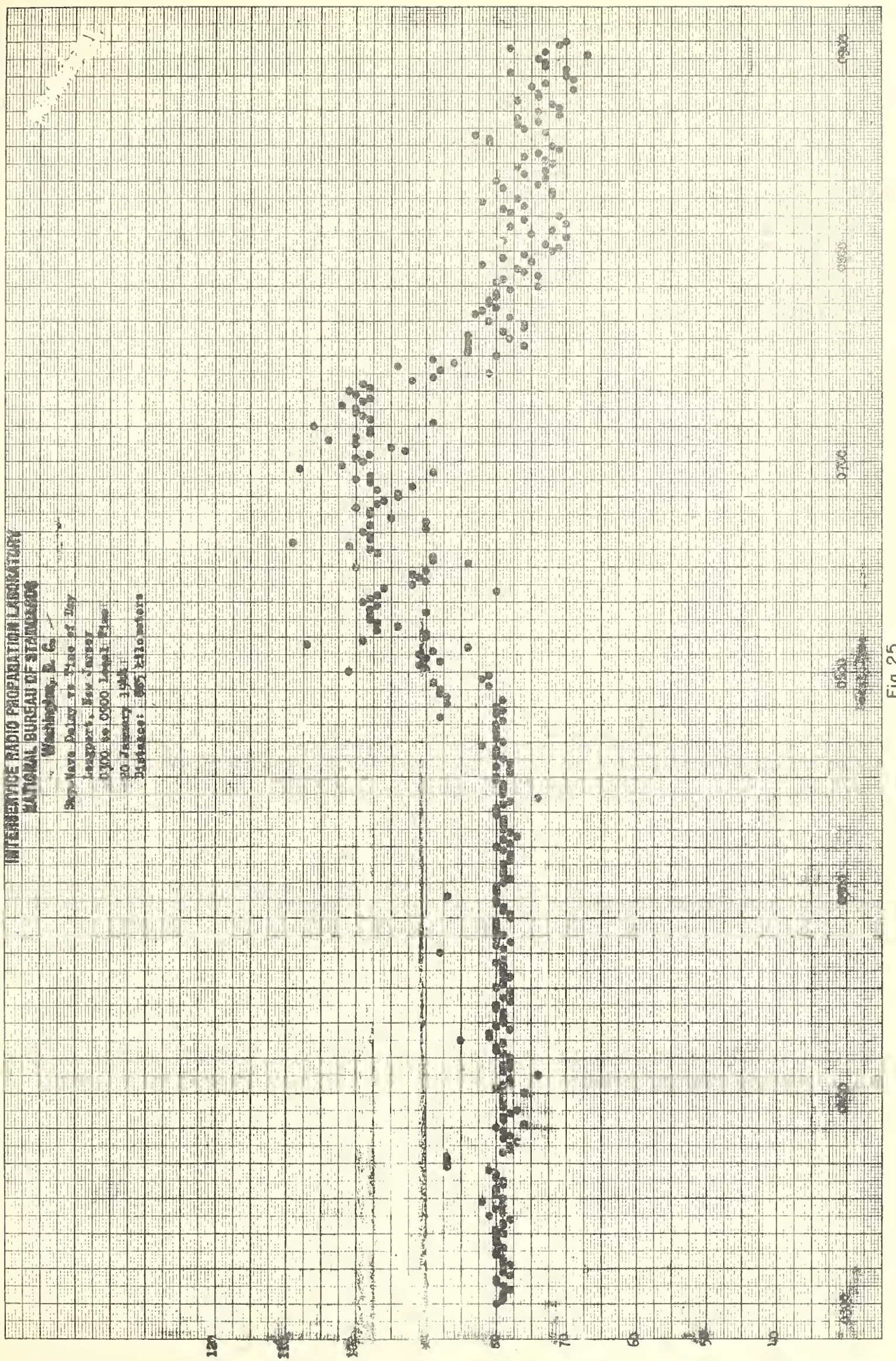

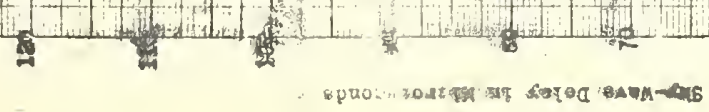



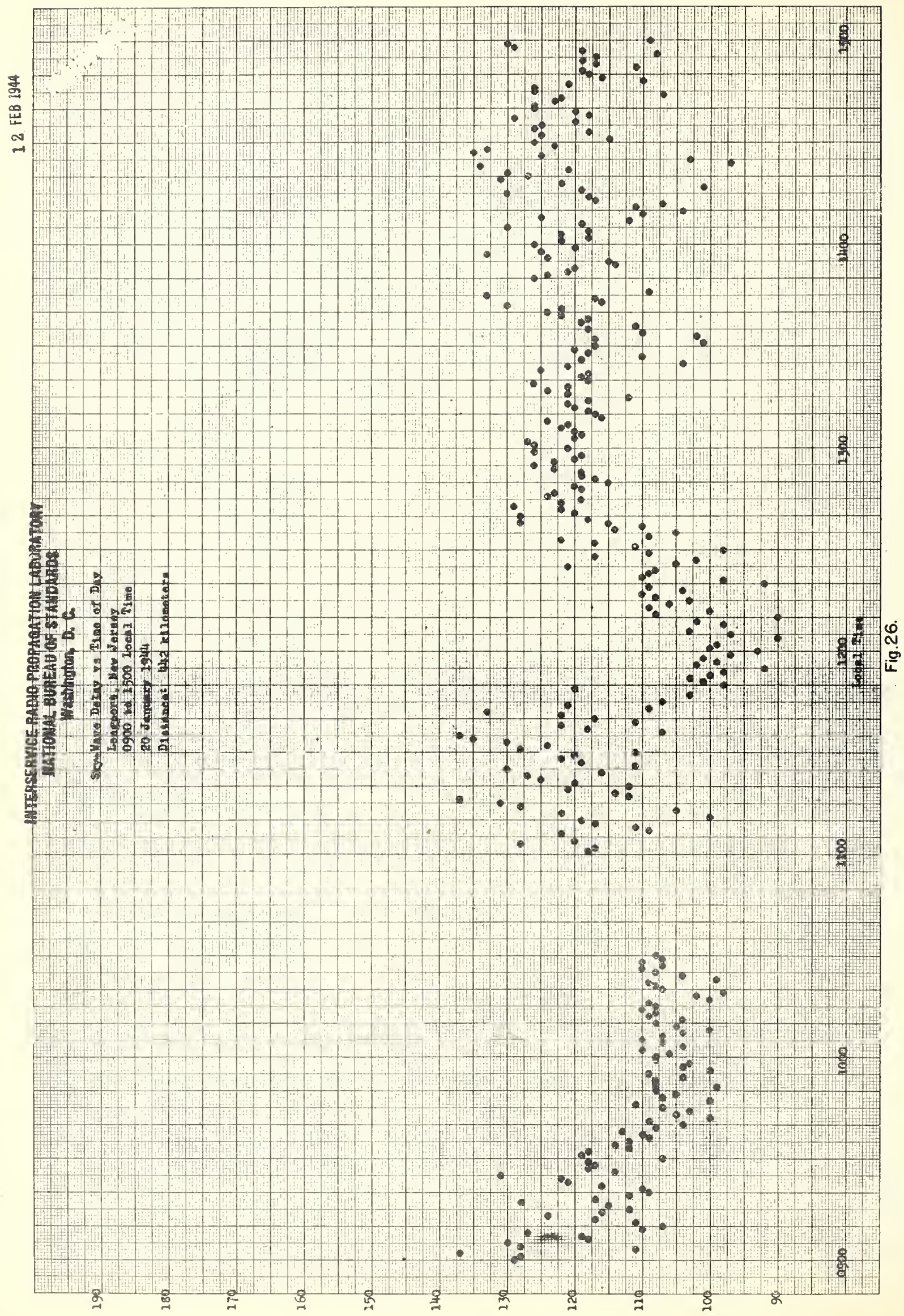


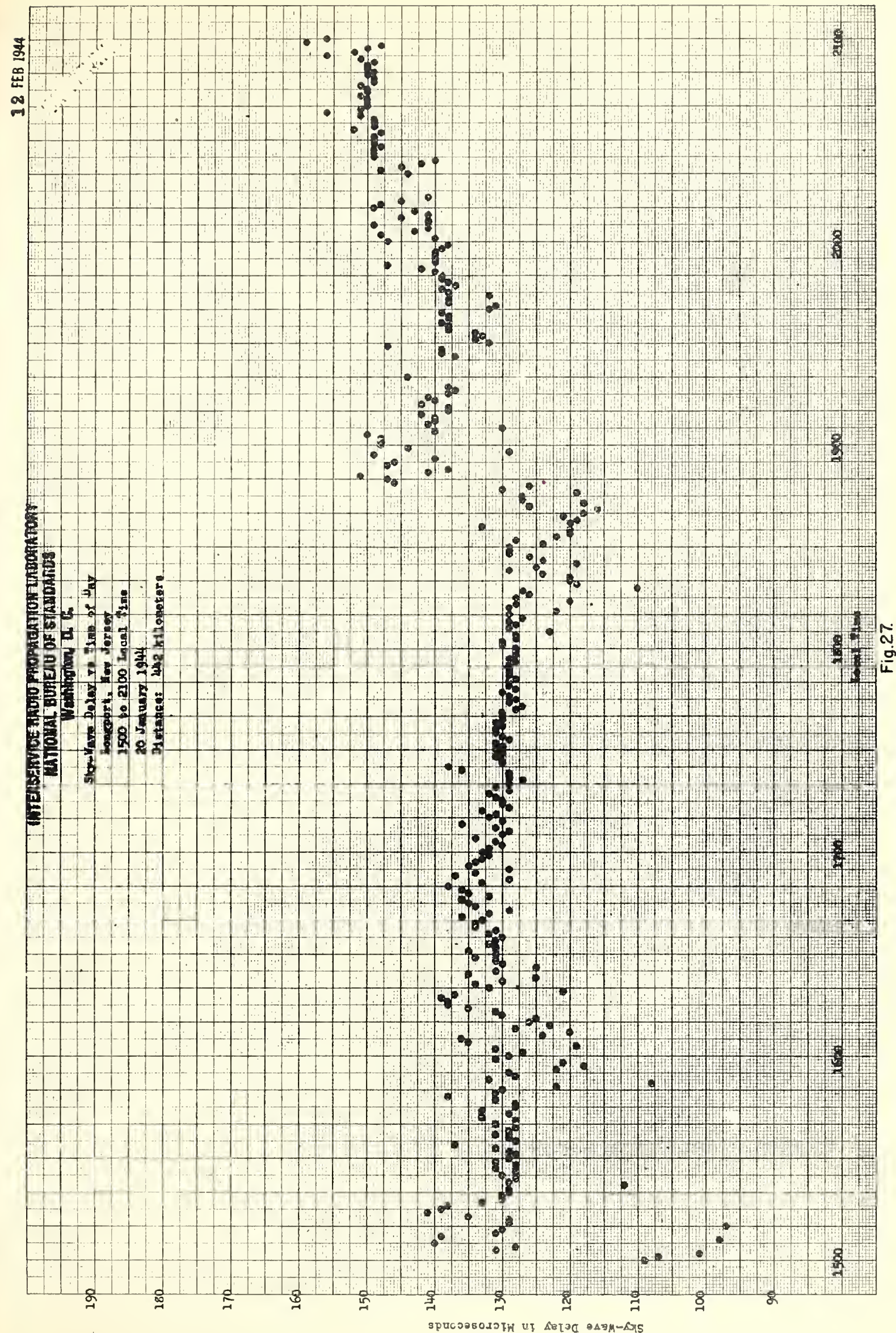




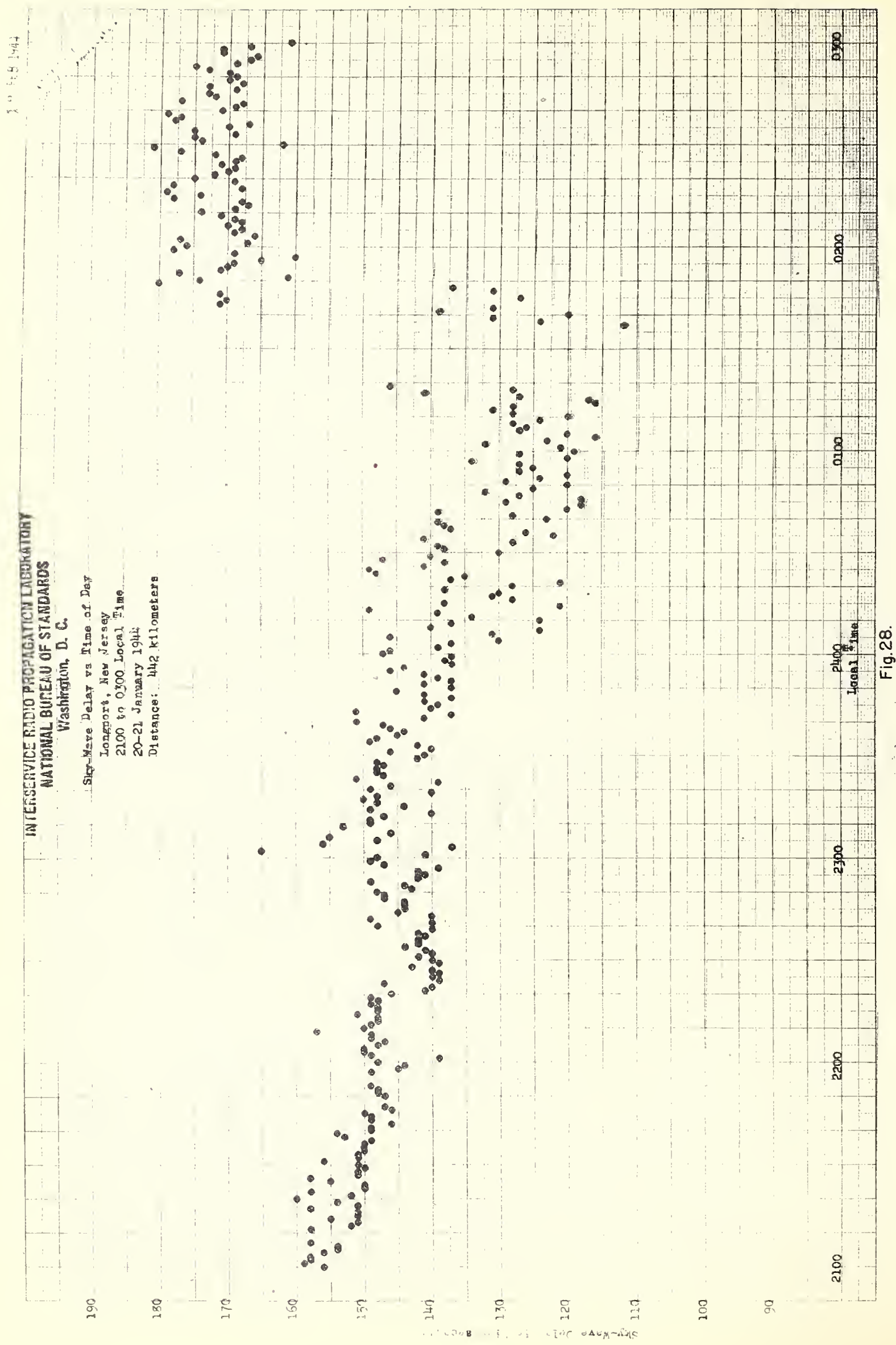




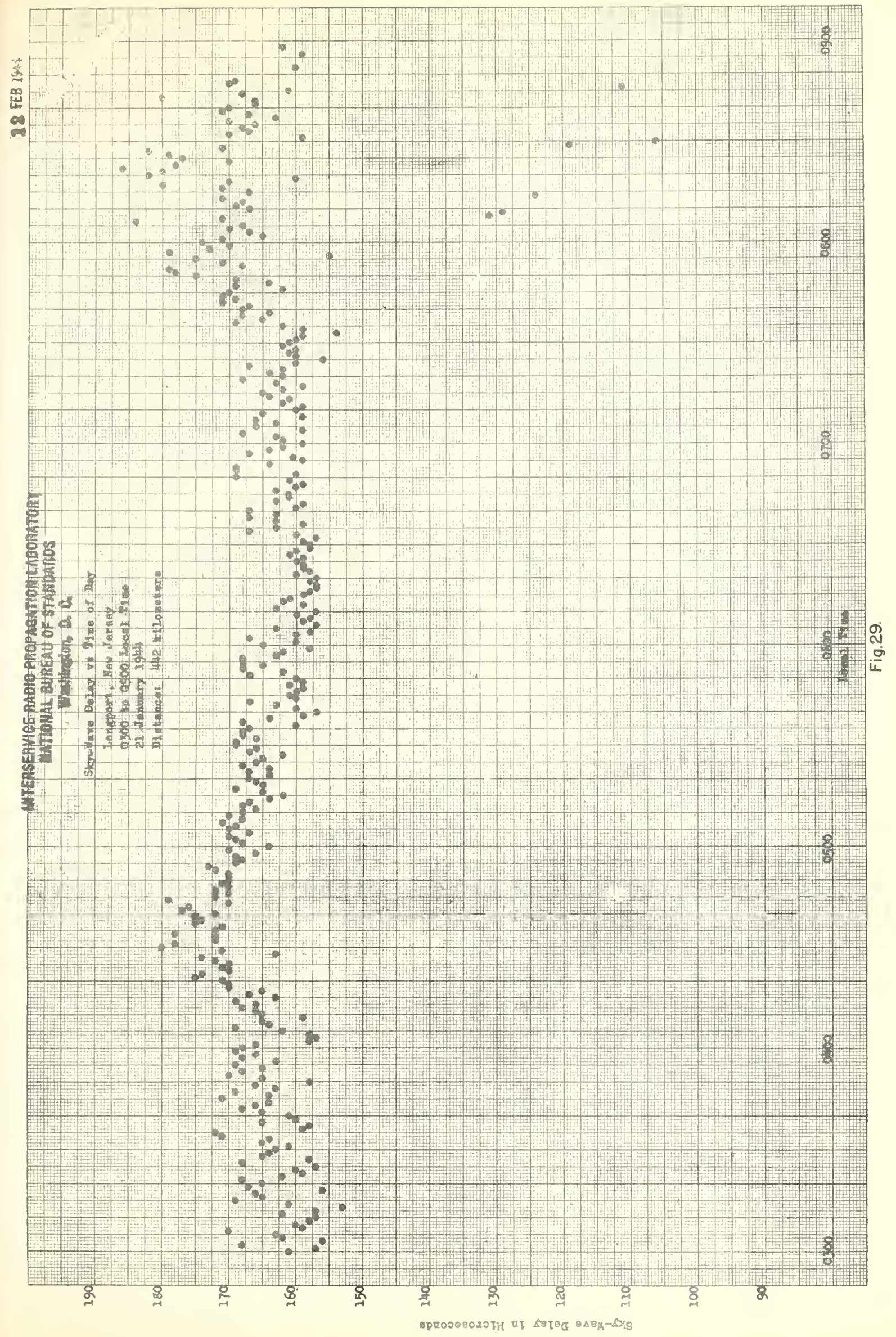




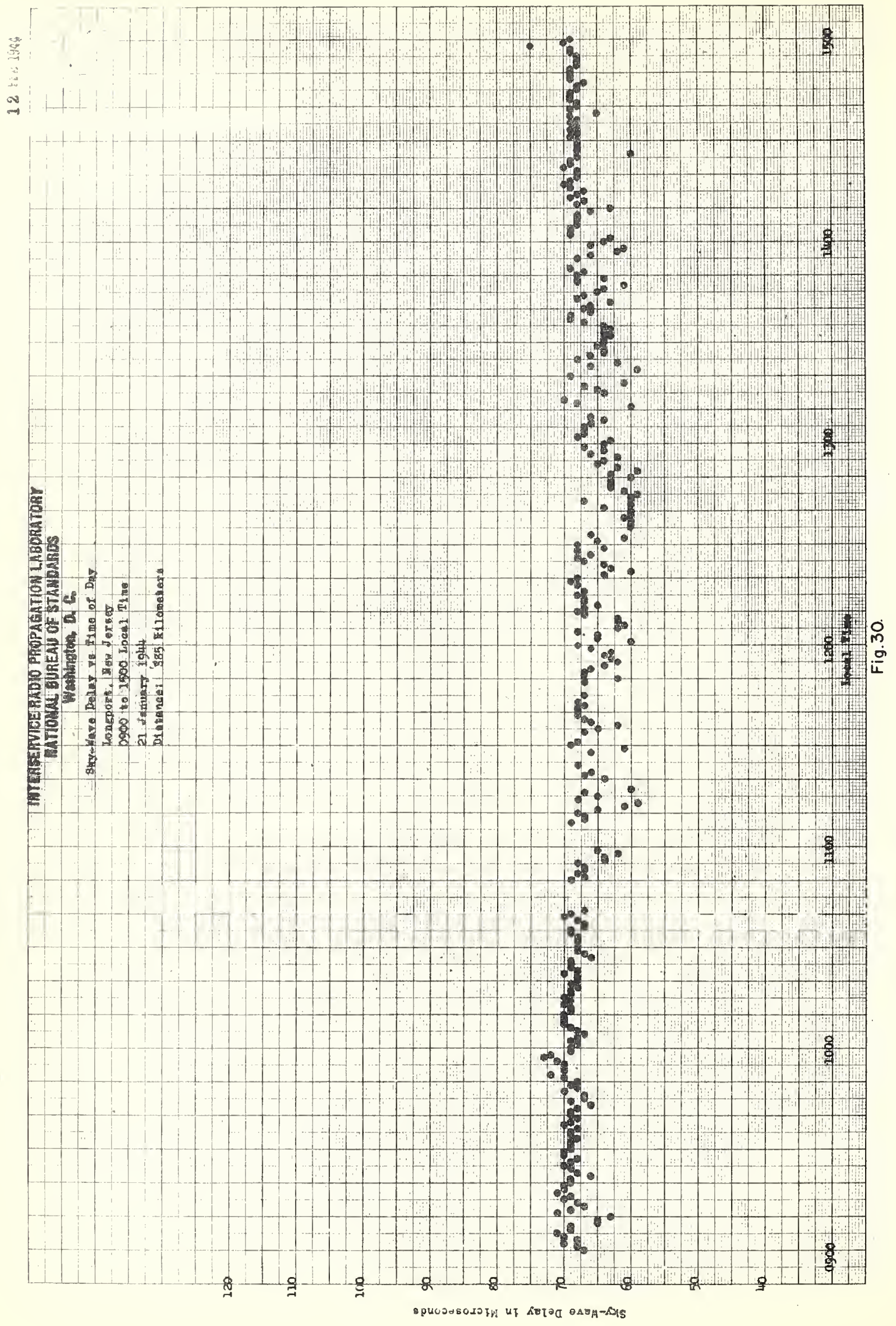



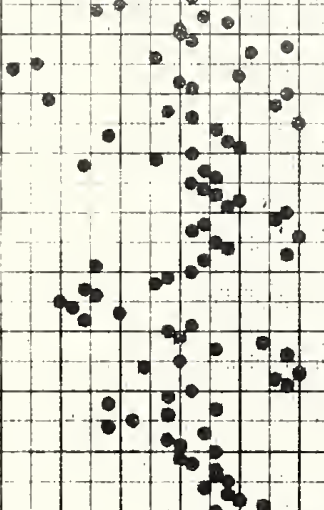

$1+9$

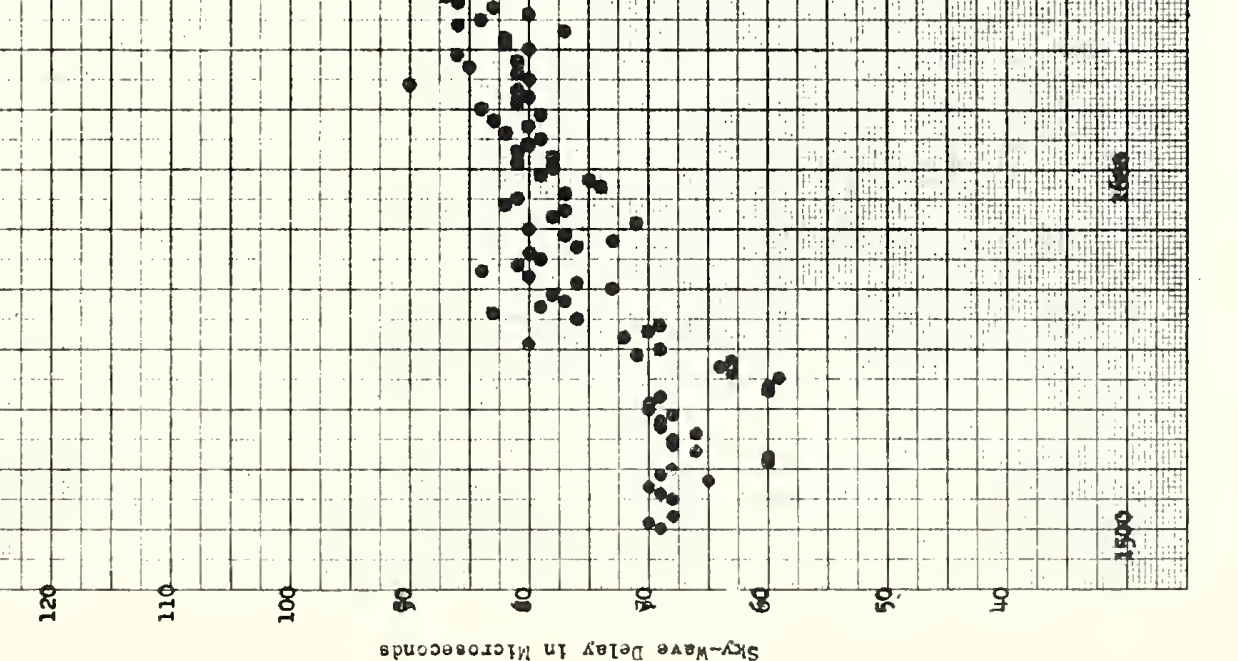




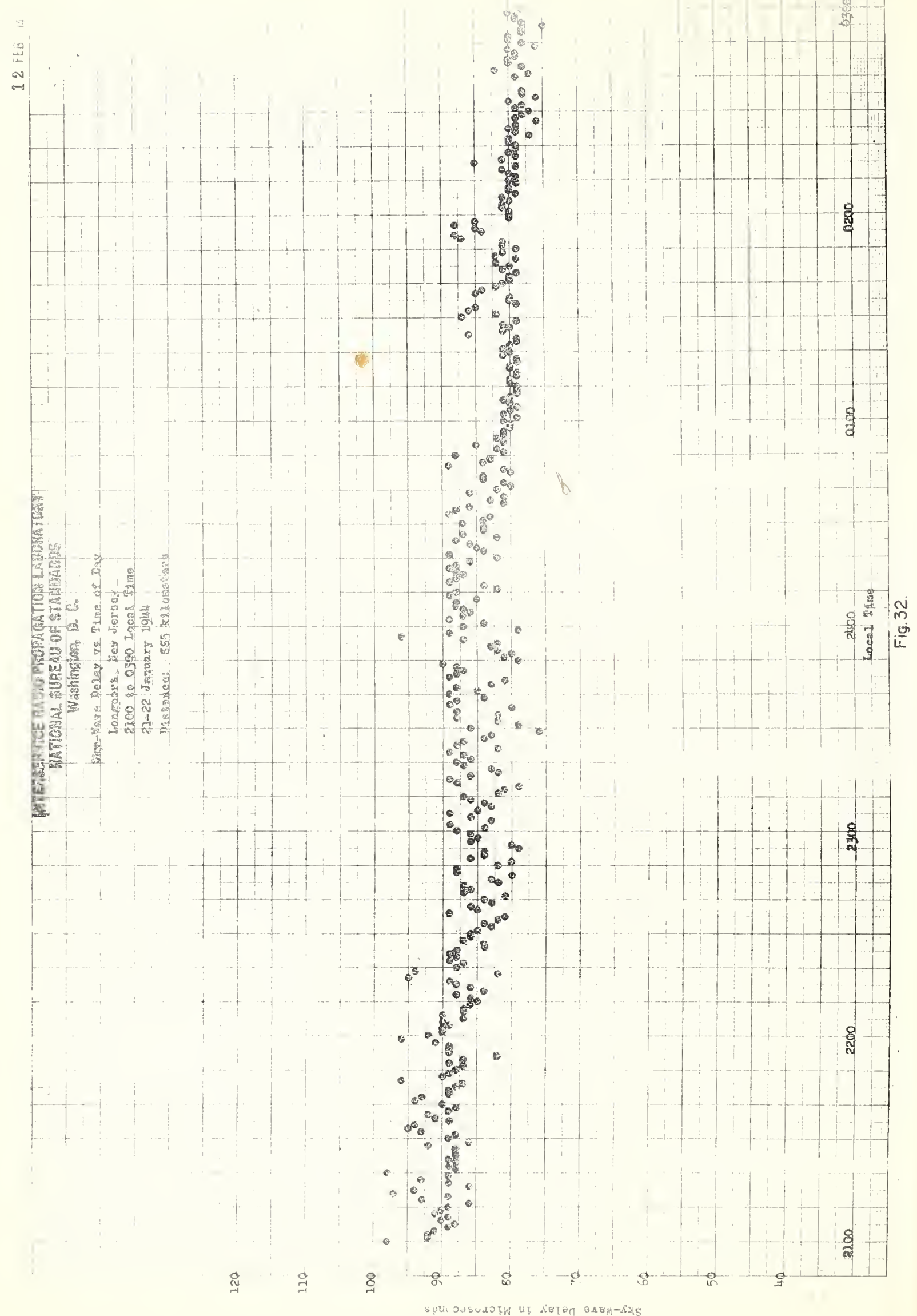




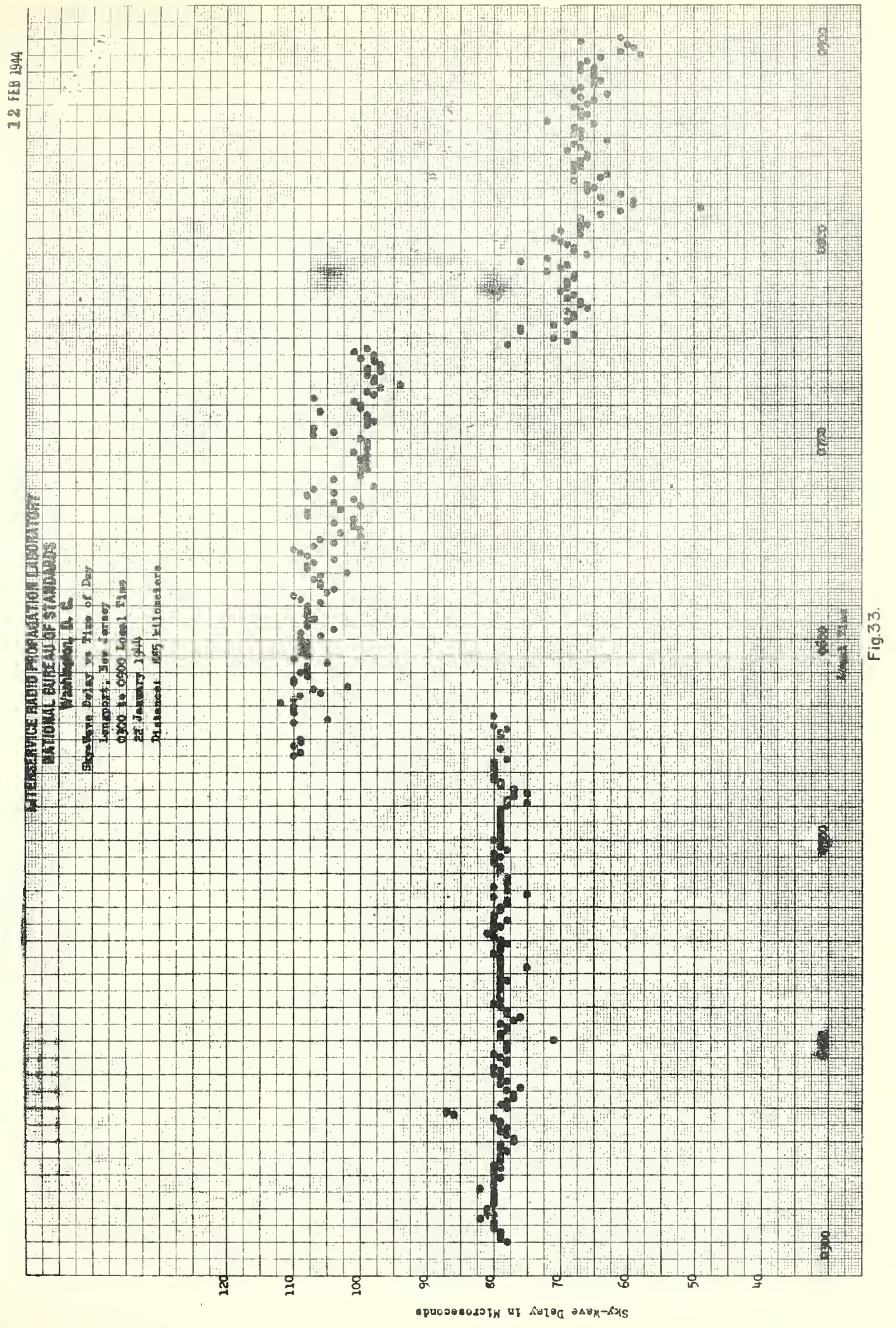



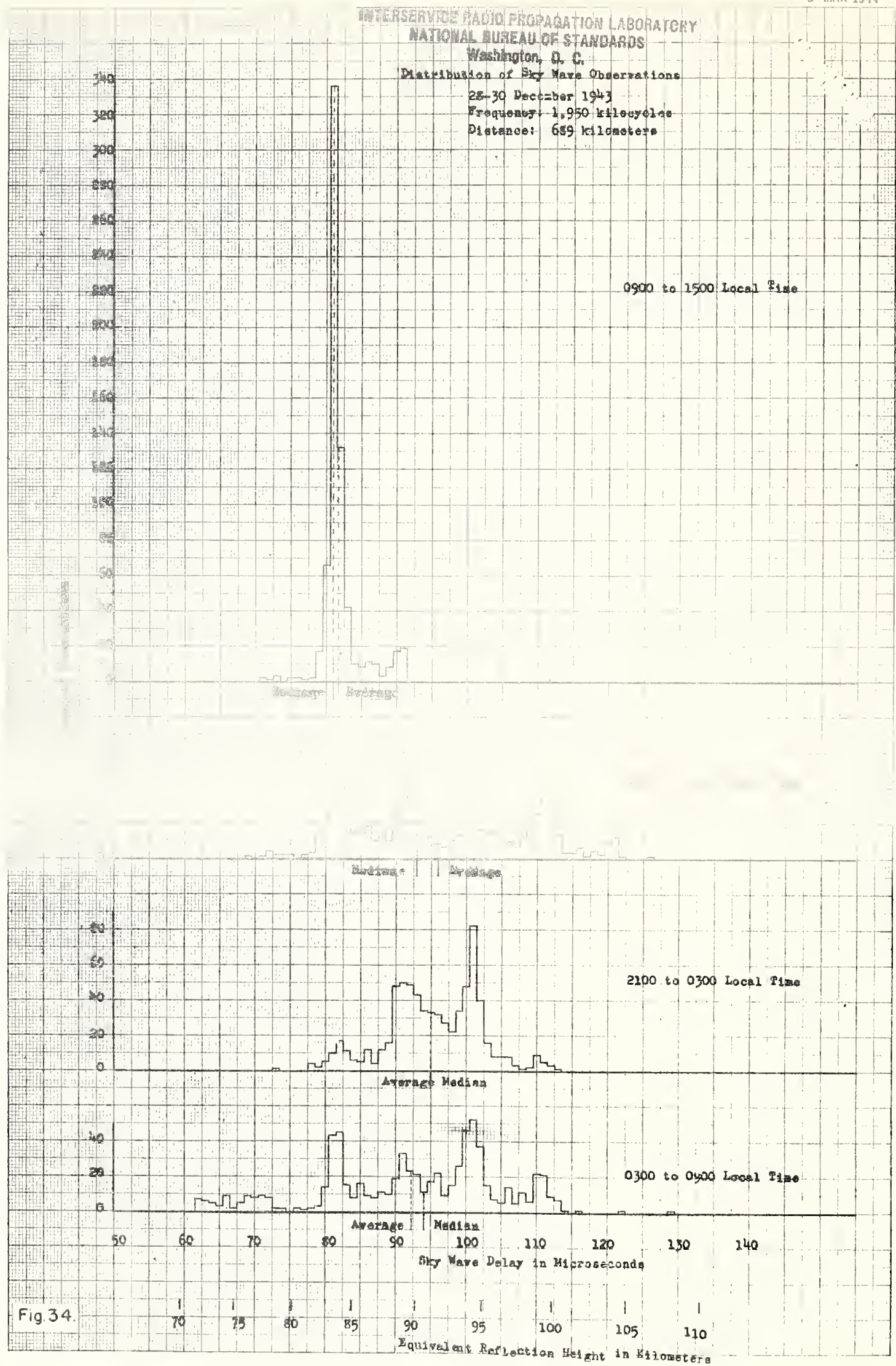
INTERSERVICE RADIO PROPAGATION LABCRTCOTE

9 MAR 1944

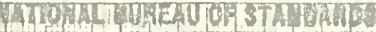

Webriniton Q C

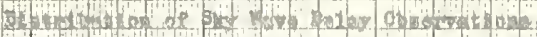

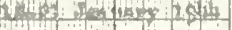

to

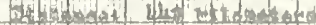

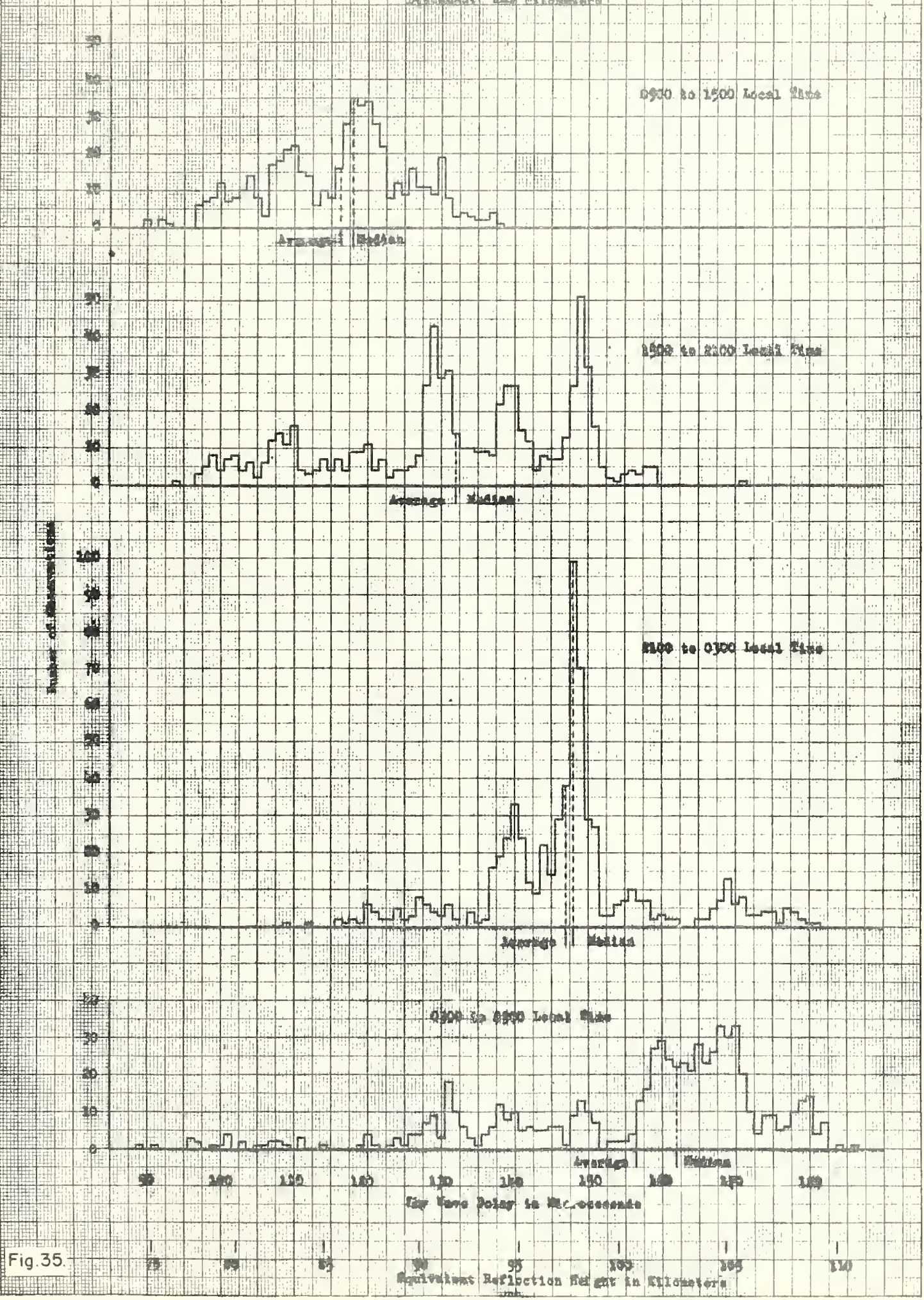




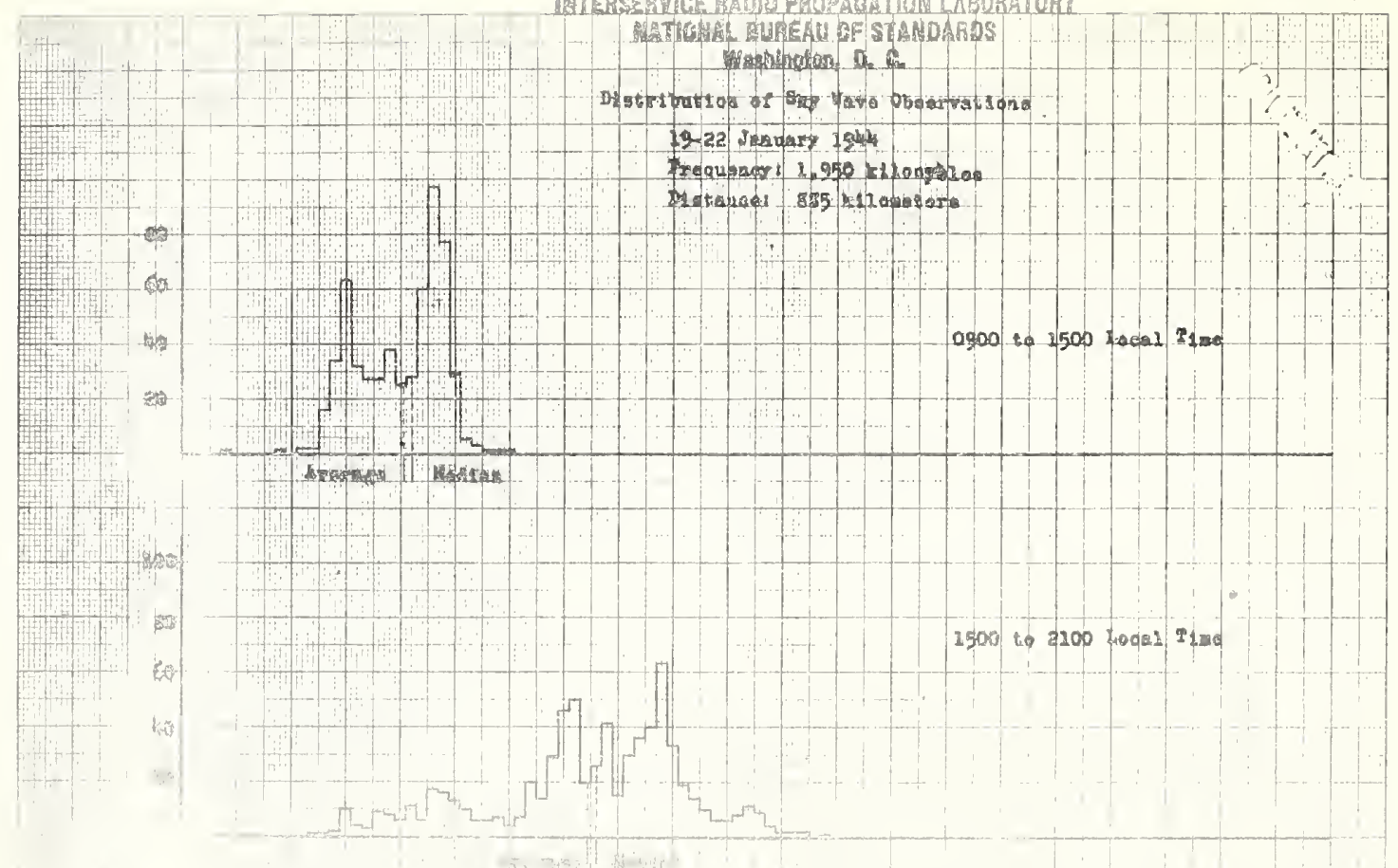

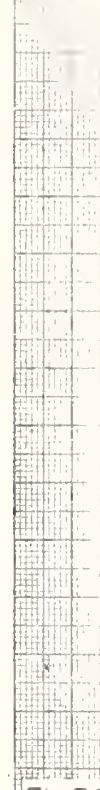

Fig. 36 Hathonotion on

Trequanar i.950 tilonghe

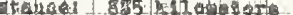

0900 to 1500 todal ?100

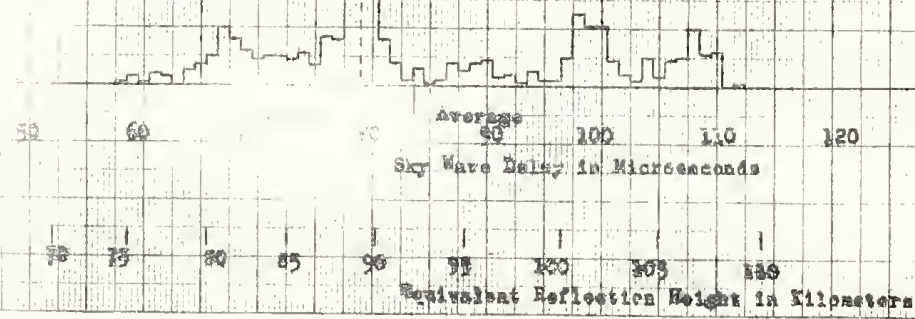




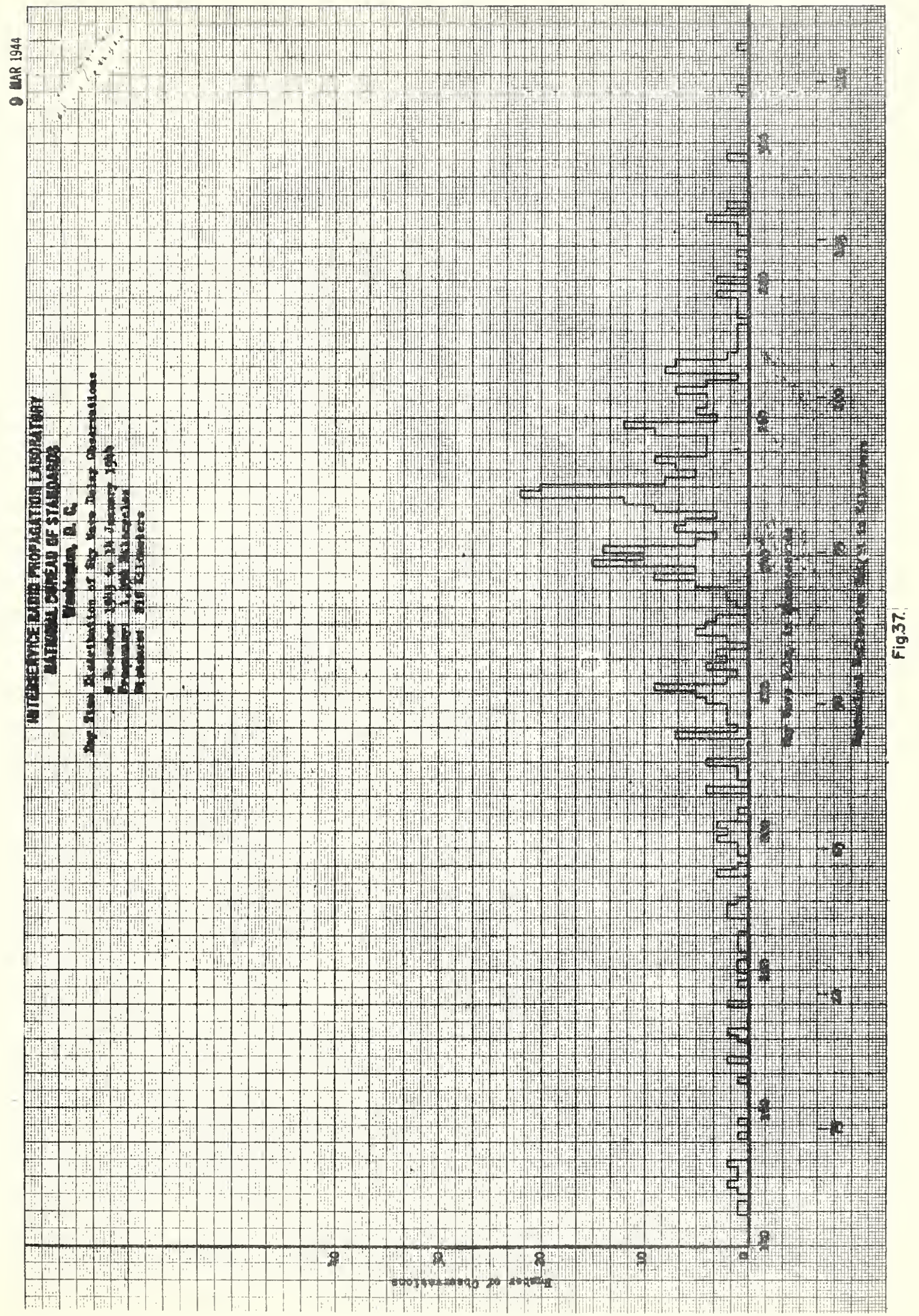




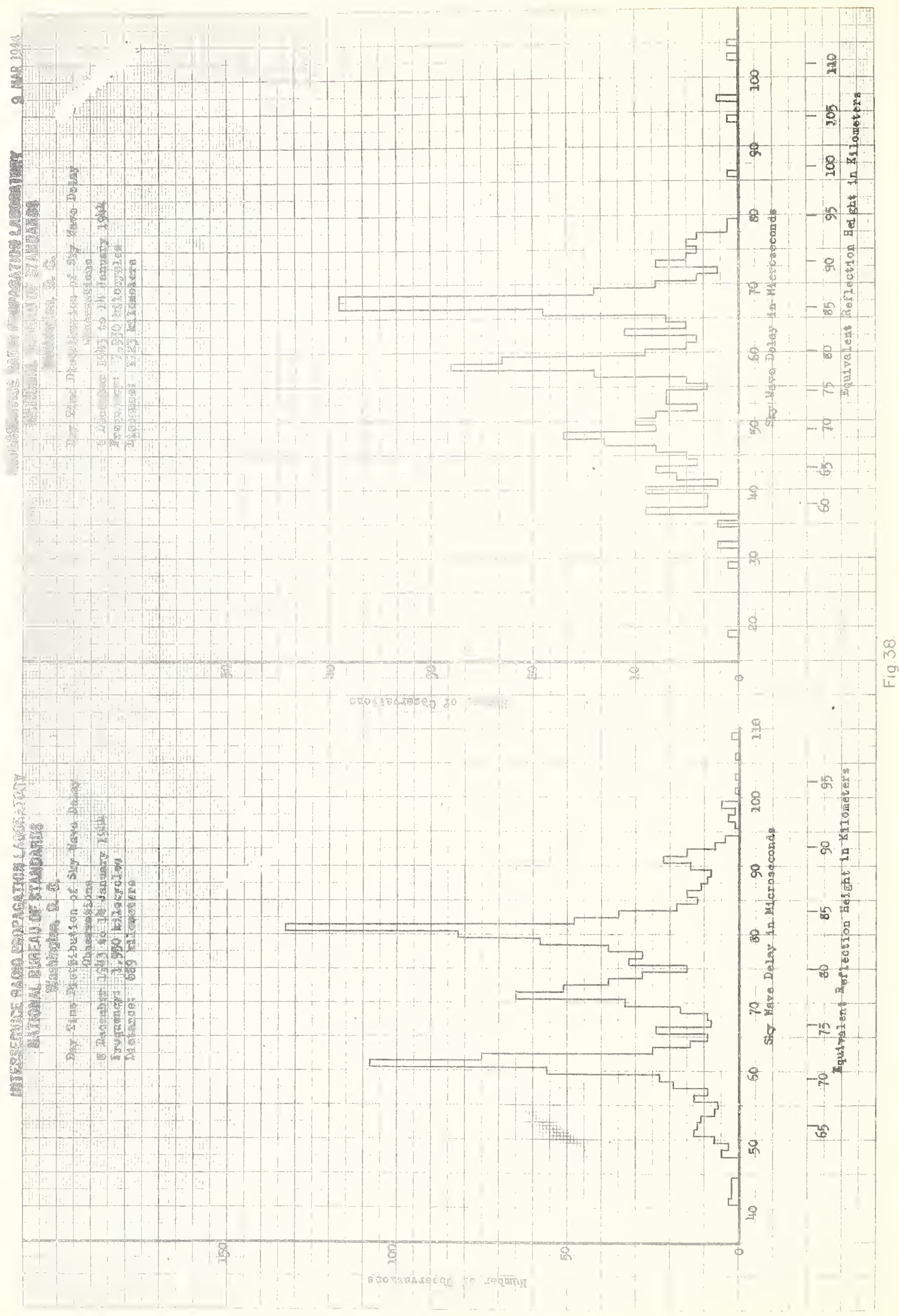




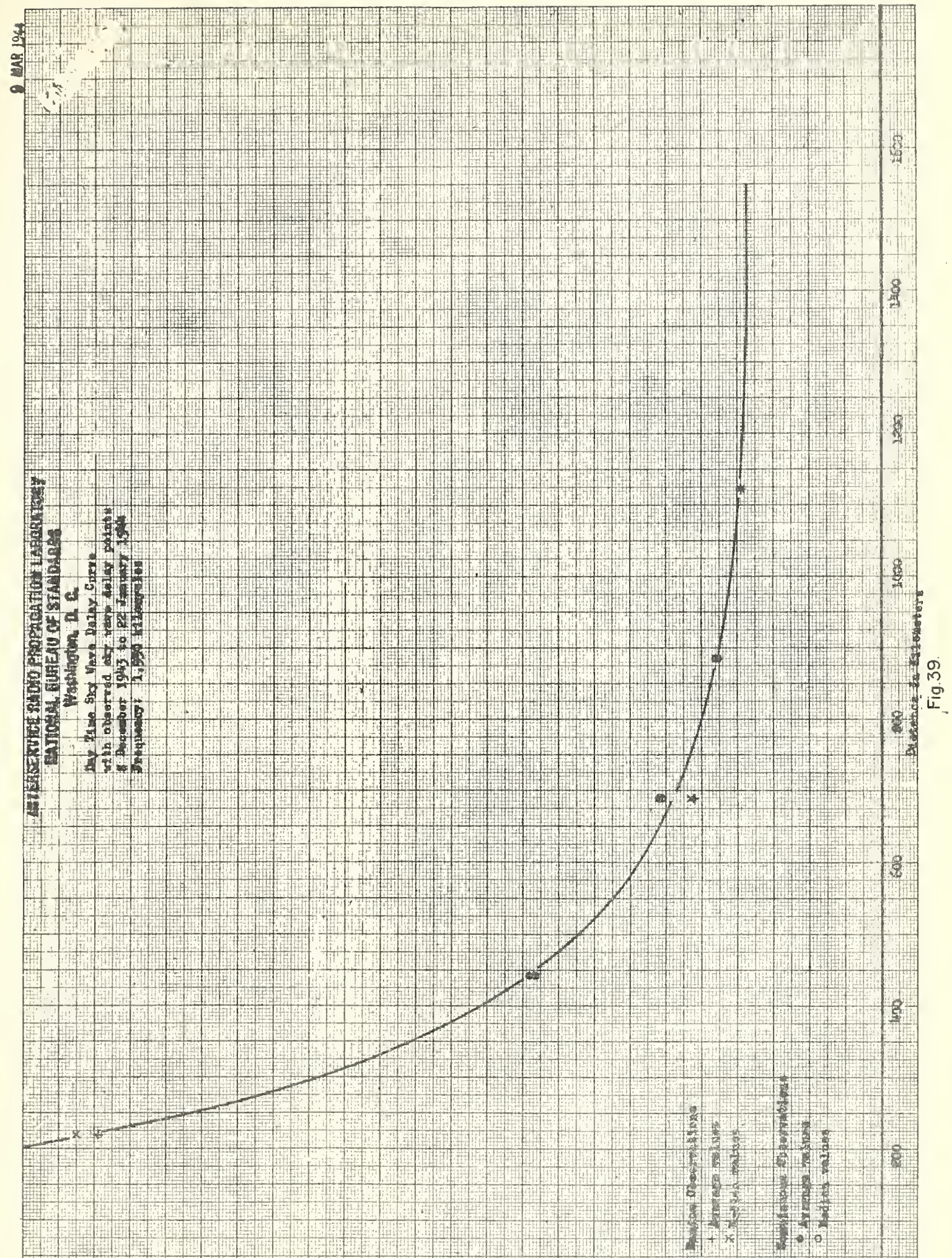




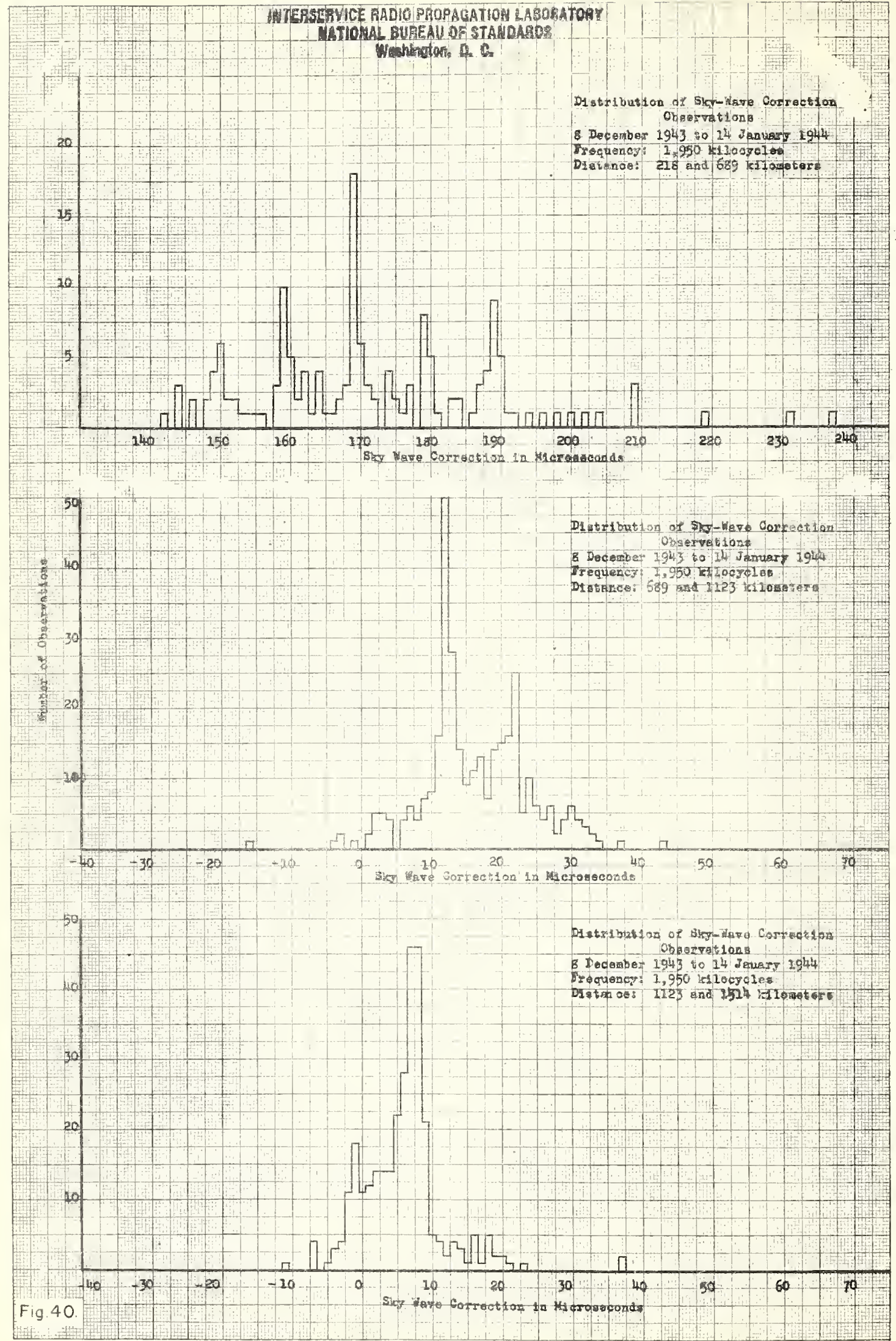


垩

姳

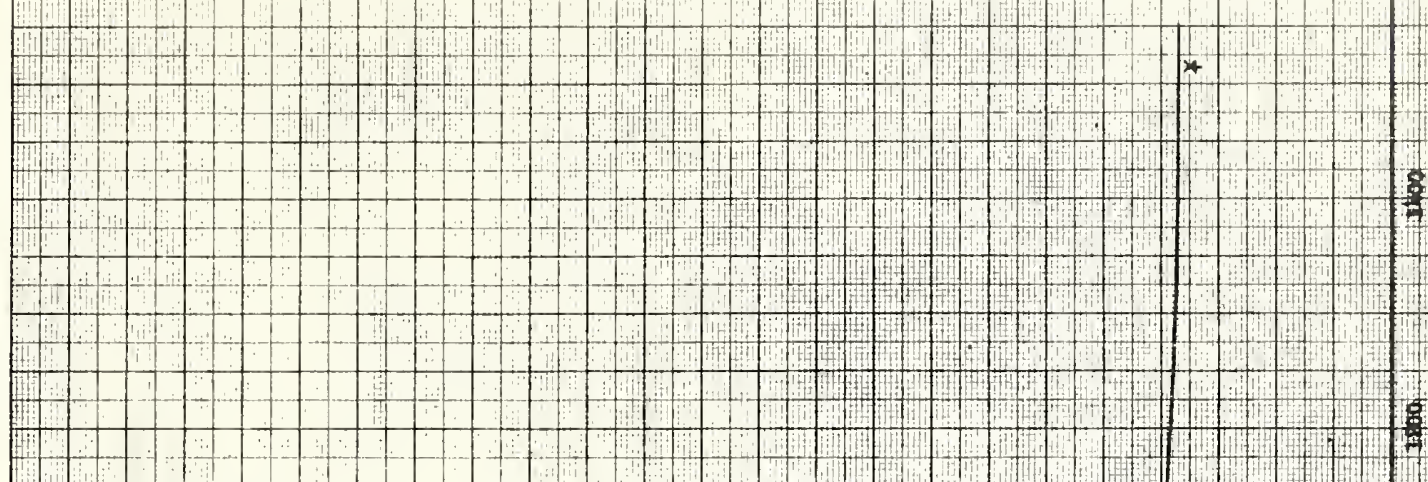

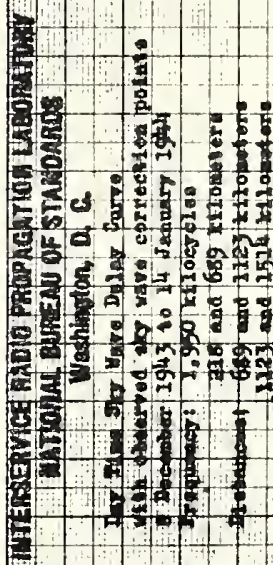

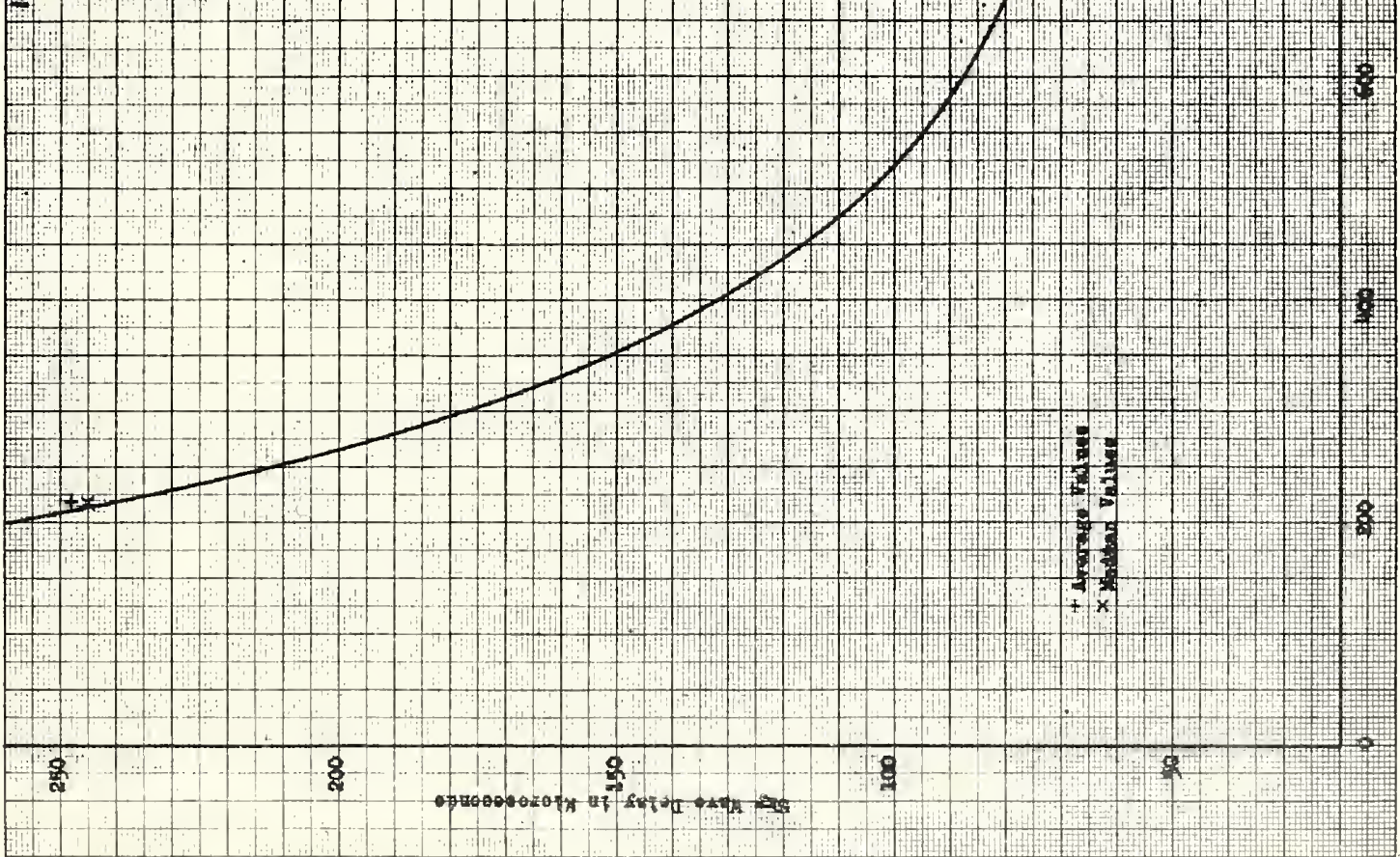





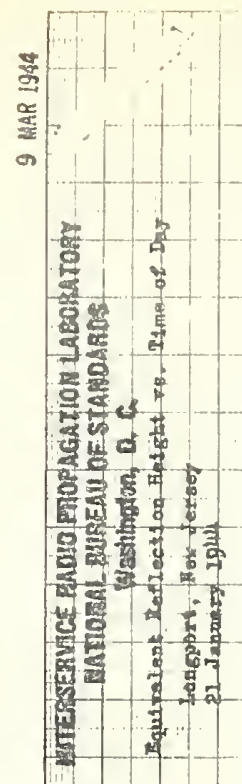

96

$x^{\circ}$ 8

.

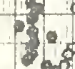

00

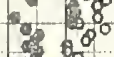
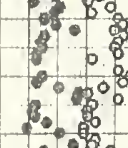

.
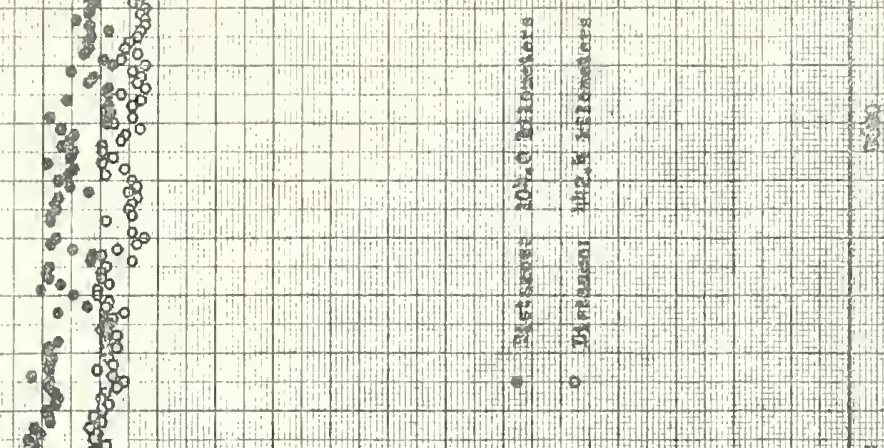

.

to

(8: $8 \%$

露

20 -

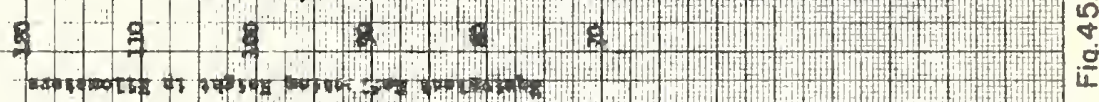

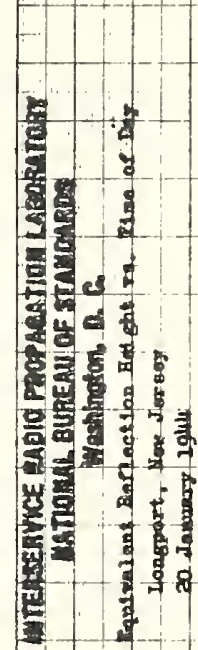

- 1 -

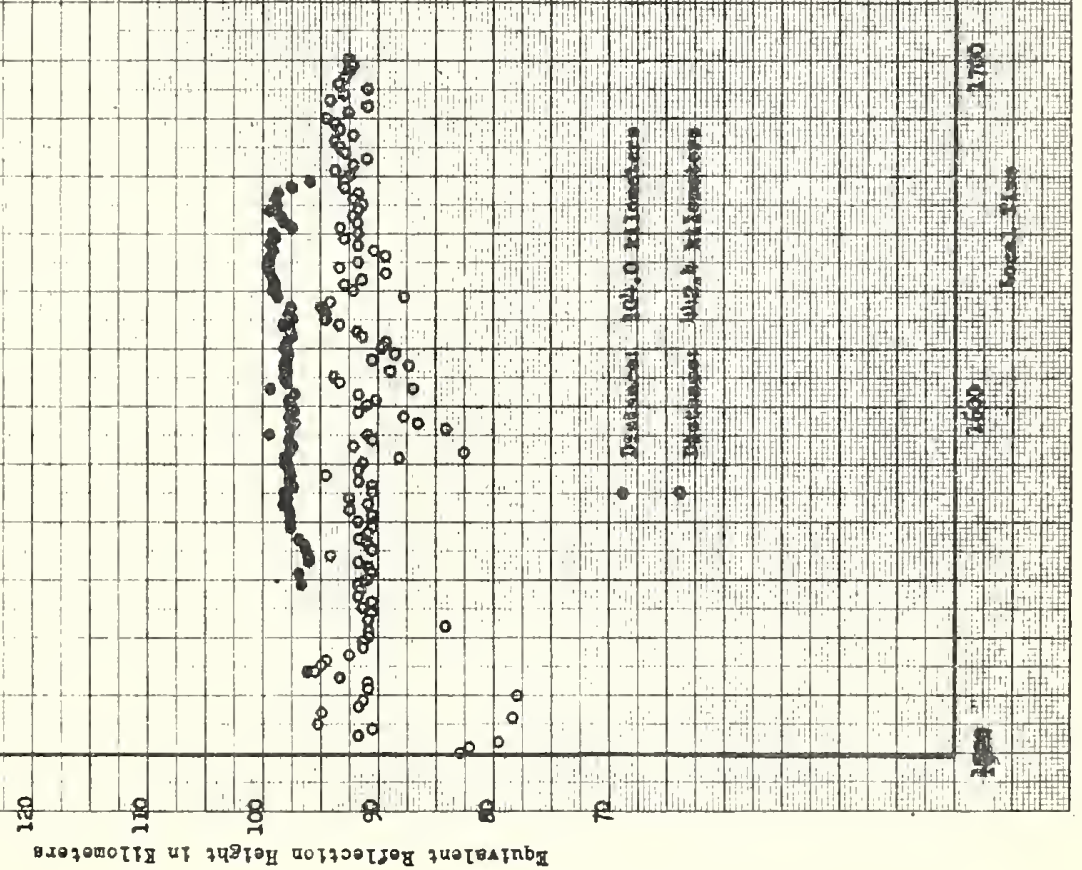



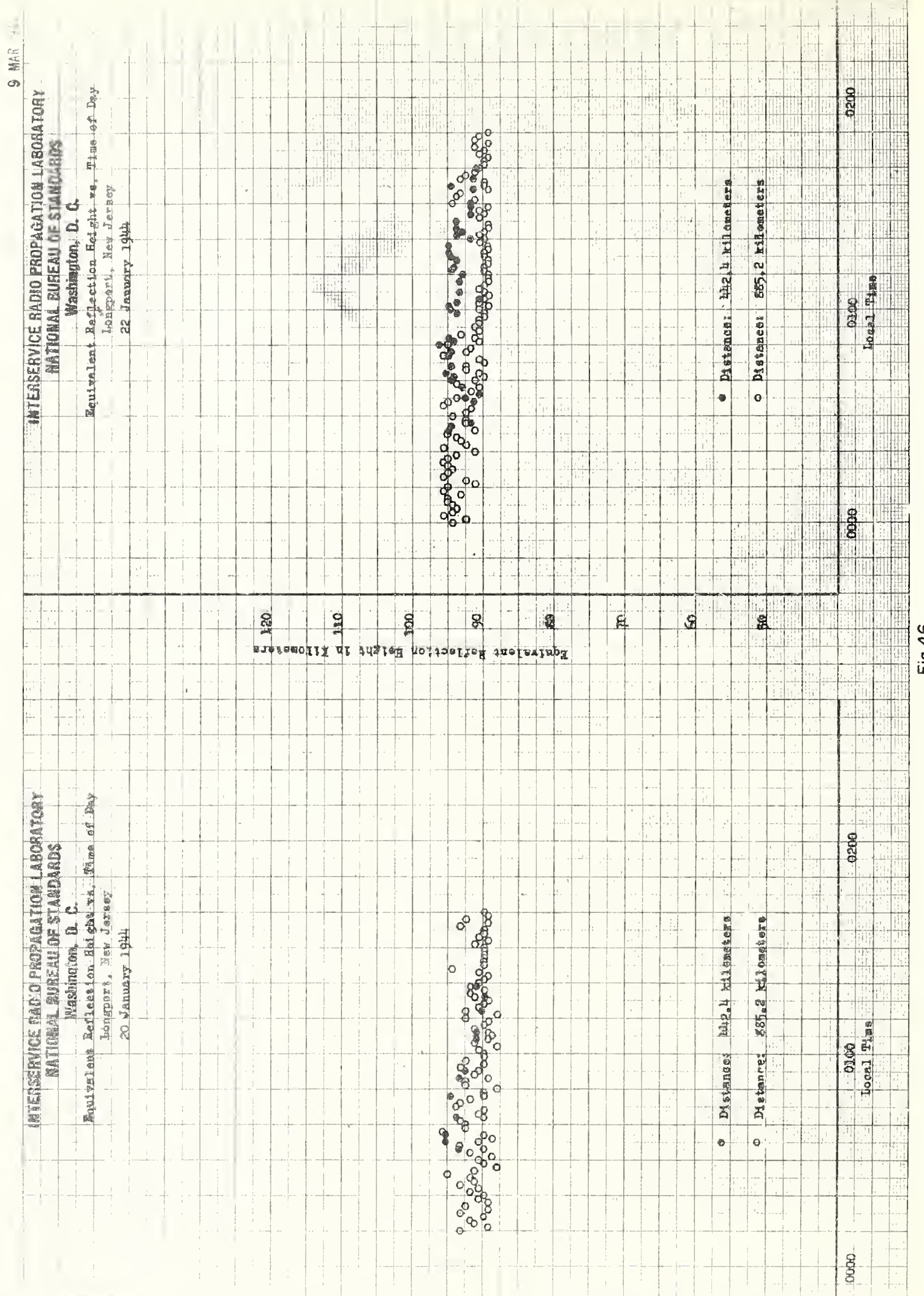

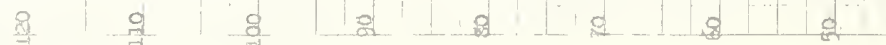




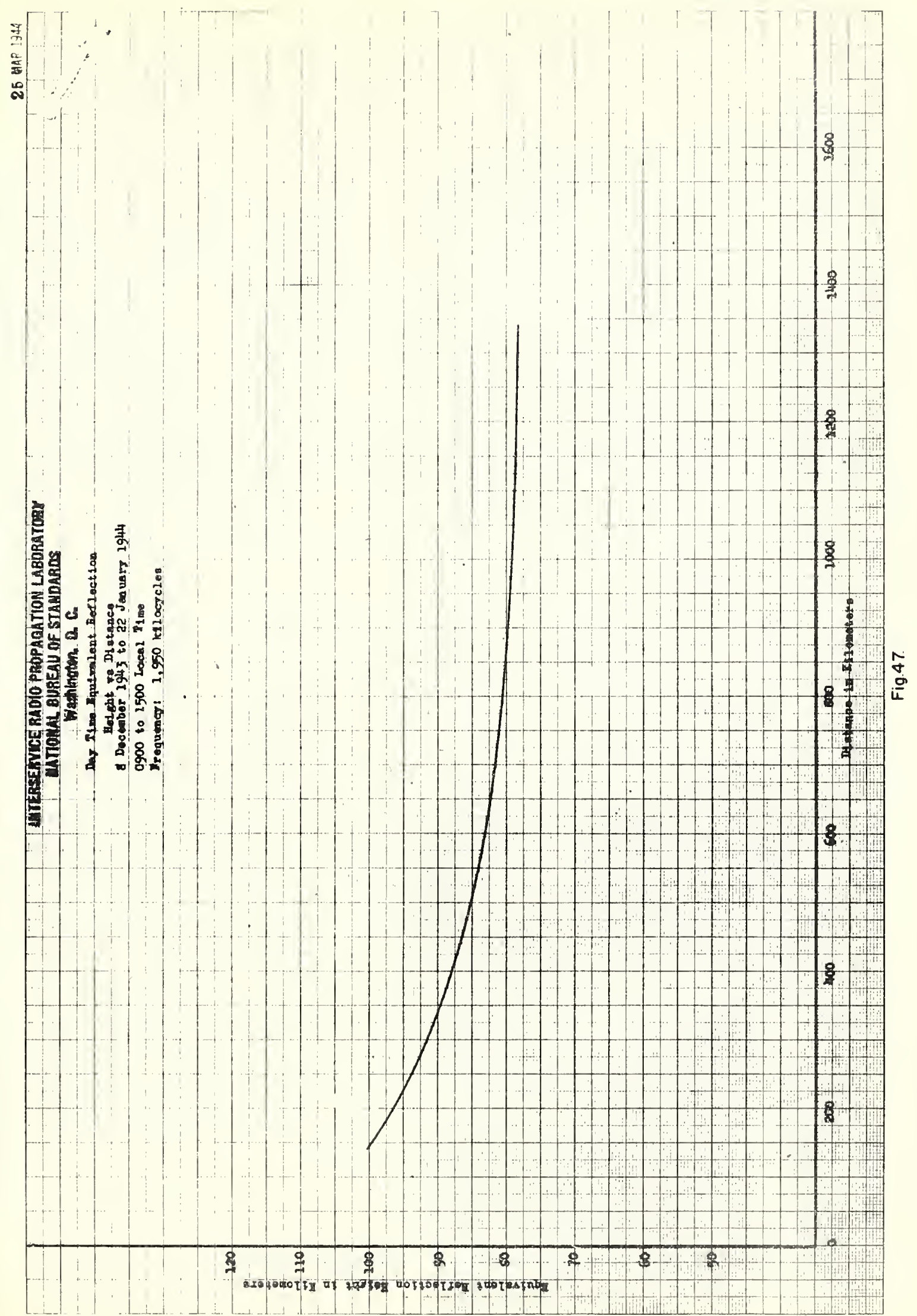




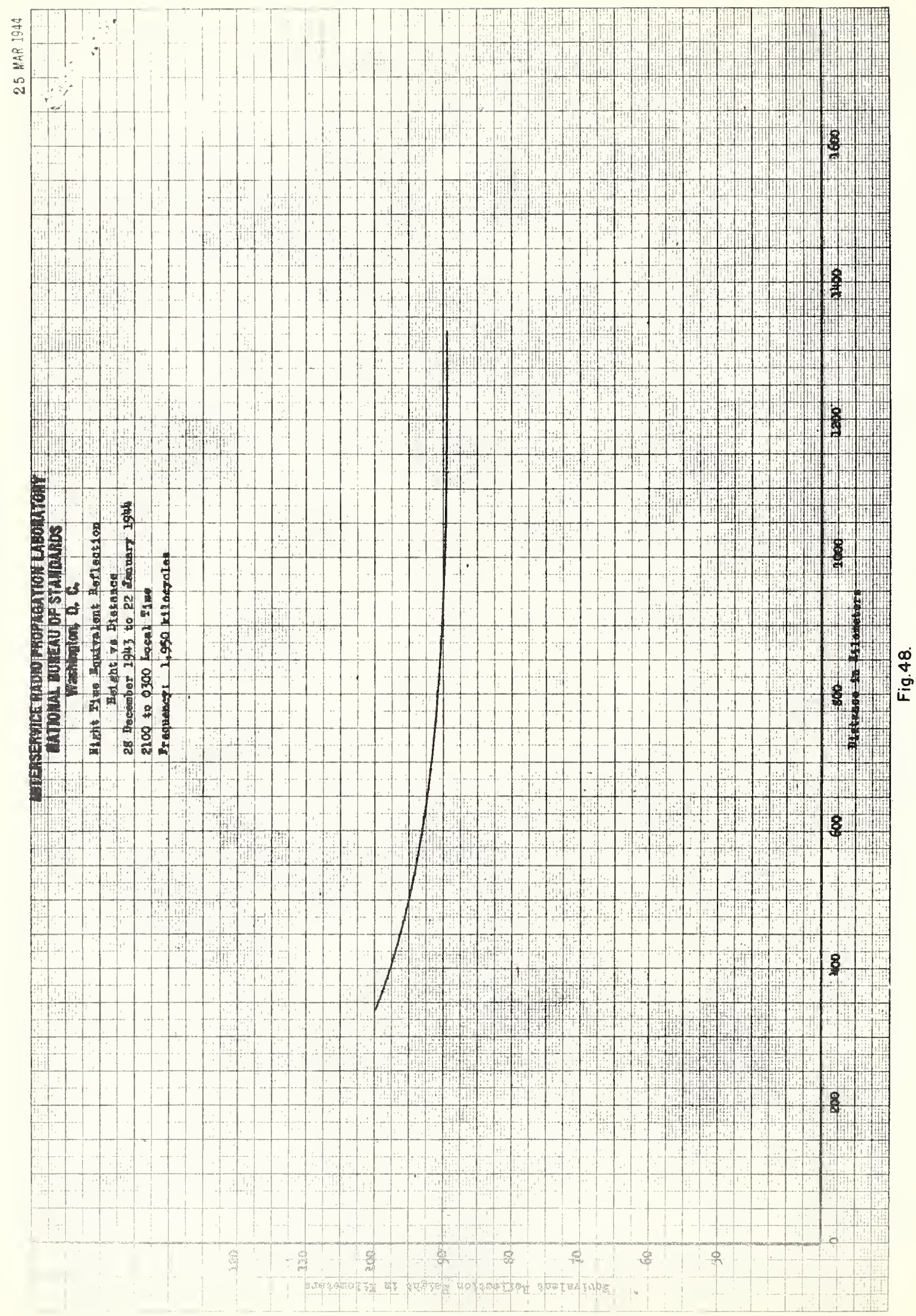




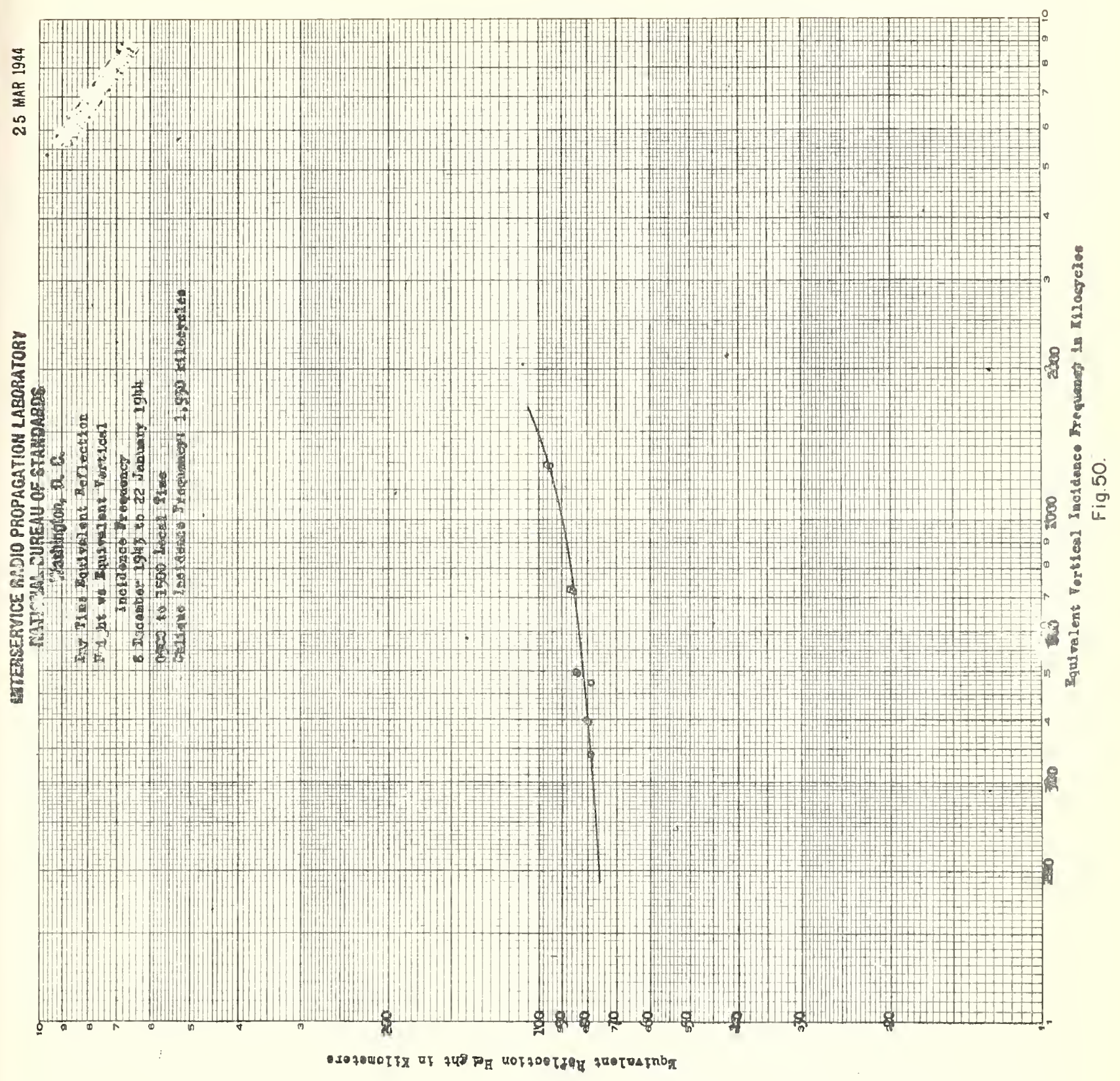




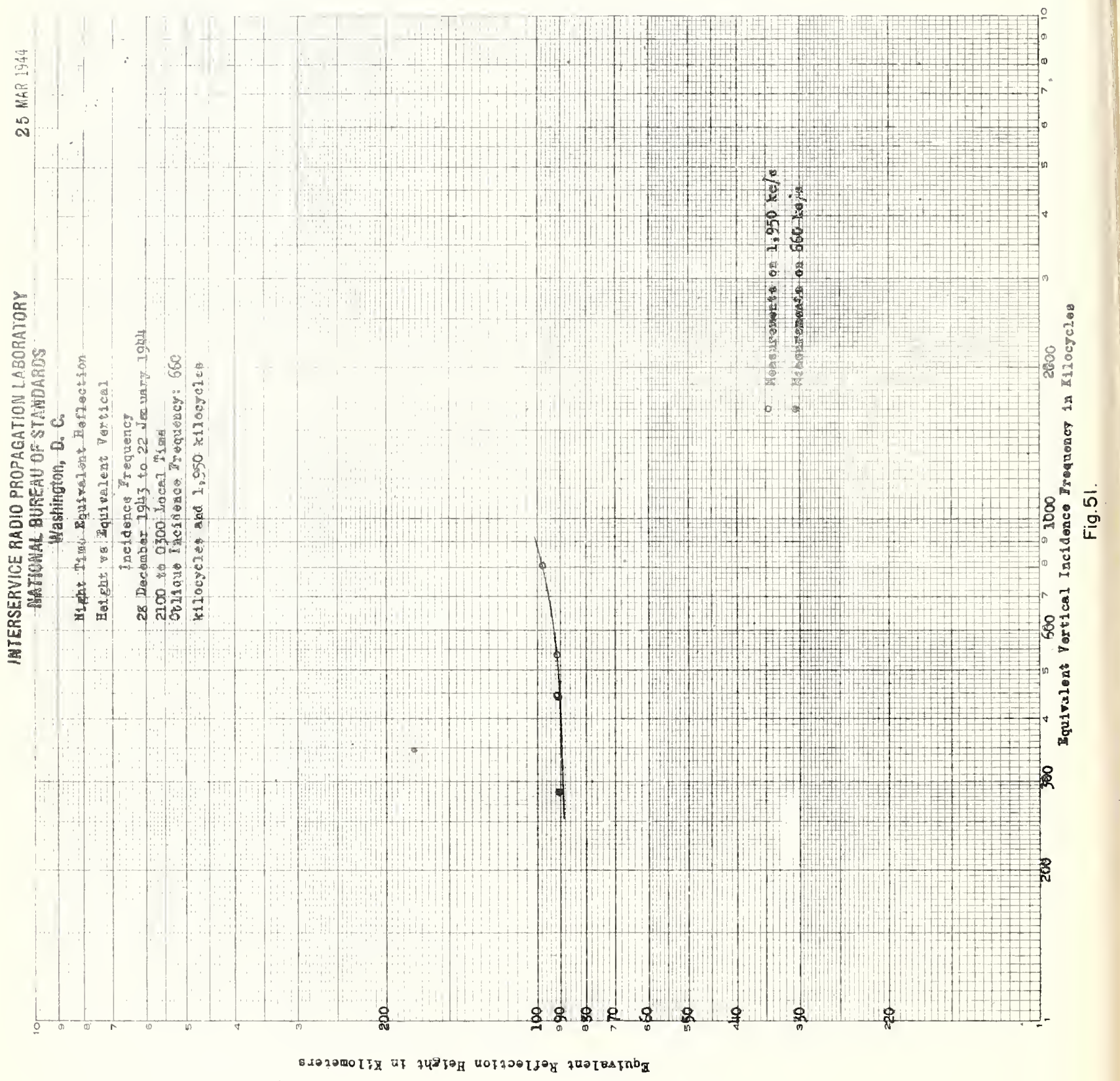



